进ibrary of the attuseum

oF

COMPARATIVE ZOÖLOGY,

AT HaRTaRd COLLEGR, CAIBRIDGr, HaSS.

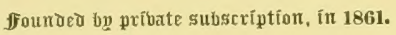

Deposited by ALEX. AGASSIZ.

No. $6405 \mathrm{~A}$.

Recid Sor. 27,187\%. 
. 



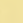



Leach, 'Halacustraca Prowhthalmata Rritanniaa.'

Part Plate dató

I.

2.

3.

4.

5

6.

7.

8.

q.

10.

II.

12

13

14.

15

16.

17.

18,19
$8,14,22$.

$4,15,40$.

$17,28 \%, 28 B$

$19,29,41$.

$23,30$.

$1,2,26$.

$24,36$.

$3, / 2,13$.

$42,7,43$

$6,31,32$.

$9,11,33$.

$2 / A, 2 / B, 5$

18,20 .

$16,25,44$.

$22 B, 3714,378$.

$226,38,39$.

$93,10$. fan. 1, /8/5:

thar. I, 16/5.

Hay $1,1 F / 5$.

ging, 1815:

Sent:1, 18\%.

Hov. 1, 18/.

Can. 1, 18/6.

How. 1, 18/6.

thay $1,1816$.

Guly', 18/6.

Septs, 1816.

How. 1, 18/6.

gave.1, 1817.

Alu. 1, 1817.

guty 1, 18/7.

Dec. 1, 1817.

Haw, 1820.

1875 (20.ty 5. Jomuty). 




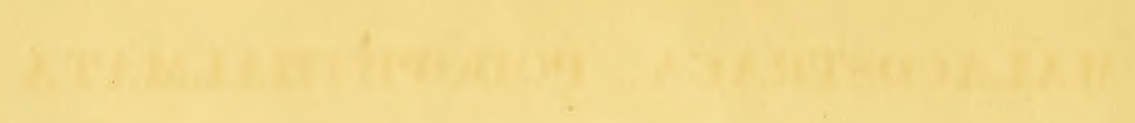

and and

(4) 


\title{
MALACOSTRACA PODOPHTHALMATA
}

\author{
BRITANNIE;
}

OR,

DESCRIPTIONS OF SUCII BRITISII SPECIES OF THE LINNEAN GENUS

\section{Cancer}

AS WAVE THEIR EYES ELEVATED ON FOOTSTALKS.

BY

WILLIAM ELFORD LEACH, M.D. F.L.S. \& W.S.

Fillow of the Royal College of Physiciuns of Edtinburgh; of the Royal College of Surgeons, and of the Medico. Chirurgical Society of London, \&;.

ILLUSTRATED WITH

FIGURES OF ALL THE SPECIES,

BY

JAMES SOWERBY, F.L.S. G.S. \& W.S. \&.

Veniet Tempus quo ista, que nunc latent, in lucem dies extrahet.

Linn.

\section{Lombon:}

PRINTED BY B. MEREdTH, SiLVER STReET, WOOD streEt;

published AND Sold by james sowerby, 2, mead place, lambeth,

1815. 


\section{LIST OF PLATES}

IN THE

\section{A A COSTRACA PODOPHTHALMA.}

\section{New Plates marked thus *}

I.

Corystes cassivelaunus.

II.

Atelecyclus heterodon.

III.

Pirimela denticulata.

IV.

Portumnus variegatus.

V.

Carcinus mœnas.

VI.

Portunus puber.

VII.

Portunus corrugatus, Fig. 1, 2. " emarginatus , 3, 4 .

$"$ arcuatus $\quad, \quad 5,6$.

VIII.

Portunus marmoreus.

IX.

Portunus depurator, Fig. 1, 2.

$"$ lividus " $\mathbf{3}, \mathbf{4}$.

" pusillus ", 5.8.

IX. $a$ *

Portunus longipes, Fig. 1-3.

Thia polita "4.6.

IX. $\mho$.

Polybius Henslowii.

\section{X.}

Cancer pagurus.

\section{II.}

Xantho florida.

XII.

Pilumnus hirtellus.

XIII.

Gonoplax bispinosa.

XIV.

Pinnotheres pisum, Fig. 1-3

" Cranchii " 4, 5 .

$\because \quad$ Latreillei , 6.8.

" varians "9-11.

XV.

Pinnotheres veterum, Fig. 1-5. Montagui , 6-8.

XVI.

Megalopa Montagui, Fig. 1-6.

, armata "7-9.

XVII.

Eurynome aspera.

XVIII.

Maia squinado.

XIX.

Pisa Gibbsi.

$\mathrm{Xx}$.

Pisa tetraodon.

\section{XII. $a$.}

Hyas araneus.

XXI. 6.

Hyas coarctatus.
XXII.

Inachus Dorsettianus, Fig. 1.6. " Dorynchus " 7,8 .

XXII. $b$.

Inachus leptocheirus.

XXII. $c$.

Achæus Cranchii.

XXIII.

Macropodia tenuirostris, Fig. 1-5.

" phalangium , 6 .

$\mathrm{X} X \mathrm{IV}$.

Lithodes maia.

$$
\mathrm{XXIV} a * \text { * }
$$

Dromia Mediterranea.

$\mathrm{X} \times \mathrm{V}$.

Ebalia Pennanti, Fig. 1-6.

"Cranchii , 7-11.

$"$ Bryeri "12, 13.

XXVI.

Pagurue streblonyx, Fig. 1-1.

" Prideauxi " 5, 6 .

XXVII.*

Planes Linnæana, Fig. 1.3.

Porcellana platycheles, Fig. S.

$"$ longicornis "4-7.

XXVIII. $a$.

Galathæa squamifera.

XXVIII. 6 .

Galathæa spinigera.

XXIX.

Galathra rugosa. 
$\mathrm{XXX}$

Palinurus vulgaris.

XXXI.

Gebia stellata, Fig. 1.8.

" deltura $, 9,10$.

XXXII.

Callianassa subterranea.

\section{XXIIII.}

Axius stirynchus.

XXXIV.*

Potamobius astacus, Fig. 1.

Scyllarus arctus

"2-5.

XXXV.

Astacus gammarus.

XXXVI.

Nephrops Norvegicus.
XXXVII. a.

Pontophilus spinosus.

XXXVII. $b$,

Crangon vulgaris.

XXIVII. $c{ }^{*}$.

Crangon fasciatus, Fig. 1.

Alphæus ruber , 2.

Pasiphea sivado "3.

Mysis spinulosus . ", 4-6.

$"$ integer $\quad 7,8$.

XXXVIII.

Hippolyte Prideauxiana, Fig. 1, 3-5.

$\begin{array}{lllr}" & \text { Moorii } & & 2 . \\ " & \text { varians } & \text { " } & 6-16 . \\ " & \text { Cranchii } & & 17-20 . \\ & \text { XXXIX. } & \end{array}$

Hippolyte Sowerbæi.
XI.

Pandalus annulicornis.

XLI.

Processa canaliculata.

XLII.

Pennæus trisulcatus.

XLIII.

Palæmon serratus, Fig. 1-10.

$"$ squilla $" 11-13$.

$"$ varians , 14-16.

XLIV.

Athanas nitescens.

XLV**

Squilla mantis, Fig. 1-3.

"Desmarestii , 4 . 


\section{GENERIC AND SPECIFIC INDEX}

TO TIIE

\section{L A COSTRACA PODOPHTHALMA.}

\begin{tabular}{|c|c|c|}
\hline Actues Cranchii & . & - XXII.c. \\
\hline ALPIIEUS ruber & . & . XXVII. c. 2 \\
\hline AstaCUs gammaruṣ & . & . XXXV. \\
\hline vulgaris & . & . XXXV. \\
\hline marinus & & . $\mathrm{XXXV}$. \\
\hline \multirow{2}{*}{\multicolumn{2}{|c|}{$\begin{array}{l}\text { ATELECTCLUS Heterodon } \\
\text { septemdentatu }\end{array}$}} & . II. \\
\hline & & us . II. \\
\hline ATHANAs nitescens & . & . XLIV. \\
\hline AxIUs styrinchus & . & - XXXIII. \\
\hline CALLTINASSA subterr & ranea & . XXXII. \\
\hline Carcer pagurus & . & . $\bar{X}$. \\
\hline CARCINUs mœnas & . & . V. \\
\hline CoRIstes cassivelaun & & . I. \\
\hline dentata & . & . I. \\
\hline longimane & . & . $\mathrm{I}_{\text {. }}$ \\
\hline personatus & . & . I. \\
\hline Cravgor fasciatus & . & - XXXVII. c. 1 \\
\hline vulgaris & . & - XXXVII. в. \\
\hline Dromia Mediterranea & & . XXIV.a. \\
\hline Rumphii & & . XXIV.a. \\
\hline Batra Bryerii & . & . XXV.12-13 \\
\hline Cranchii & 2 & . XXV.7-11 \\
\hline Pennantii & & . XXV.1.6 \\
\hline tuberosa & . & . XXV.1-6 \\
\hline Eurrnome aspera & . & . XVII. \\
\hline GALATHEd Bamfii & . & - XXIX. \\
\hline longipeda & . & . XXIX. \\
\hline rugosa & . & . XXIX. \\
\hline squamifera & & - XxVIII. a. \\
\hline spinigera. & . & . XXVIII. в. \\
\hline Gebia stellata & . & . XXXI. 1-8 \\
\hline deltura & . & . XXXI. 9, 10 \\
\hline Goroplax bispinosa . & . & . XIII. \\
\hline Hippoltte Cranchii . & - & . XXXVIII. 17-21 \\
\hline Moorii . & . & . XXXVIII. 2 \\
\hline Prideauxiar & & . XXXVIII. 1, 3-5 \\
\hline Sowerbæi . & & . XXXIX. \\
\hline rarians & & · XXXVIII. 6-16 \\
\hline
\end{tabular}

\begin{tabular}{|c|c|c|}
\hline Hras araneus & . & . XXI. A. \\
\hline bufo . & - & - XXI. A. \\
\hline coarctatus & - & . XXI. в. \\
\hline \multirow{2}{*}{\multicolumn{2}{|c|}{$\begin{array}{c}\text { Irachus Dorsettianus } \\
\text { dorynchus }\end{array}$}} & . XXII. 1-6 \\
\hline & . & - XXII, 7, 8 \\
\hline maja & . & . XXIV. \\
\hline scorpio & - & . XXII. 1-6 \\
\hline \multicolumn{2}{|c|}{ leptochierus. } & . XXII. в. \\
\hline \multirow{3}{*}{$\begin{array}{l}\text { LirnoDEs arctica } \\
\qquad \begin{array}{l}\text { horridus } \\
\text { maja }\end{array}\end{array}$} & - & - XXIV. \\
\hline & - & . XXIV. \\
\hline & - & . XXIV. \\
\hline \multirow{3}{*}{\multicolumn{2}{|c|}{$\begin{array}{r}\text { MACRopodta longirostris } \\
\text { phalangium } \\
\text { tenuirostris }\end{array}$}} & - XXIII. 6 \\
\hline & & . XXIII. 6 \\
\hline & & . XXIII. 1.5 \\
\hline \multicolumn{2}{|c|}{ MACROPUS longirostris } & . XXIII. 6 \\
\hline \multicolumn{2}{|l|}{ MaIA squinado } & . XVIII. \\
\hline spinosa. & - & . XVIII. \\
\hline MEGALOPA armata & - & - XVI. 7-9 \\
\hline \multicolumn{2}{|c|}{ Montagui } & . XVI. 1-6 \\
\hline \multicolumn{2}{|c|}{ rhomboidalis } & - XVI. $1-6$ \\
\hline \multicolumn{2}{|l|}{ Mrsis chamaleon } & . XXVII. c. 4-6 \\
\hline integer & - & - XXXVII, c. 7,8 \\
\hline Leachii & - & . XXXVII, c. 4-6 \\
\hline \multicolumn{2}{|l|}{ NepHrops Norvegicus } & . XXXVI. \\
\hline \multicolumn{2}{|l|}{ PaLEMon serratus } & . XLIII. $1-10$ \\
\hline squilla & . & . XLIII. 11-13 \\
\hline varians & . & . XLIII. 14-16 \\
\hline GURUs Bernhardi & - & . XXVI, I-4 \\
\hline Prideauxi & - & - XXVI. 5, 6 \\
\hline streblongx & . & . XXVI, 1-4 \\
\hline NDALUS annulicorn & & . XL. \\
\hline INURUs Homarus & . & . XXX. \\
\hline rulgaris & . & . $\mathrm{XXX}$. \\
\hline PIIEA Savignyi & . & - XXXVII. c. 3 \\
\hline sivado & . & - XXXVII, c. 3 \\
\hline ulcatus & - & . XLII. \\
\hline MNUS hirtellus & & . XII. \\
\hline
\end{tabular}




\begin{tabular}{|c|c|}
\hline \multirow{2}{*}{$\begin{array}{c}\text { Planes Linnæana } \\
\text { minutus }\end{array}$} & . XXVII. 1-3. \\
\hline & . XXVII. 1-3 \\
\hline Prrimera denticulata. & . III. \\
\hline Pinaotilezes Cranchii & . XIV. 4,5 \\
\hline Latreillei & . XIV.6-8 \\
\hline minutus & . XIV.9-11 \\
\hline modioli & . XV. 6-8 \\
\hline Montagui & XV.6.8 \\
\hline mytilorum & . XIV.6.8 \\
\hline pinna . & . XV.1-5 \\
\hline pisum . & . XIV.1-3 \\
\hline varians & XIV.9-11 \\
\hline reterum & XV.1-5 \\
\hline Prsa biaculeata & XIX. \\
\hline gibbsii . & . XIX. \\
\hline tetraodon & . XX. \\
\hline Pourerus Henslowii & . IX. B. \\
\hline Pontophilus spinosus & . XXXVII. A. \\
\hline Potcelitana Leachii . & . XXVII. 4.7 \\
\hline Linnaana & . XXVII. 4.7 \\
\hline longicornis & . XXVII. $4-7$ \\
\hline platycheles & . XXVII. 8 \\
\hline Pontunnos latipes . & . IV. \\
\hline lysianassa & . IV. \\
\hline
\end{tabular}

\begin{tabular}{|c|c|}
\hline PoRTUMNUS variegatus & . IV. \\
\hline Portunus arcuatus & . VII. 5,6 \\
\hline corrugatus & . VII. 1,2 \\
\hline depurator. & . IX. 1,2 \\
\hline omarginatus & . VII. 3,4 \\
\hline lividus & IX, 3,4 \\
\hline longipes & . IX. A. 1 . \\
\hline marmoreus & . VIII. \\
\hline puber . & VI. \\
\hline velutinus & VI. \\
\hline Ротамовids astacus . & . XXXIV. 1 \\
\hline fluviatilis & . XXXIV. 1 \\
\hline Processa canaliculata & . XLI. \\
\hline SCYlLARUs arctus & . XXXIV.2.5 \\
\hline spinulosus & . XXXVII. c. 4.6 \\
\hline vulgaris. & . XXXVII. c. 7,8 \\
\hline SQUILLA Desmarestii & XLV. 4 \\
\hline mantis & . XLV.1-3 \\
\hline THu Blainvillei . & . IX. A. 4-6 \\
\hline polsta . & IX. A. 4-6 \\
\hline residucus & . IX. $\Delta .4-6$ \\
\hline XANTno florida & XI. \\
\hline incisa & . XI \\
\hline
\end{tabular}




\begin{tabular}{|c|c|}
\hline LANes Linneana & . XXVII. 1-3 \\
\hline minutus & . XXVII. 1-3 \\
\hline Prrmela denticulata . & . III. \\
\hline Pinnotmeres Cranchii & . XIV. 4,5 \\
\hline Latreillei & . XIV. 6.8 \\
\hline minutus & . XIV. 9-11 \\
\hline modioli & . XV.6-8 \\
\hline Montagui & . XV.6.8 \\
\hline mytilorum & . XIV. 6-8 \\
\hline pinnce. & . XV. 1.5 \\
\hline pisum. & . XIV.1-3 \\
\hline varians & . XIV.9-11 \\
\hline reterum & XV. 1-5 \\
\hline Pisa biaculeata & . $\mathrm{X \Pi \textrm {r }}$ \\
\hline gibbsii. & . XIX. \\
\hline tetraodon & . $\mathrm{XX}$. \\
\hline Polimius Henslowii & . IX. B. \\
\hline Pontopnitus spinosus & . XXXVII. \\
\hline Porcellana Leachii . & . XXVII. 4.7 \\
\hline Linnaeana & . XXVII. 4-7 \\
\hline longicornis & . XXVII. 4-7 \\
\hline platycheles & . XXVII. 8 \\
\hline Pontrosrast latipes. & . IV. \\
\hline lysianassa & . II. \\
\hline
\end{tabular}

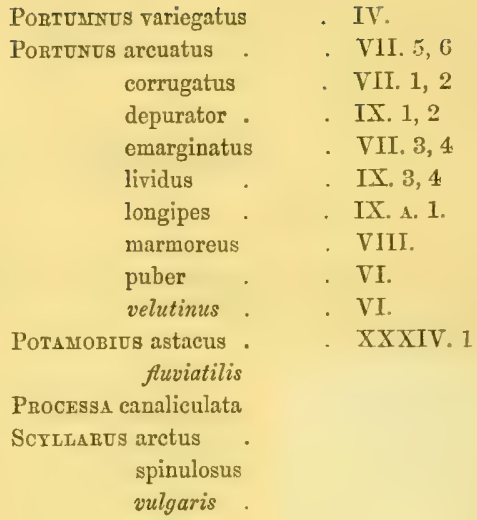

SQuilua Desmarestii . mantis

Тнга Blainvillei polita . residuus

X ANTHO florida incisa 


\section{CORYSTES.}

CORYSTES. Latreille, Leach, Lamarck.

ALBUNEA. Fabricii, Bosc.

CANCER. Pennant, Herbst.

Anteme crtcriores corpore longiores, setacex, utrinque ciliata; segmento tertio ex articulis elongatis, cylindricis efformato.

Pidipalpi gcmini cxterni caulis interni articulo secundo (primo longiore) augusto, apice angustiore rotundato, latere interno latè emarginato.

Pcdes decem: par anticum majus inquale, didactylum, digitis deflexis; marrs corpore duplo longius, subcylindricum, manu gradation subcrassiore, subcompressâ; FEMrN. corporis longitudine manu compressâ: paria reliqua tibiis tarsisque longitudine subxqualibus, unguibus elongatis, rectis, acutis, longitudinalitèr sulcatis instructa.

Abdomen maris 5-articulatum; articulo primo transverso-linèari; secundo longiore utrinque posticè producto; tertio equalitèr subquadrato; quarto præcedente angustiore, transverso ; quinto angustiore, subtriangulari apice rotundato :

FEMINe 7-articulatum; articulis sex primis transversis anticè arcuatis ; septimo trialngulari, apice rotundato.

Testa oblongo-ovata anticè subrostrata, posticè truncata, marginata : orbita supcruè fissurâ unâ. Oculi pedunculo reclivi haud crassiores.

Exterior antenne longer than the body, setaceous, ciliated on cach side: the third segment composed of elongate, cylindric joints. Exterual double fetpalpes, with the second joint of the internal footstalis (longer than the first), narrow, its point more slender and rounded; its internal side broadly notched. Legs ten : anterior pair largest, unequal, didactyle, with deflexed fingers; of the MALE double the length of the body, subcrlindric; the hand gradually somewhat thicker, and subcompressed: of the remaLE the length of the body; hand compressed : other legs with the tibia and tarsi of subequal length: claws elongate, straight, sharp, longitudinally sulcated. Abdomen of the sale five-jointed: first joint transverse-linear; second longer, produced on each side behind; third equally subquadrate; fourth narrower than the third, transverse; fifth narrower, subtriangular; the apex rounded: of the FEMALE seven-jointed; six first joints transverse anteriorly arcuated; seventh triangular, its apex rounded. Shell oblong-ovate, anteriorly subrostrated, behind truncate, margined: orbit above with ore fissure. Eyes not thicker than their peduncles, which bend backward.

One species only of this genus, has hitherto been noticed by naturalists, and of its economy and mode of life nothing is known. 


\section{CORYSTES CASSIVELAUNUS.}

\section{TAB. I.}

C. testâ granulari posticè subcrenulatâ; fronte bifido; lateribus tridentatis

Cancer Cassivelaunus. Penn. Brit. Zool, iv. 6.tab. 7. mas. $c t$ fem.

Herbst. i. 195. tab. 12. fig. 72. mas.

Cancer personatus. Herbst, i. 193. tab. 12. fig. 71 . fem.

Albunea dentata. Fabr. Suppl. Ent. Syst. 398.

Corystes longimane, Latr. Hist. Nat. des Crust et des Insect. vi. 122. mas.

Corystes dentatus. Latr. Gen. Crust. et Insect. i. 40.

Corystes Cassivelaunus. Leach, Edinb. Encyl. vii. 395.

\section{Trans Linn. Soc, xi. 311}

Fig. 1, mas. 2, maris abdomen ampl. 3, Feminæ abdomen auct. 4, Femina. 5, Pedipalpus geminus externus.

On most of the sandy coasts of Great Britain, Corystes Cassivelaunus occurs in great abundance, especially after storms or gales of wind that have been tending towards the shore.

By Herbst the sexes of this animal were considered as distinct species, and Latreille, in the sixth volume of his "Histoire Naturelle des Crustacés et des Insectes," entertained the same opinion, which he has since corrected in his "Genera Crustaccorum et Insectorum." 
Trit: 1.

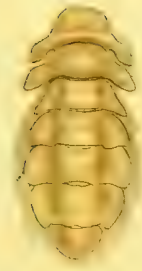

3
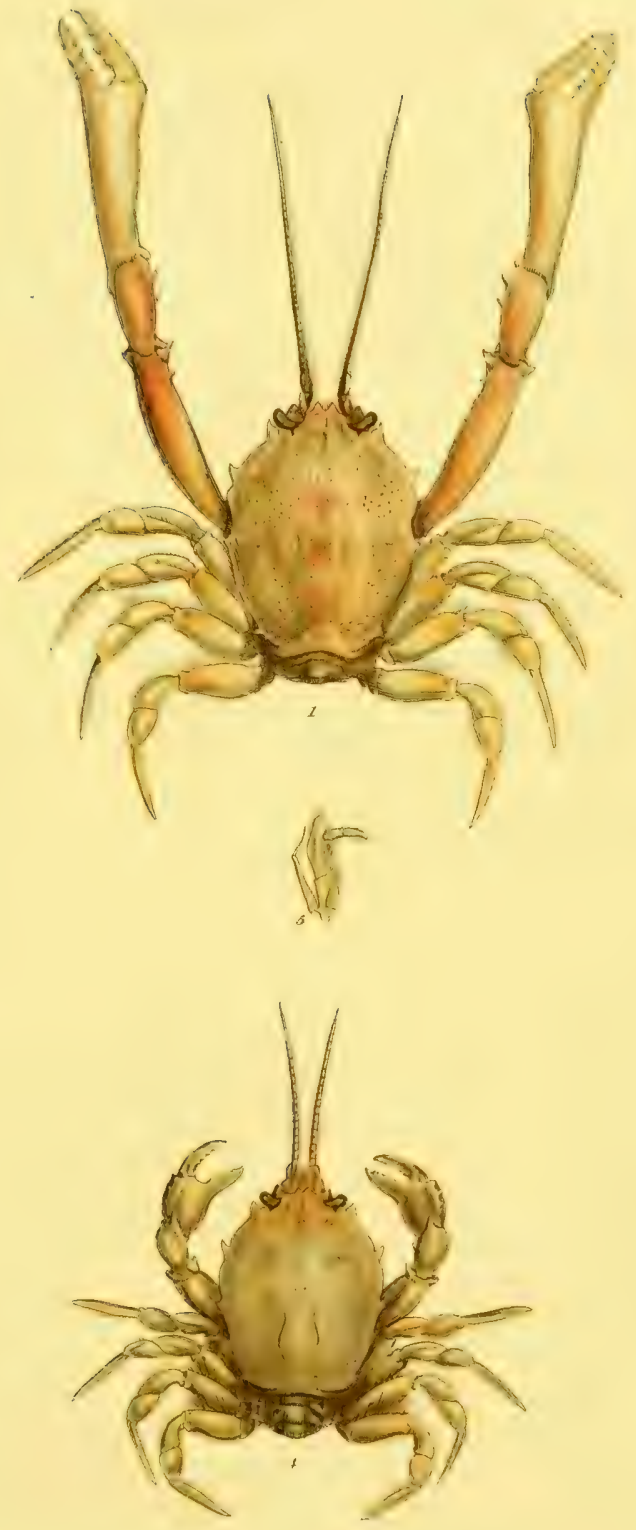

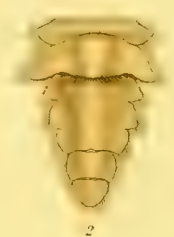





\section{ATELECYCLUS.}

\section{ATELECYCLUS, Leach.}

\section{CANCER (Hippa). Monlagu.}

Antennce extcriores corporis dimidio longiores, setacen, utrinque ciliata; segmento tertio ex articulis elongatis cylindricis effecto.

Pedipaly gemini cxtcrni, caulis interni articulo secundo brevioréad apicem internum producto et ad latus internum apicem versus emarginato.

Pcdes dcccm, par anticum majus, equale, didactylum, digitis deflexis; mar is corpore longius manu compressâ; FEMIN corporis longitudine manu compressâ: paria reliqua tibiis tarsisque longitudine aqualibus, unguibus rectis, elongatis, quadratis, longitudinaliter sulcatis, ad apices teretibus, acutis, nudis (postices obscurè subcompressis.)

Abdomen MARIs 5-articulatum; articulo primo transverso-lineari; secundo duplo longiore; tertio valdè elongato, apicem versus angustiore, apice subrecto; quarto subquadrato, angulis anticis productis; quinto lageniforme, apice acutissimo:

Femre articulis 1, 2, 3, 4 et 5 transversis longitudine vix diversis; articulo sexto transverso-quadrato anticè emarginato; articulo ultimo elongato-subtriangulari posticè subproducto.

Testa subcircularis lateribus sensim posticè in angulum convergentibus posticè truncata et granulari-marginata; orbita posticè externè fissuris duabus, infernè externè fissurâ unâ. Oculi pedunculo angustiores.

Extcrnal antenna longer than half of the body, setaceous, ciliated on each side; the third segment composed of elongate cylindric joints. External double feetpalpes, with the second joint of their internal footstalk shorter than the first, produced at its interior apex, and towards its internal side notched. Leg's ten: anterior pair largest, didactyle; fingers deflexed : of the MALE longer than the body with the hand compressed: of the FEMALE of the length of the body with a compressed hand: other legs with their tibia and tarsi of equal length ; claws straight, elongate, quadrate, longitudinally sulcated; their joints rounded, naked, sharp, hinder ones obscurely subcompressed. Abdomen of the MALE five-jointed: first joint transverse-linear ; second twice as long; third very long, narrower towards its extremity, apex nearly strait; fourth nearly quadrate, the anterior angles produced; fifth flask-shaped, its point very sharp: of the FEMALE with the first five joints transverse and scarcely differing in length; sixth joint transverse-quadrate anteriorly notched; seventh joint elongate-subtriangular, slightly produced behind. Shell subcircular, the sides gradually converging into an angle behind; posterior margin truncate, and granulate-margined; orbit behind externally, with two fissures, below externally, with one fissure. Eyes narrower than their peduncles. 


\section{ATELECYCLUS HETERODON.}

\section{TAB. II.}

A. testa granulata, fronte tridentata, dentibus denticulatis, medio longiore; lateribus dentatis, dentibus inæqualibus margine subdenticulatis; manibus granulatis, granulis nonnullis majoribus in lineis digestis.

Cancer (Hippa) septem-dentatus. Montagu Trans. Limn. Soc. xi. tab. i. fig. i.

Atelecyclus septem-dentatus. Leach Edinb. Encycl. vii, 430.

Trans. Limn. Soc. xi. 313.

Fig. 1, mas. 2, maris abdomen amplif. 3, feminæ abdomen auct. 4, femina. 5, pedipalpus geminus externus.

Zoologists are indebted to the late Montagu for the discovery of this species, which is found in great plenty along the southern coast of Devonshire, in deep water ; and is occasionally also found thrown on the shore after long continued storms.

Females are extremely rare, two full-grown specimens only having been observed amongst several hundreds of the male, and these were found by Mr. C. Prideaux and Mr. J. Cranch.

I have received the young of this species from Mr. Stephenson, of Edinburgh, who obtained them from the Bell Rock.

The legs and arms are beautifully ciliated with testaceous hair, which gives to the animal a very handsome appearance. 


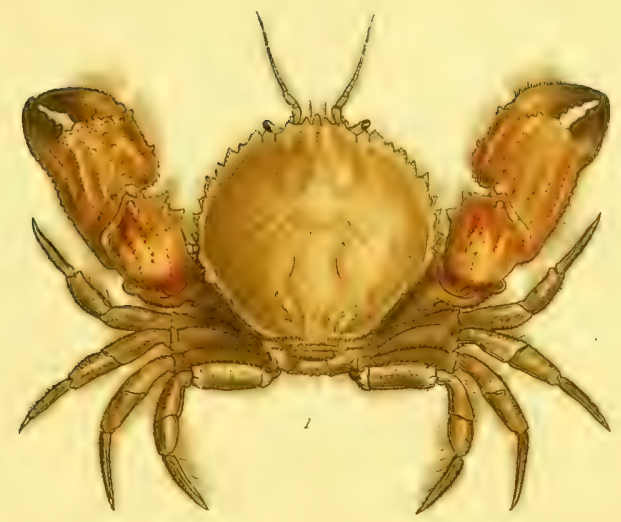

(1)
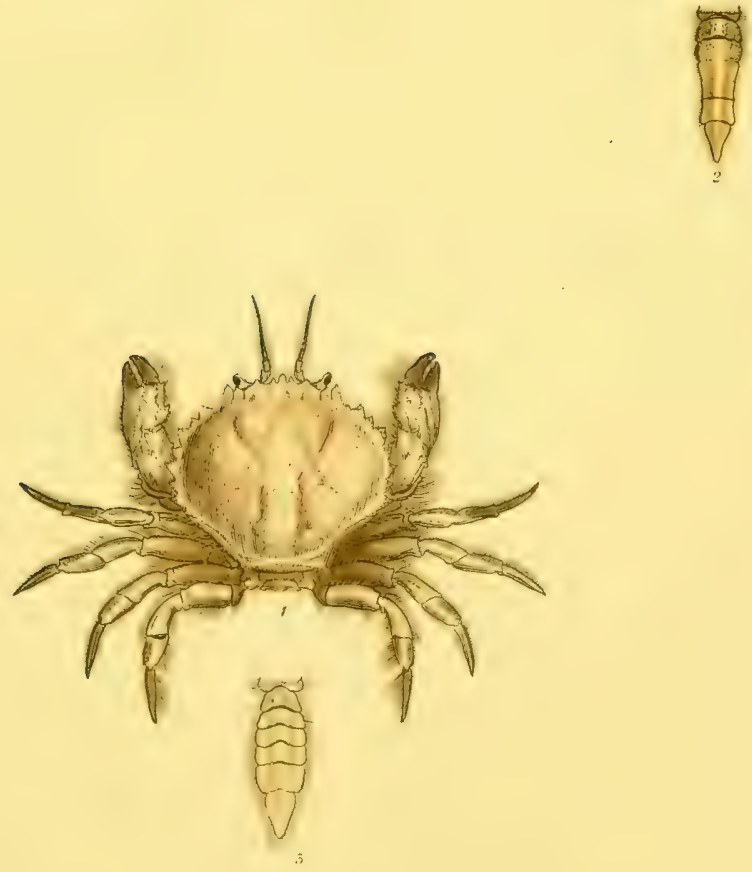



\section{PIRIMELA.}

\section{CANCER, Montrgu.}

Antenne cxternce elongate, setacere ad oculorum canthum internum inserix:

interne in foveolis obliquis reponendx.

Pedipalpi gemini externi cauli interno articulo secundo quadrato, ad apicem internum trunealosubemarginato palpigero.

Pedum par anticum aquale, didactylum ; paria alia ambulatoria, subcompressa : ungues acuti. Abdomen Maris 5, Frmine 7-articulatum.

Testa subtranswersa, margine antico in lineam subsemicircularem arcuato; orbita supra ac: infra fissurâ unicâ.

Oculi pedunculo subcrassiores.

Obs. Mas abdomine articulo quarto quadrato.

External antennæ elongate, setaceous, inserted at the internal corner of the eyes; internal antennæ placed in oblique excavations. External double pedipalpes with the second joint of their internal footstalks, having the internal apex truncate-emarginate for the insertion of the palpes. Anterior pair of legs unequal, didactyle; the other pairs formed for walking, subcompressed; claws sharp. Abdomen of the MALE with five, of the Female with sev enjoints. Shell somewhat transverse, the anterior margin bent in a semicircular line; orbit above and below with one fissure. Eyes somewhat thicker than their peduncles.

This Genus is distinguished from Carcinus, to which it makes the nearest approach, by having the four hinder pair of legs equally compressed, by the greater length of its antennæ, and by the form of the fourth segment of the abdomen of the male. 


\section{PIRIMELA DENTICULATA.}

\section{Tab, III.}

P. testa lævi tuberculata, lateribus utrinque 5̆-dentatis, orbitâ posticè 2-clentatâ; dente anteriore majore, fronte 3 -dentato ; dente medio longiore.

Cancer denticulatus. Montagu Trans. Limn. Soc. ix. 87. Tab. 2. fig. 2.

Leach Edinb. Encycl. vii. 391.

Fig. 1, Mas. 2, Maris abdomen. 3, Femina. 4, Feminæabdomen. 5, Pedipalpus. 6. Antenna externa. 7, Antenna interna.

Montagu first described this beautiful little crab from a specimen sent him from the Sandwich coast, by Mr. Boys.

Donovan has in his Museum a specimen from the Scottish shores, from whence $I$ also have received a fragment. Dead examples were found at Bantham on the South coast of Devon, by C. Prideaux, Esq. who, with his usual liberality, supplied my cabinet with a fine series, exhibiting considerable variation in colour ; but the finest individual that $I$ have seen, and which is figurcd in the adjoining plate, was found amongst the rubbish of some Trawl-fishers, at Torquay, by that accurate observer of nature, Dr. Goodall Provost of Eton, who gave it to me with a number of other marine productions, that now enrich my cabinet. 

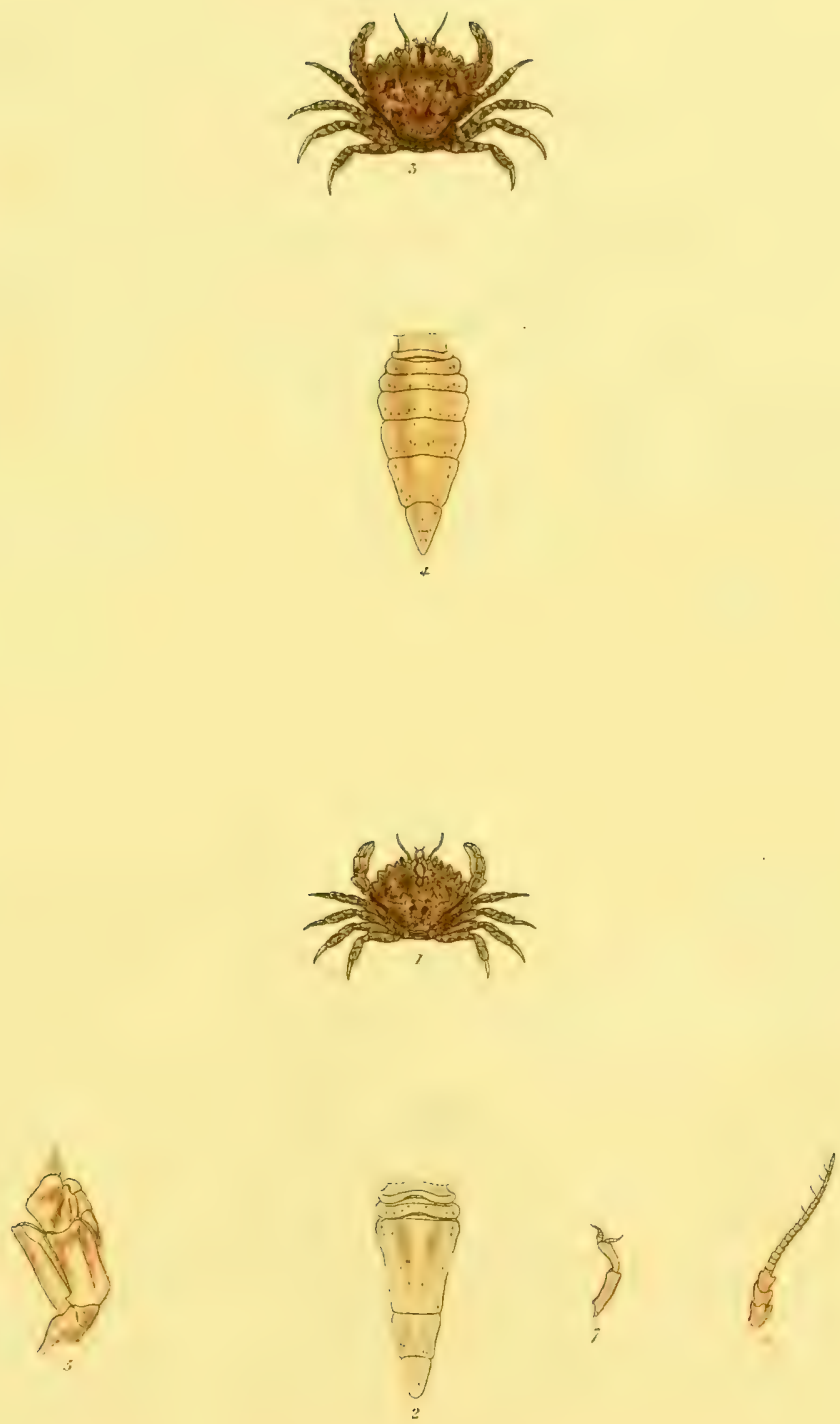



\section{PORTUMNUS.}

\section{CANCER latipes, Planci.}

\section{CANCER, Pennant.}

\section{PORTUMNUS, Leach.}

Antenne cxterne setaceæ articulis duobus primis majoribus, in oculorum cantho interno inserta. Pedipalpi gemini cxtcrni caulis interni articulo secundo ad latus internum emarginato pro insertione palpi triarticulati, elongato-subconici.

$P \varepsilon d u m$ par anticum majus, aquale didactylum; paria 2 , $\mathbf{3}$, et 4 compressa unguibus compressis, sulcatis interneque basin rersus dilatatis instructa; par quintum compressum ungue foliaceo, sublanceolato.

Abdomen Maris 5-articulatum articulis tertio longiore, quarto elongato*: Femina 7 -articulatum articulo ultimo præcedente haud abrupte angustiore.

Teste margo anticus arcuatus, semicircularis lateribus sensim postice in angulum convergentibus, apice subtruncato; diametro longitudinali transversum aquante; orbita integra, angulo interno imperfecto.

Oculi pedunculo mediocri haud crassiores.

External antennæ setaceous, with the two first seginents largest, inserted at the internal corner of the eye. Second joint of the internal footstalk of the external double palpes with the internal side notched for the insertion of the elongate-conic palpes, which are composed of threc joints. Anterior pair of legs largest, didactyle, and equal in size; sccond, third, and fourth pairs compressed, furnished with compressed, longitudinally grooved claws, which are dilated internally towards their base; fifth pair compressed with a foliaceous somewhat-lanceolate claw. Abdonen of the male five-jointed, the third segment longest, the fourth elongate; of the female seven-jointed, the last segment not abruptly narrower than the sivth. Anterior margin of the shell semicircular, with the sides gradually converging to an angle behind; the apex truncate; the transverse diameter not exceding the longitudinal; orbit entire, with the internal angle imperfect. Eyes not thicker than their footstalk, which is short.

The genus Portumnus is distinguished from Portunus by having equal sized fore legs; by having all the claws compressed; by the proportion of the first joint of the abdomen in the male, and the seventh in the female; by the form of the sliell; the entire orbits, and more slender eyes. From the more compressed form of the legs it has cloubtless a much greater facility of swimming in the ocean. 


\section{PORTUMNUS VARIEGATUS.}

\section{Tab. IV.}

P. testa obscure subgranulata, utrinque 5-dentata dentibus 2 et 3 subobsoletioribus; fronte 3-dentata; carpis interne unidentatis.

Cancer latipes variegatus. Planch. de Conch. min. notis. p. 34. tab. III. fig. 7. B. C. mas.

Cancer latipes. Penn. Brit. Zool. IV. p. 3, taib. 1. fig. 4. mas.

Herbst 1. p. 267. tab. XXI. fig. 126.

Cancer Lysianassa. Herbst tab. LIV. fig. 6 ?

Portumnus variegatus. Leach Edin. Encycl. 7.391.

Habitat littora maris passim sub arena latitans.

Fig. 1, mas. 2, maris abdomen. 3, pedipalpus geminus cxternus auctus. 4, antenna externa auct. 5, femina. 6, feminæ abdomen.

Portumnus variegatus is one of the most beautiful as it is the most common species of the Malacostracous animals that inhabit our coasts; it is taken by digging beneath the sand at low water mark, and is found thrown on all the sandy shores of Great Britain in great abundance, especially during storms.

The very fine specimens represented in the annexed plate were given to me by my indefatigable friend, C. Prideaux, Esq. along with a vast number of rare and curious Crustacea, taken by himself on the southern coast of Devonshire. 
:Tाl 2 IT.
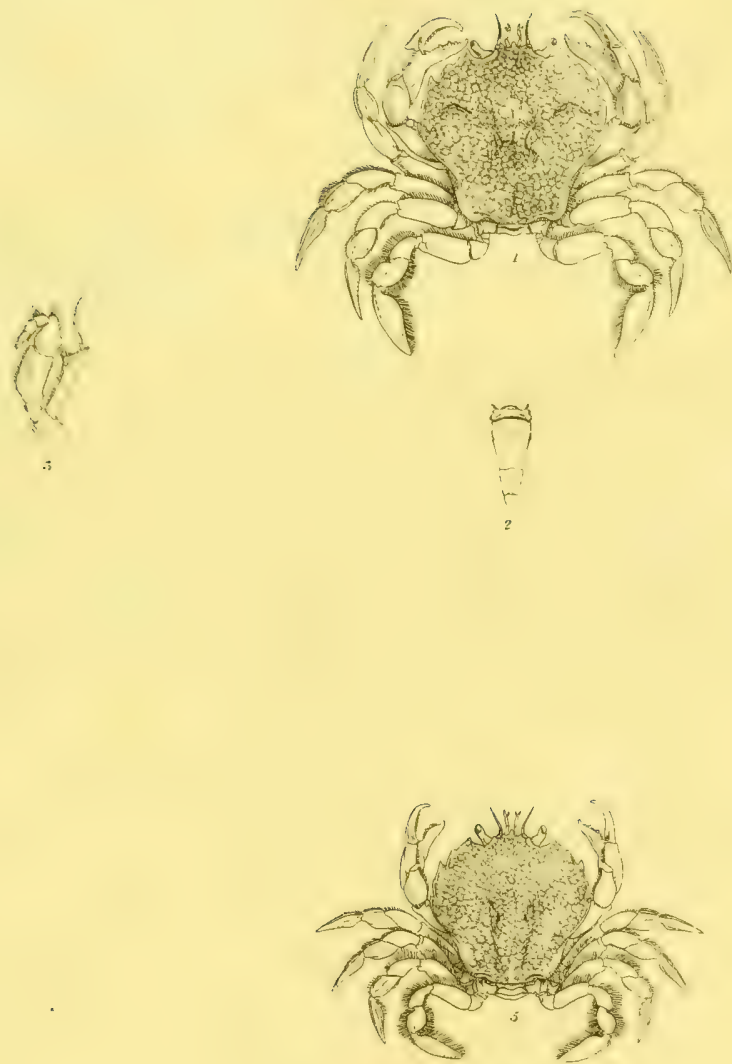

E 



\section{CARCINUS.}

CANCER, Auctorum.

\section{CARCINUS, Leach.}

Antenne cxternce setacea articulis duobus primis majoribus, in oculorum cantho interno inserte. Pedipalpi externi apice interiore truncato-emarginati.

P'edum par anticum inæquale, didactylum, manibus externè glabris : paria 2, 3 et 4 subcompressa, unguibus quadratis longitudinaliter sulcatis: par quintum compressum, subnatatorium, ungue compresso.

Abdomen mans $\mathbf{3}$-articulatum, articulo quarto transverso precedente vix angustiore: Famis. 7-articulatum.

Testa diametro transverso submajore utrinque 5-dentata, margine antico semicirculari, orbitâ posticè et infernè unifissâ, cantho interno imperfecto.

Oculi pedunculo angustiores.

External antenna setaceous, with the two first joints longest, inserted in the internal angle of the orbit. External pedipalpes with their internal apex truncate-emarginate. Anterior pair of legs unequal didactyle, their hands externally smooth; second, third, and fourth pairs slightly compressed, with quadrate claws longitudinally sulcated: fifth pair compressed, with compressed claws. Abdomen of the male five-jointed, the fourth joint transverse, scarcely narrower than the preceding joint; of the female seven-jointed. Shell rather broader than long, with five dentations on each side, the front margin semicircular: orbit behind and beneath with one fissure, the internal canthus imperfect. Eyes narrower than their peduncles.

One species only of this Genus is known. 


\section{CARCINUS MENAS.}

\section{T $\mathrm{AB}, \mathrm{V}$.}

C. testâ granulari, fronte trilobato: lobo medio sublongiore.

Cancer Mænas. Linn. Syst. Nat. xii. 1. 1043.

Fn. Sv. 2026.

Pentn. Brit. Zool. iv. 3. tab. 3, fig. 5.

Fabr. Ent. Syst. ii. 450. 41.-Suppl. 334. 3.

Latr. Gen. Crust. et Insect. i. 30.2.

Portunus Mænas. Leach Edinb. Encycl. vii. 390.

Carcinus Mænas. Leach Edinb. Encycl. vii. 429.

Trans. Linn. Soc, xi. 314.

Encycl. Britann. Suppl. i. 410.

Fig. 1. Carcinus Mænas mas. 2. maris abdomen. 3. fomixa, 4. Focmina abdomen. 5. Antenna externa. 6. Pedipalpus externus. 7. Carcinus Mænas, junior.

This very common species inhabits all the estuaries and rocky shores of Great Britain, lurking beneath stones and tangle or burrowing in the sand. It is sent to London in immense quantities, and is eaten by the poor, who esteem it a great delicacy.

The young or fry, are frequently mottled or bordered with white, and in this state the front of the shell is entire, but this part becomes gradually more lobed as the animal increases in size, and old specimens are rarely found without the rudiments of the lobes.

The colour of the adult is generally similar to that given in the annexed plate, but is sometimes of a pale green more or less mottled with a darker teint, which has probably given rise to the supposition of the existence of several species. 


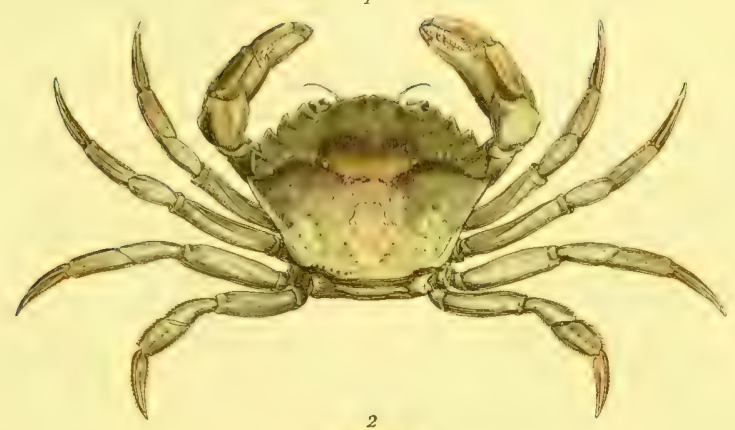

$\frac{6}{?}$
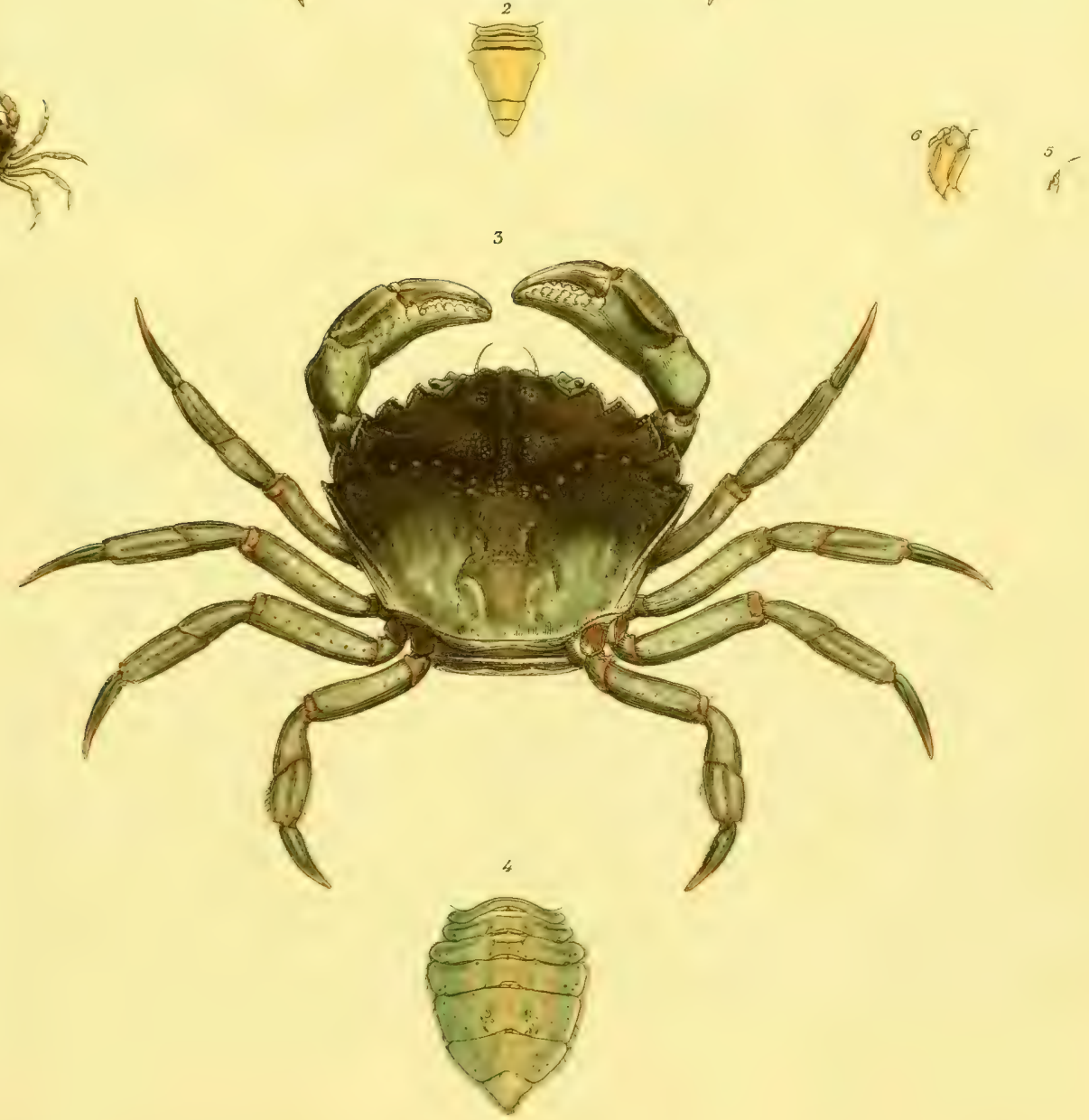


$$
\text { . }
$$




\section{PORTUNLS.}

porTtit's. Dald., Fabr., Lam., Bosc, Lair.

CANCER, Limn., Penn, sic.

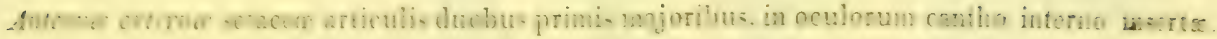

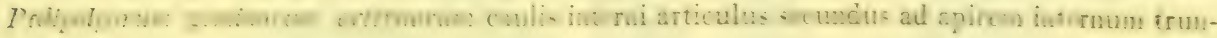
catus, aut ad internum latus enarginatus pro insertione palpi triarticulati, elongatotubconici.

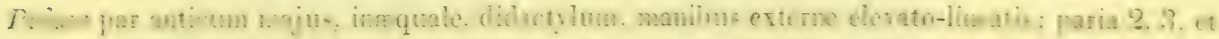

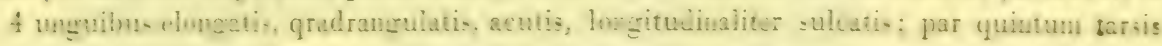
unguibusque foliaceis, natatoriis.

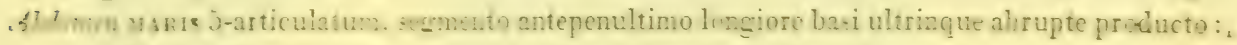
Fevrx 7 -articulatum, articulo ultimo præcedente abrupte angustiore.

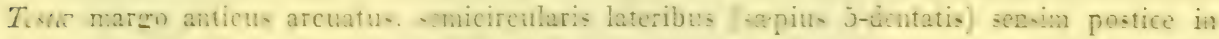

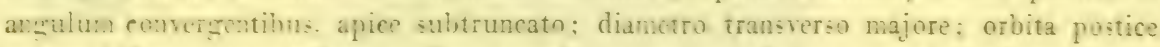

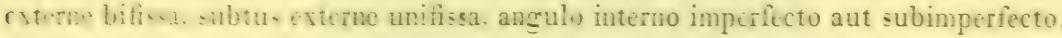

Oculi pedunculo brevi crassiores.

\section{GENERIS DIVISIONES.}

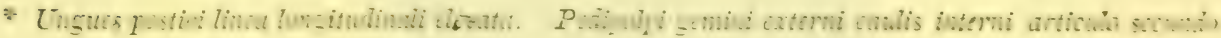
ad apicom internum truncato.

a. Orbita interne ad antennarum insertionem imperfecta; carpi bidentati.

b. Orbita interne subimperficta: carpî unidentati.

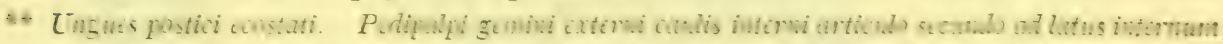

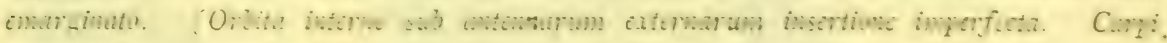
inidentati).

External antenne setaceous, with the two first segments larest. insorted at the internal comer of the eve. Socend joint of the istermal footstalk of the external double pulfes. with the internal apex truncate, or with the internal side rotched for the inserticn of the elongate-conic

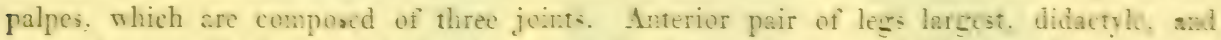
urequal in size, the havis with elevated longitudial lines: the scond, third, and fourth pair with elongate, acute. four-sided longitudiually groned claws: the firth pair with the tarsi and clas a compresed and formed for swimming. Abdemen or thap of the male rive-jumtel, the middle segment logeret with the base on cach side abruptly preduced: ilap of the female seren jointed. the last joint abruptly narrower than the sivli. Anterior margin of the bell semicircular with the siles (armed with five teeth in the indigenous speies) gradwally cunverging into an angle behind, the apex truacate, the transwerse dianeter greate-t: orbit of the eves extormally behind with two fisures. below esicmally with ore fisure, the interal cormor wore or less imperfect. Eres thicher than their footstalk, which is short. 


\section{DIVISIONS OF THE GENUS.}

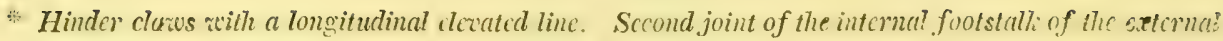
double palpes with the internal apex truncate.

a. Orbit internally at the insertion of the antennce imperfect: vorists bidentate.

b. Orbit internally slightly imperfect: worists unidentate.

** Hinder claw's without an clevated line. Extcrnal double palpes with the scrond joint of inc intonal footstalk notched at the internal side. (Orbit internally, under the inscrition of the cxtirnal antenna, imperfect: wrists with one tooth).

The Portuni, which are commonly named by our Fishermen flying or flat-footed Crabs, have the power of swimming in the occan; they effect this by means of their flat hiuder legs, which serve the purposes of fins. Some of the species, especially those of the first division, frequent rocky coasts, and are to be found at low tide lurking under stones, whilst those of the second division inhabit sandy coasts, approaching the shores only at certain seasons of the year. 



\section{PORTUNUS PUBER.}

\section{TAв. VI.}

P. („. a.) antennis corporis dimidio longioribus, testâ pubescente, fronte multidentato.

Cancer puber. Linn. Syst. Nat. xii. 1046.

Cancer velutinus. Penn. Brit. Zool. iv. 5. Pl.4. fig. 8.

Portunus puber. Latr. Hist. Nat. des Crust. et des Insect. vi. 10.

Gen. Crust. et Insect. i. 27. 3.

Leach Edinb. Encycl. vii. 390.

Trans. Linn. Soc. xi. 315.

Fig. 1. Portunus puber mas, mag. nat. 2. Pedipalpus externus.

Portunus puber is found in great plenty all along the South-Western coast of Devonshire, and is called Velvet Crab by the fishermen. It is used in France as an article of food, and is for that purpose taken in very large quantities. When living the colours are very vivid, as as represented in the plate. 
, 


\section{PORTUNUS CORRUGATUS.}

$$
\text { TAв. VIII.---Fig. 1---2. }
$$

P. (*. b.) testa convexa lineis transversis serrato-granulatis ciliatis utrinque 5-dentata : dentibus tribus posticis acutioribus, fronte trilobo ; lobis subgranulato-serratis; medio majore subacuminato : manibus supra uni-dentatis : unguibus posticis apice acutis.

Cancer corrugatus. Penn. Brit. Zool. iv. 5. Pl. 5. fig. 9.

Herbst. Tab. 7, fig. 50.

Portunus corrugatus. Bosc. Hist. Nat. des crust. i. 217.

Leach Edinb. Encycl. vii. 390.

Trans. Linn. Soc, xi. 315.

Fig. 1. P. corrugatus mas. 2 Pedipalpus.

Pennant discovered this species on the shores of Skie, opposite to Loch Jurn, and 1 have received young specimens from Mr. C. Prideaux, who caught them in the Plymouth Sound.

The fissure in the under part of the orbit is wide; in the two following species the sides of the fissure meet together.

\section{PORTUNUS EMARGINATUS.}

$$
\text { Fig. 3--4. }
$$

P. (. b.) testa convexiore lineis abbreviatis e granulis compositis, dentibus quinque utrinque, penultimo minore; fronte emarginato: manibus supra uni-dentatis: unguibus posticis acutis.

Portunus emarginatus. Leach Edinb. Encycl, vii. 390.

Trans. Linn. Soc. xi. 316.

Fig. 3. Portunus emarginatus. 4. Feminæ abdomen.

This species inhabits the South-IVestern coast of Devon, but is extremely rare. I have once received it from Mr. Gibbs. 


\section{PORTUNUS ARCUATUS.}

Fig. 5---6.

P. (*. b.) testa convexiore lineis abbreviatis e granulis compositis, dentibus utrinque quinque, penultimo minore; fronte arcuato integro; manibus supra uni-dentatis; unguibus posticis acutis.

Portunus arcuatus. Leach Edinb. Encycl. vii. 390.

$$
\text { Trans. Linn. Soc. xi. } 316 .
$$

Fig. 5. Portunus arcuatus. 6. Maris abdomen.

P. arcuatus differs from $\mathbf{P}$. emarginatus only in the form of the anterior part of the shell, and may be no more than a variety of that species. It inhabits the northern and western coasts of England. 

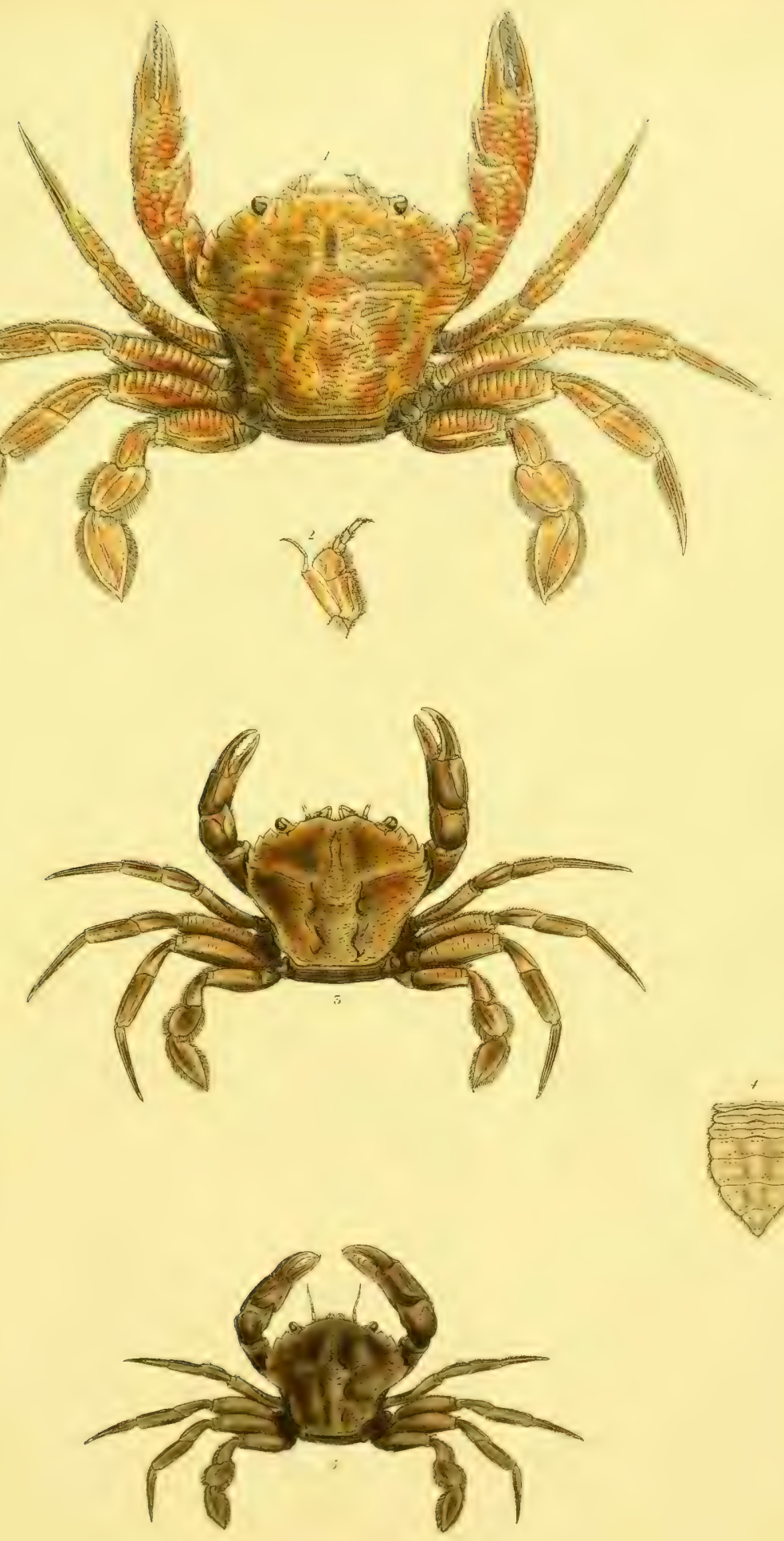




\section{PORTUNUS MARMOREUS.}

\section{Tas. VIII.}

P. (**) Testa conrexa obsolete et tenuiter granulata, utrinque dentibus quinque subæqualibus; fronte dentibus tribus aqualibus, obtusis; manibus glabris lineis obsoletiusculis, supra unidentatis; tarsis posticis apice acutioribus.

Caneer pinnalus marmoreus. Montagu mss.

Fig. 1, mas. 2, maris abdomen. 3, femina, 4, abdomen feminx. 5, pedipalpus externus geminus paululum amplificatus. 6, antenna externa aucta.

\section{MARBLED PORTUNUS.}

Shell conves obsolete and slightly granulated, with five nearly equal sized teeth on each side; front with three equal, obtuse teeth; hands smooth with obsolete lines, above unidentate; hinder tarsi with their points acute: color whitish clegantly marbled with reddish.

This very beautiful species, which derives its name from its color, was discovered by G. Montagu, Esq. who very kindly sent me spccimens for description. It is not uncommon on the sandy shores of the Southern coast of Devon, from Torcross to the mouth of the river Ex, and is frequently found entangled in the shore rets of the Fishermen, or thrown on the shore after heavy gales of wind.

The rounded form of the dentations between the eyes, the very slight elevation of the lines on the liands, the convexity, remarkable smoothness and marbled appearance of the shell, at once distinguish this from any other species of the genus with which I an acquainted.

Young speciniens are plain brown, and much resemble the fry of Portunus depurator, from whlich they may be easily separated by their more considerable convexity.

Full-grown specimens are subject to some variation in color and markings, as may be seen in the amexed plate, where the two extremes are depicted. The second and third joint of the abdomen is in both sezes transverscly carinated. 

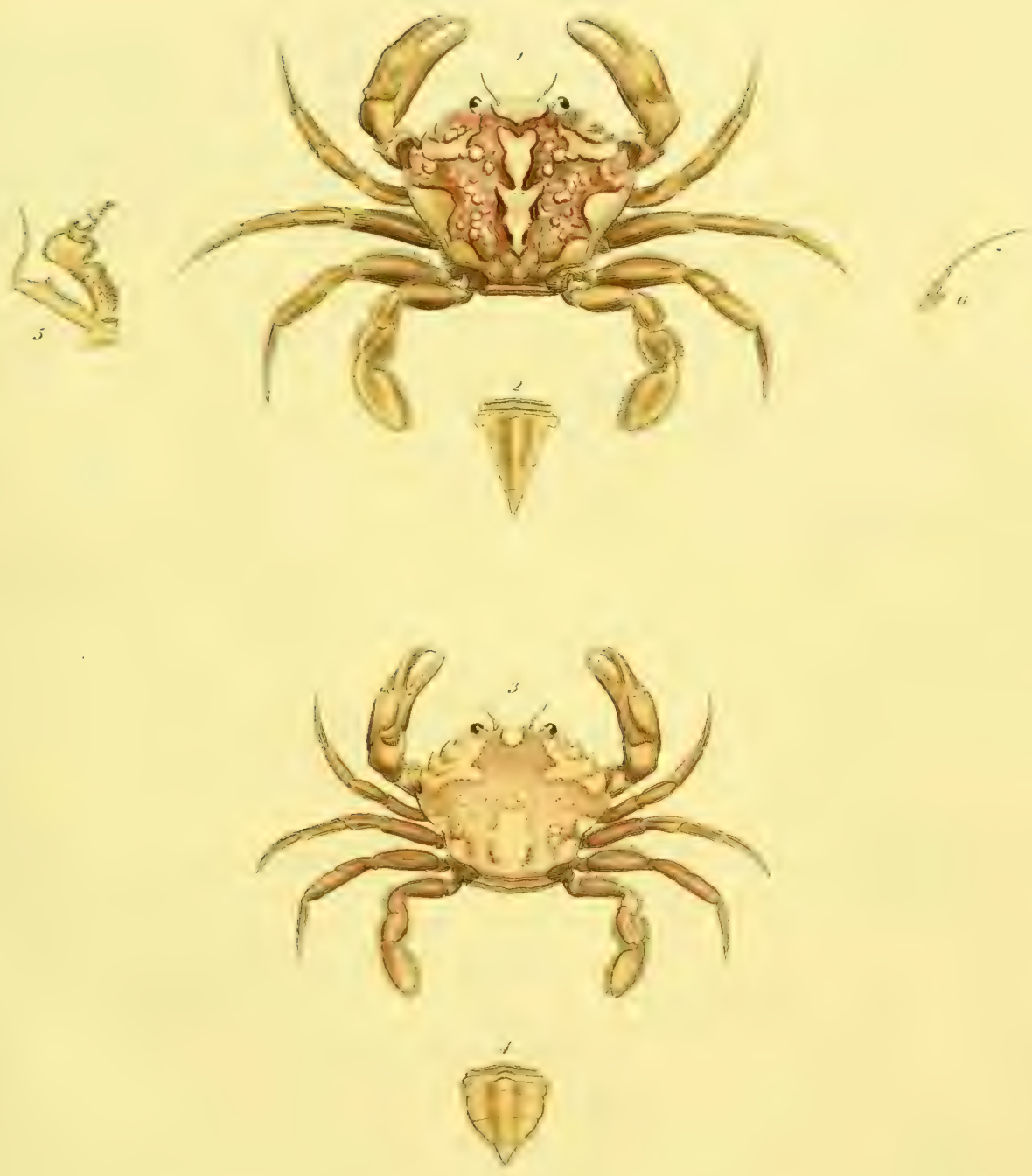


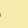




\title{
PORTUNUS DEPURATOR.
}

\author{
'ҮАв. IX.--Fig. 1---2.
}

P. (**) testa subcomplanatî lincis elevatis et transwersis abbreviatis e granulis compositis, utrinque dentibus quinque: secundo breviore: postico subremotiore: fronte dentibus tribus: medio subacutiore sublonginre, manibus supra unidentatis, tarsis posticis apice acutioribus sæpè subemarginatis.

Cancer depurator. Linn. Syst. Nat. xii. 1043. 23.

Cancer depurator, var. Penn. Brit. zool. iv. tab. 4. fig. 6. A.

Portunus depurator. Fabr. Suppl. Ent. Syst. 365. 9.

Leach Edinb. Encycl. vii. 390.

Trans. Linn. Soc. xi. 3I7.

Fig. 1. Portunus depurator mas mag. nat. 2. Maris abdomen.

The sculpture of the shell of $P$. depurator, which is by far the most common species that inhabits the British Coast, raries considerably in degree. The second and third joints of the abdomen of both sexes (especially of the male) are acutely carinated transversely. The ahdomen of the male is triangular; of the female broad; the cilia which surround it being very long, the third, fourth, fifth, and sixth joints are broader than the two first: sides of the sixth acute; the seventh abruptly narrower than the one before it.

It is often eaten by the poor of London.

\section{PORTUNUS LIVIDUS.}

$$
\text { Fig. 3---4. }
$$

P. (**.) testâ complanatâ tenuè subg̨ranulatî utrinque dentỉus quinqque : secundo subbreviore: postico remotiore, fronte dentilus tribus acutis: medio longiore, manibus supra unidentatis, tarsis posticis apice abruptè productis.

Cancer depurator. Penn. Brit. Zool. iv. tab. 2. fig. 6.

Portunus lividus. Leach Edinb. Encycl. vii. 390.

Trans, Limn. Soc, xi. 317.

Fig. 3. Portunus lividus Mas. 4. Maris abdomen.

This species most reseinbles $P$. depurator, from which it differs in having the shell narrotrer behind, with the surface minutely granulated, the eyes too are smalier and the antennæ shorter.

I found a single specimen amongst a number of the preceding species that were taken in the Frith of Forth, at Newhaven, and observed another in the collection of Nontagu. 


\section{PORTUNUS PUSILLUS.}

Fig. 5---8.

P. (**.) testâ subrugosâ, fronte productâ trilobâ, lateribus 5-dentatis : dente postico acutiore. Portunus pusillus. Leach Trans, Linn. Soc. xi. 318.

Fig. 5. Portunus pusillus mas. 6. maris abdomen. 7. femina. 8. femine abdomen.

This beautiful little species is found occasionally in the Frith of Forth ; and is very common in some parts of the southern coast of Devon, where it is taken by dredging in deep water.

The fingers are generally annulated with red and whitish, and the back is not unfrequently ornamented with a red streak or spot. 

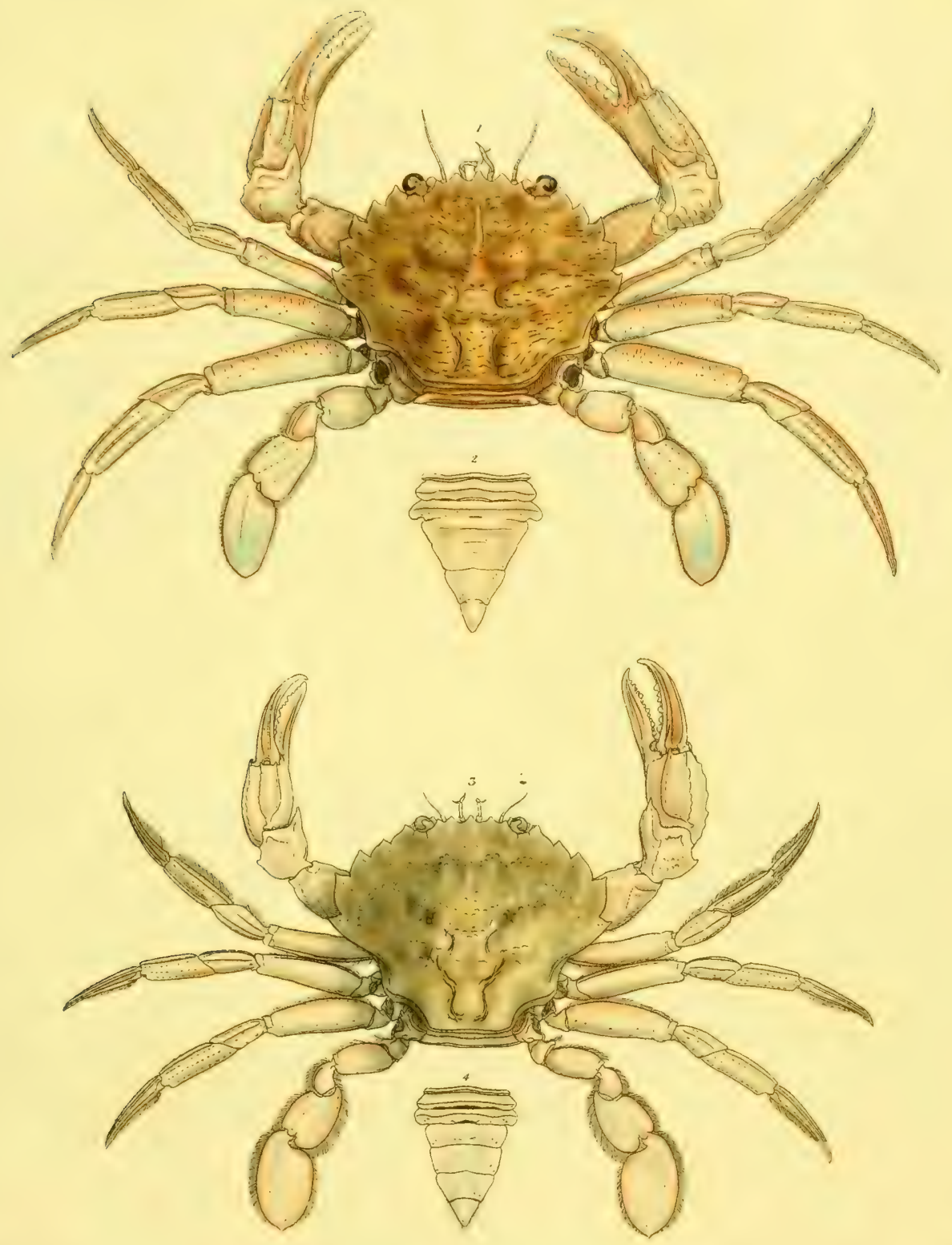
- 


\section{PORTUNUS LONGIPES.}

\section{TaB. 1X. a. Fig. 1.}

P. testa transversè subquadrata, margine antico-laterali quam posticum breviori, fronte quadrilnbata ; dentibus marginalibus acutis; postico elerato, acutissime producto; pedibus angrnstielongatis.

Portunus longipes. Risso, Crust. Nice, t. 1, fig. 5.

Fig. 1. Portunus longipes, mas. mag. nat. 2. Pedipalpus. 3. Femina abdomen.

This species is more slender in all its parts than any others of the genus. The front of the carapace is wide and short, with five teeth on each side, the last of which is much produced. Like many other crustacea long known as ILediterranean, this Portunus has been tardily discorered ats an inhabitant of our shores.

\section{THIA.}

\section{THIA, Leach.}

\section{CANCER, Linnæus.}

Antenna externæ subtus occuli pedunculum instructæ.

Pedipulpi rersus foream antennarum extensi, articulo superiori magis lato çnam longro.

Oculi minuti, pedunculis brevissimis.

Testa cordata, posticè angustata, lateraliter arcuata.

Pedum par anticum breve, unguibus deflexis.

Abdomen utroque sexu angusto.

External antenne pliced beneath the peduncle of the eye. Pedipalps extended towards the antemal pit, with upper joint lrootder than long: Eyes rery minute, with short peduncles. Carapace heart-shaped, narrow posteriorly, arched from side to side. Anterior pair of feet short, with the fingers bent downwards. Abdomen narrow in both sexes.

\section{THIA POLITA. \\ FIG. 4-6.}

T. testa polita, valde arcuata, margine obsoletissime dentato, ad oculum unisulcato, postice angustissimo, ad terminum truncato, omnino cilinto, orbitis minutissinis, oculis ferè obtectis. 
Pedum pari antico robusto, unguibus incurvis leviter tuberculatis, paribus alteris brevibus complanatis; ultimo brevissimo. Abdomine feminæ septem-articulato.

Thia polita. Leach, Zool. Misc. II. tab. CIII.

Cancer residuus. Herbst. 1. t. XLVIII. fig. 1.

Thia Blainvillei. Risso.

Fig. 3, Thia polita, mas. 5, Maris abdomen. 5, manus. 
Sablit
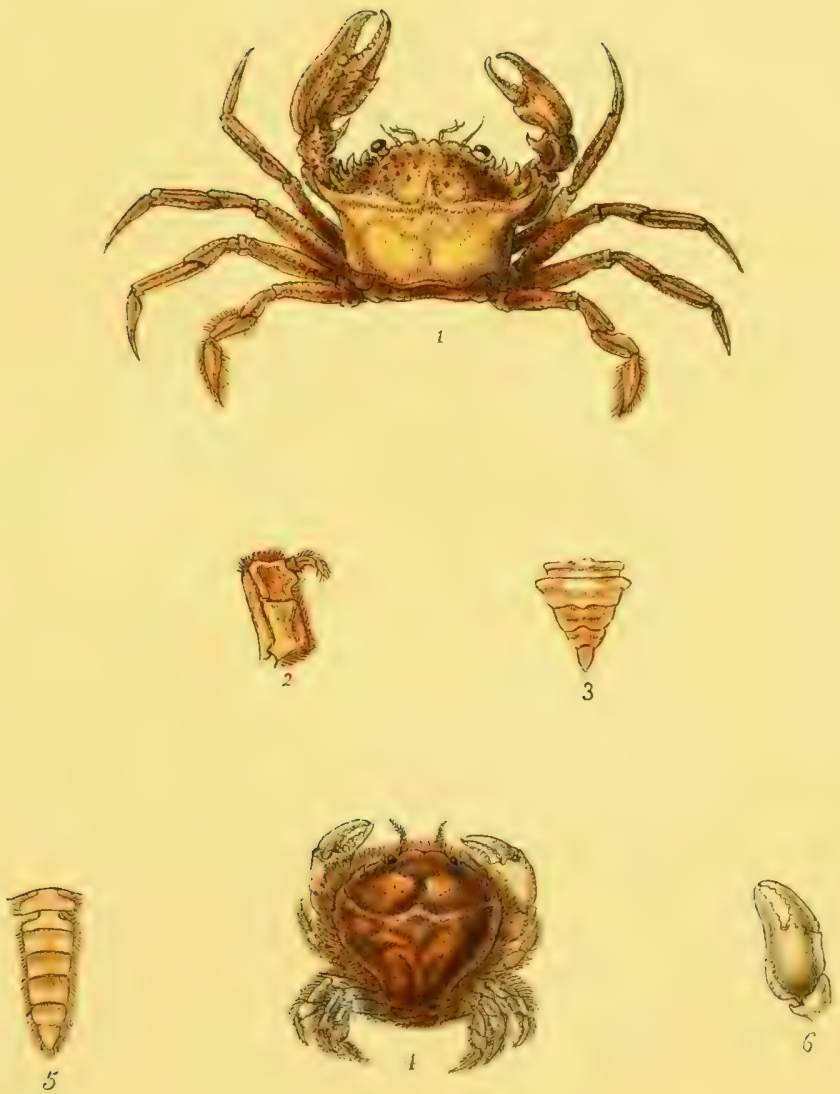


\section{.}




\section{POLYBIUS.}

Antenne cxlcrnce setacea articulis duobus primis majoribus, in oculorum cantho interno inserta.

P'edipalporum geminorum externorum caulis interni articulus secundus ad latus internum prope apicem emarginatus pro insertione palpi triarticulati, elongato-subconici.

Pcdum par anticum majus æquale didactylum, manibus externe elevato-lineatis : paria $2,3,4$, et 5 (pari 5 præsertim) compressa foleacea natatoria.

Abdomen aris 5 -articulatum segmeuto antepenultimo longiore basi utrinque abruptè producto: FEMIN 7 -articulatum; articulo ultimo præcedente abruptè angustiore.

Testc margo anticus arcuatus, semicircularis, lateribus 5-dentatis, sensim posticè in angulum convergentibus, apice subtruncato: diametro transverso submajore : orbita posticè externè bifissa, subtus externè unifissa, angulo interno imperfecto.

Oculi pedunculo suo brevi crassiores.

External antennæ setaceous, with the two first joints largest, inserted into the internal canthus of the eyes. External double pedipalpes, with the second joint of their internal footstalk notched near its apex, for the insertion of the palpi, which are three jointed and elongate-conic. Anterior pair of legs equal, didactyle, the hands externally with elevated lines; the other pairs, especially the last, compressed and formed for sivimming. Abdomen of the nale five-jointed ; the last joint but one longest; its base on each side abruptly produced. That of the female seven-jointed; the last joint abruptly narrower than the one before it. Anterior margin of the shell, semicircularly bent, its sides with five teeth, gradually converging into an angle behind, where it is truncated: its transverse, exceeding the longitudinal diameter : orbit behind externally with two fissures, beneath externally with one; its internal angle imperfect. Pecluncle of the eyes narrower than the eyes themselves.

The only species of this genus hitherto discovered, is described bclow.

\section{POLYBIUS HENSLOWII. \\ TAr. IX.-- B.}

P. testa planiuscula moderatim convexiuscula obscurissimè granulata utrinque 5-dentata : dentibus brevibus latis, fronte trilobo: lobo medio angustiore.

Fig. 1. Polybius Henslowii mas. 2. Femina. 3. maris abdomen. 4. femine abdomen.

This species was first communicated to me hy John Henslow, Esq. who found it in the net of a Herring fisher, on the Northern coast of Devon, in 1817. It was taken under similar circumstances in Pilchard-nets, off Bigloury Bay, in the South-Western coast of Devon during the same season by C. Prideaux, Esq. I have since received it from the Rev. Dr. Goodall, Provost of Eton, by whom it was observed in considerable plenty on the shore of Dorset opposite Portland Island, amongst the refuse from the nets of Fishermen.

Since writing the above, I have observed in the collection of the Linnean Society, a specimen of this species, which was taken off the coast of Spain, by the Rt. Honorable Sir Joseph Banks. 

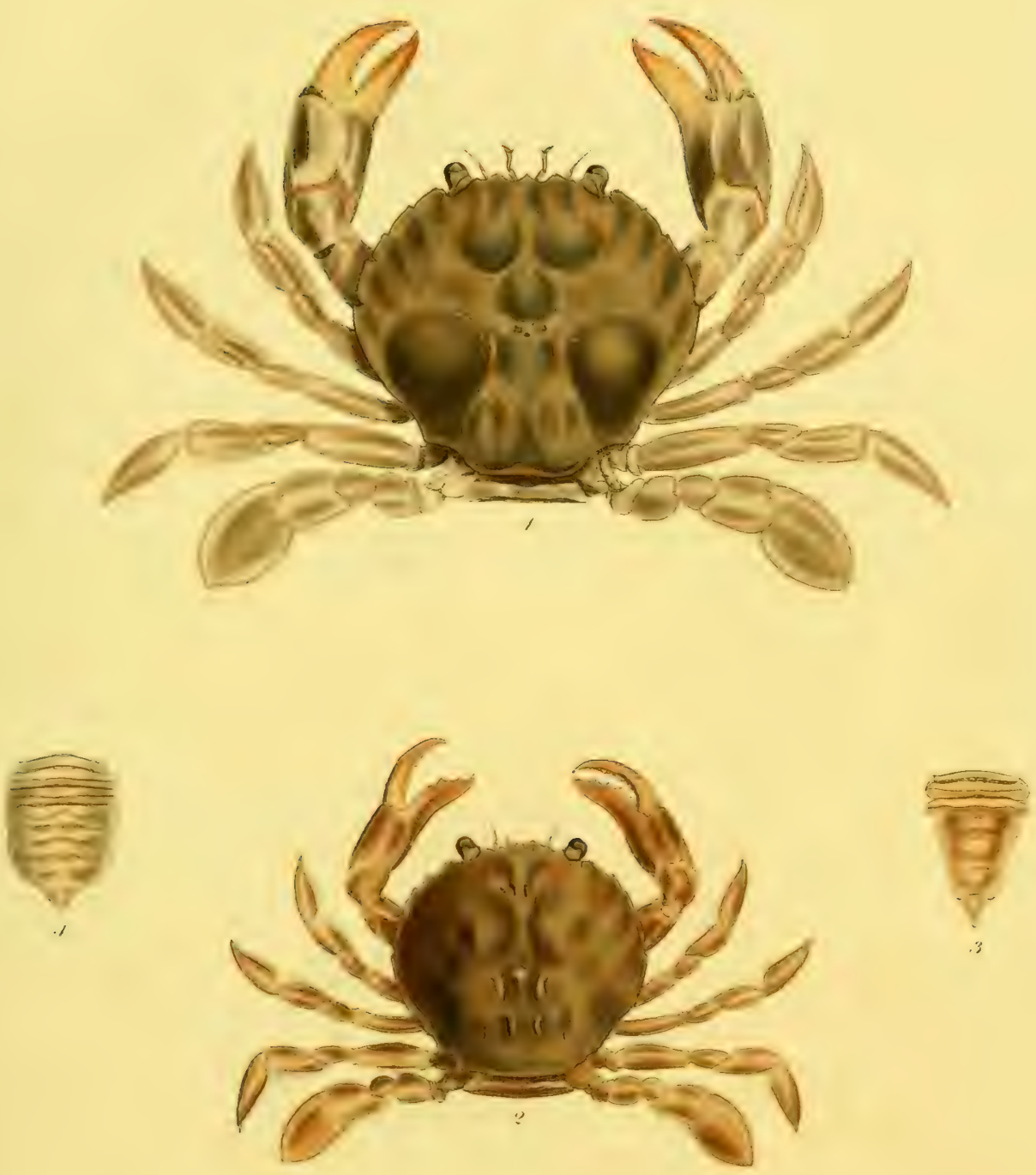



\section{CANCHR.}

\section{CANCER. Auctorum.}

Antenne externc breves, inter oculorum canthum internum et frontem inserta :

internce clypei medio, in foveolis receptac; pedunculus sublunaris.

Pcdipalpi gemini cxterni caulis interni articulo secundo ad apicem internum emarginato.

Pedum par anticum inequale didactylum: paria $2,3,4$ et 5 ambulatoria.

Abdomen Maris 5, FEMixa 7-articulatum.

Testa transversa, margine antico in lineam semiellipticam arcuato, portice marginata: orbitı

postice externe fissuris duabus, subtus fissuris duabus; una utrinque.

Oculi pedunculo brevi.

External antenne short, inserted between the internal Canthus of the eyc and the front. Internal antenna receired into foveola situated about the middle of the Clypeus ; their peduncles sublumate. External double pedipalpes, with the second joint of their internal footstalk notched at its internal apex. Anterior pair of legs unequal, didactyle: the other pairs formed for walking. Abdomen of the Male with five; of the Female with seven joints. Shell transverse; its anterior margin semielliptically bent, hinder part margined: Orbit with two fissures externally behind and with two below; one on each side. Eyes with a short peduncle.

\section{CANCER PAGURUS.}

\section{TAB. X.}

C. testa granulata utrinque novem-plicata, fronte trilobo.

Cancer Pagurus. Linn. Syst. Nat. XII. $i$. 104t.

- Fn. Sv. II. 2028.

Fabr. Ent. Syst. Supp. 334.

Latr. Hist. Nat. des C. et. des I. v. 365.

Herbst Krab. tab. 9. f. 59.

Penn. Britt. Zool. iv. 4. pl. 3.f. 7.

Leach Edin. Encycl. vii. 391. \& 430.

- Encycl. Britt. Suppl. i.

- Trans. Linn. Soc. xi. 320.

Cuv. Règne Animal, iii. 12.

Lam. H. N . des A. sans $\mathrm{Y}$. v. 270.

Fig. 1. Cancer Pagurus mas. 2. maris abdomen. 3. Femina abdomen. 4. Pedipalpus.

Cancer Pagurus, Crabe Pagure of French Naturalists, is the common Crab of our Markets, and is in season between Christmas and Easter, being by many esteemed more delicious than the Lobster, Astacus Gammarus. Its natural history is but little known. During the Summer months, it frequents all our rocky coasts, generally preferring deep water. It is more rarely met with in the Winter, when it is said to burrow in the sand. 
It is taken in wicker baskets resembling a common Mouse-trap, or in nets with large meshes, which are baited with garbage and sunk to the bottom of the sea. During the breeding season, the female approaches the shore and takes up her residence in a hole amongst the rocks, where she is very soon visited by the male, and if he be removed, another will be found at the recess of the next tide. Old Fishermen who are acquainted with this fact, discover as many females in their retreats, as possible, and are sure of two males a day from each female, for from three to five weeks.

The proportion of males to females, is, one to eleven, which is usual with most of the Brachyurous Malacostraca.

The tips of the claws, were formerly used in medicine, to correct acidities in the Stomach. 


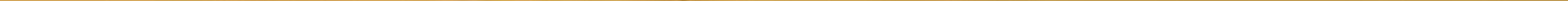





\section{XANTIIO.}

CANCER, Montagu.

XANTHO, Leach.

Antenne externce brevissimæ, in oculorum cantho interno insertæ :

internce sub clypei prominentis margine antico foveolis receptæ; pedunculo sublineari. Pcdipalpi gemini externi caulis interni articulo secundo ad apicem internum emarginato. Pedum par anticum inæquale didactylum : paria $2,3,4$ et 5 ambulatoria. Abdomen maris 5, Femine 7-articulatum.

Testa transversa, margine antico in lineam semiellipticam arcuato, posticè submarginata: orbita supra integra infernè externè fissurâ unicâ.

Oculi pedunculo brevi.

External antennæ very short, inserted in the internal canthus of the eye: internal antennæ received into foveola in the anterior prominent margin of the clypeus; the peduncle sublinear. External double pedipalpes with the second joint of the internal footstalk, notched at its internal apex. Anterior pair of legs unequal didactyle; other pairs formed for walking. Abdomen of the male five, of the female seven-jointed. Shell transverse; the anterior margin semi-elliptically bent, hinder part slightly margined; orbit entire above, externally beneath with one fissure. Eyes with a short peduncle. 


\section{XANTHO FLORIDA.}

\section{TAB, XI.}

X. carpis supra bituberculatis, testâ utrinque dentibus quatuor obtusis : interstitiis excisis, digitis nigris.

Cancer floridus. Montagu Trans. Linn. Soc. ix. 85. tab. 2. fig. 1.

Cancer incisus. Leach Edinb. Encycl. vii. 391.

Xantho incisa. vii. 430.

Xantho florida. Leach Trans. Linn. Soc. xi. 320.

$\operatorname{Var} \beta$. Digitis concoloribus.

Fig. 1. Xantho florida mas. 2. FeMina. 3. Maris abdomen. 4. Feminæ abdomen. 5. Antenna externa aucta. 6. Pedipalpus.

On the rocky parts of the southern coast of Devon this species occurs in very great abundance. The variety, with the tops of the claws of the same colour with the other parts of the animal, is not common. 

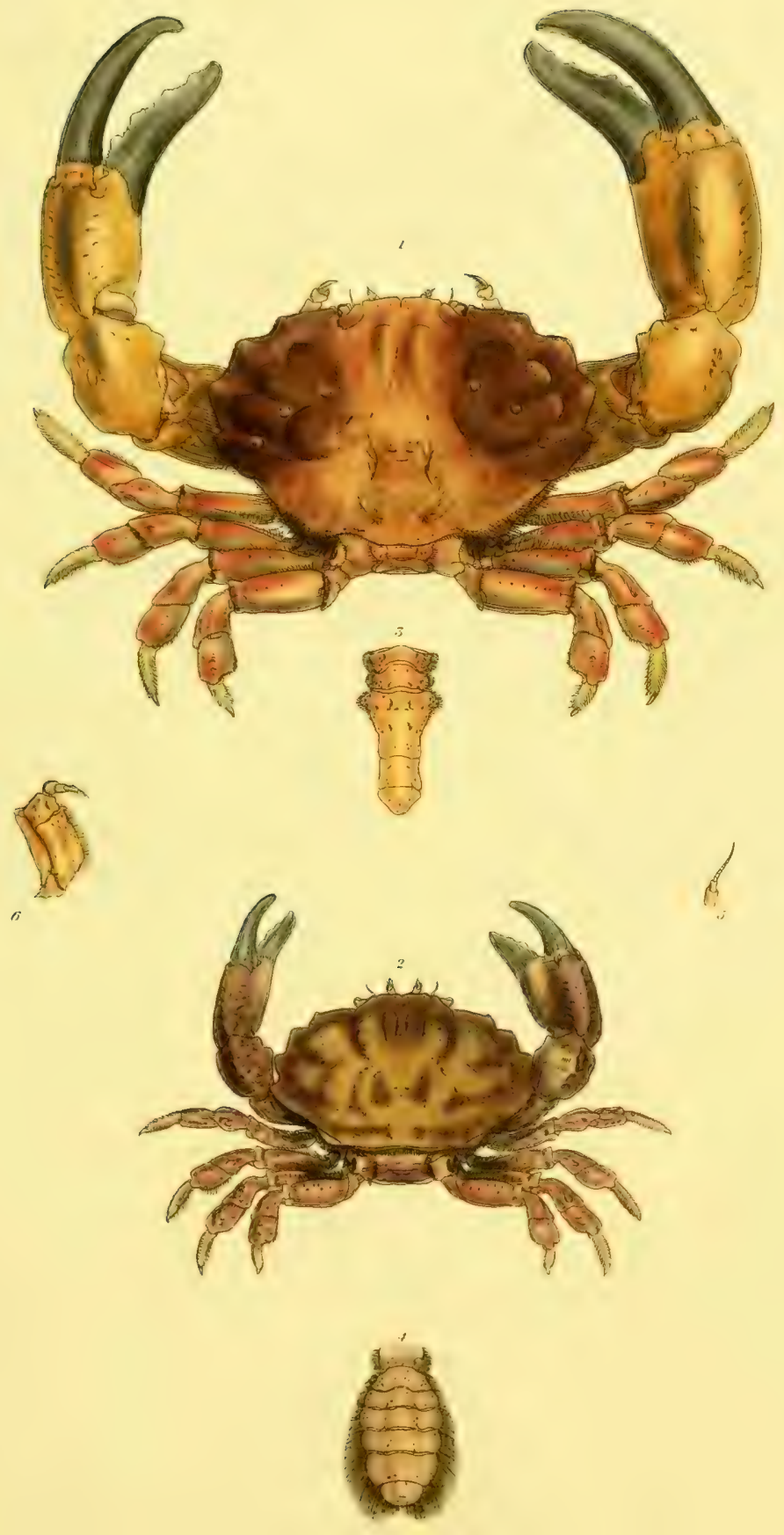



\section{PILUMNUS.}

\section{CANCER. Linné, Pennant.}

\section{PILUMNUS. Leach.}

Ancunce externe setacea, subelongata, graciles, ad oculorum canthum internum inserta :

interne in foveolis transverso-subobliquis reponendar.

Pedipalpi gemini cxterni caulis interioris articulo secundo sub transverso-quadrato, ad apicem internum emarginato, palpigero.

Pclum par anticum valdè inaquale, didactylum; digitis dentatis; paria alia ambulatoria; ungues apice acuti, nudi.

Abdomen in utroque sexu 7 -articulatum.

Testa transversa, postice truncata, margine antico in lineam scmiellipticam arcuato.

Oculi pedunculo brevi haud crassiores.

External antenna setaceous, subelongate, inserted at the internal angle of the eyes ; internal antenna placed in transverse somewhat oblique excavations. Extemal double pedipalpes with the second joint of their internal footstalk, having its internal apex notched for the insertion of the palpi. Anterior pair of legs very unequal, didactyle; the fingers toothed; other pairs formed for walking; claws with their extremitics sharp and naked. Abdomen in both sexes seven-jointed. Shell transverse, the anterior margin semielliptically bent, hinder margin truncate. Eyes not thicker than their peduncles, which are short.

The animals of this Genus live in holes of rocks and under stones in the sea. Their motion is slow, and all the species that I have seen are more or less covered with bristly hairs, which are most obvious on their legs. 


\section{PILUMNUS HIRTELLUS.}

\section{TAB。XII.}

P. testa utrinque 5 -dentata; dentibus duobus anterioribus minoribus, manibus, carpisque suprà et externè granulatis.

Cancer hirtellus. Linn. Syst. Nat. i. 1045.

Penn. Brit. Zool. iv. Pl. 6. fig. 11.

Leach Edinb. Encycl. vii. 391.

Pilumnus hirtellus. Leach Trans. Linn. Soc. xi. 321.

Var. $\beta$. maribus carpisque glabris non granulatis.

Fig. 1, Mas. 2, Maris abdomen. 3, Femina. 4, Feminæ abdomen. 5, Pedipalpus. 6, Antenna externa. 7, Antenna interna.

This species is extremely common all along the rocky shores that bound the South-Western coast of Devonshire, from Plymouth to the Berry Head, and may be taken under stones at low tide.

The fore legs vary; at one time the left, and at another time the right being the largest; besides which, the wrists and hands are sometimes quite smooth, without the slightest appearance of that granulated surfuce which Linnè considered as the essential mark of this species. 

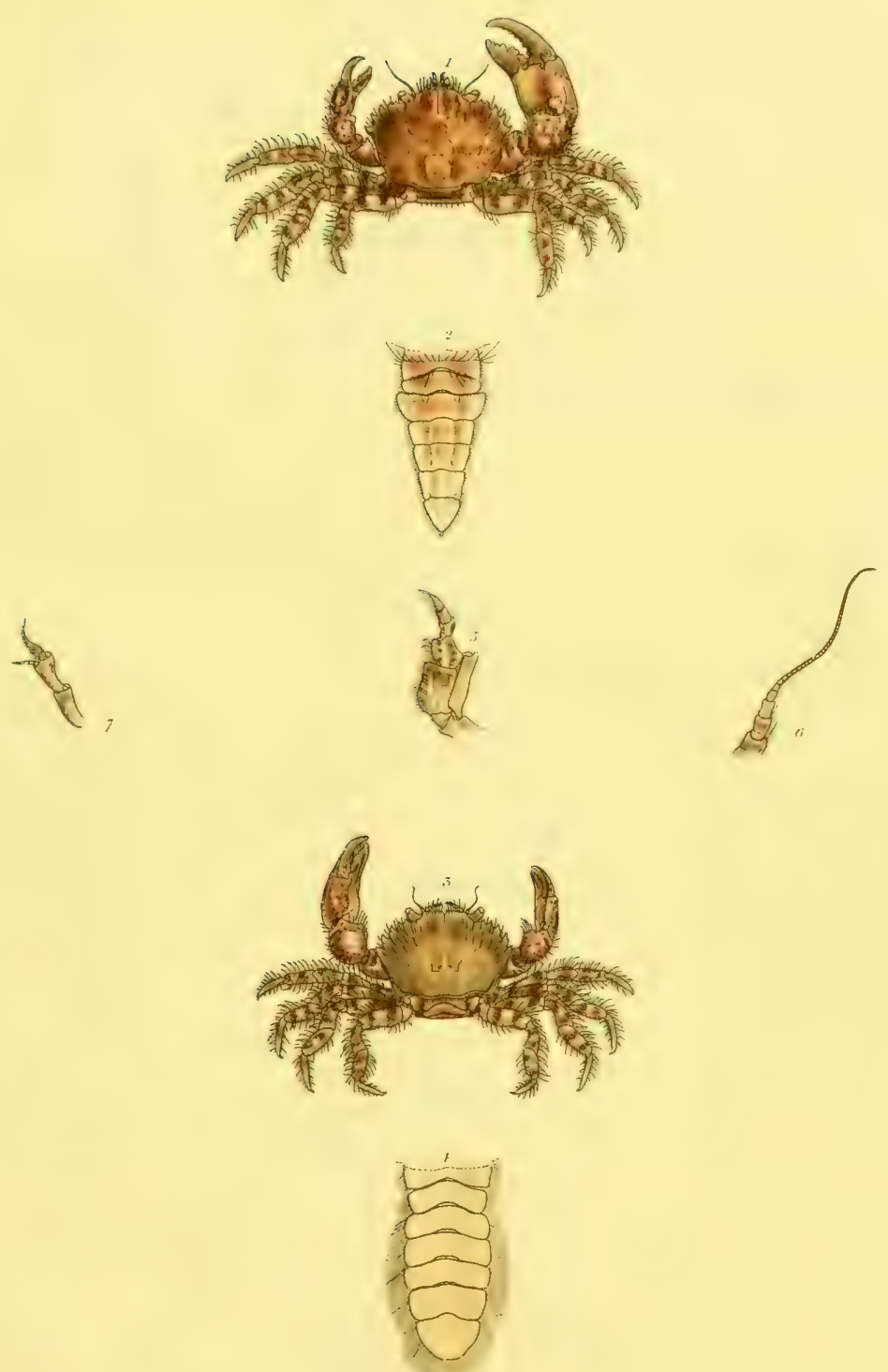



\section{GONOPLAX.}

OCYPODA. Bosc.

\section{CANCER. Pennant.}

\section{GONOPLAX. Leach.}

Antennce externce setacex, graciles, elongatæ sub oculis insertæ:

internce in foveolis transversis repositæ.

Pedipalpi gemini externi cauli interno biarticulato; articulo secundo quadrato ad apicem interiorem truncato-subemarginato, palpigero.

Pedum par anticum rquale, didactylum, Maris longissimum; FAMine testâ duplo longius; digitis subdeflexis internè inæqualiter dentatis; paria alia cursoria, ordine $4,3,5$ et 2 : ungues subcompressi, acuti.

Abdomen in utroque sexu 7 -articulatum.

Testa quadrata, transversa, anticè latior.

Oculi pedunculo articulo secundo valdc̀ elongato, ad testæ marginem anticum ferè attingente.

External antenne setaceous, slender and elongate, inserted under the eyes; internal antennæ situated in transverse excavations. External double pedipalpes with the second joint of their internal footstalk having its anterior apex truncate-subemarginate, for the insertion of the palpes. Anterior pair of legs didactyle; of the MaLe very long; of the Fenale twice the length of the shell; fingers internally unequally dentated; other legs formed for running, in order, according to their length, 4, 3, 5 and 2: claws sub-compressed, sharp. Abdomen (in both sexes) seven-jointed. Shell quadrate, transverse, broader before. Eyes with the second joint of their peduncles very much elongated, almost reaching to the anterior margin of the shell.

Of this Genus one species only is known, the economy of which will be given in the following page.

There is another Genus allied to Govoptax, and with it forms a stirps in one of the most interesting families of the brachyourous Malacostraca. 


\section{GONOPLAX BISPINOSA.}

\section{TAB, XIII.}

G. testa angulis anticis spini-formibus, lateribus utrinque, brachiis supra, carpis internè femeribusque apice unispinosis.

Cancer angulatus. Penn. Brit. Zool. iv. 7. Pl.5. fig. 10. mas.

Fabr. Suppl. Ent. Syst. 341.

Herbst. i. 85. Tab. 1. fig. 13.

Gmel. Syst. Nat. i. 2971.

Ocypoda angulata. Bosc. Hist. Nat. des crust. i. 198.

Ocypode angulata. Leach Edin. Encycl. vii. 393.

Gonoplax angulata. Leach Edinb. Encycl. vii. 430.

Trans. Linn. Soc. xi. 323.

Fig. 1, Mas. 2, Maris abdomen. 3, Femina. 4, Feminæ abdomen. 5, Mas junior. 6. Pedipalpus. 7, Antenna externa. 8, Antenna interna.

Gonoplax bispinosa was discovered at Weymouth by the late Dutchess of Portland, from whose cabinet it was first described and figured by Pennant. It is not uncommon in the Sound of Plymouth, and is often taken in trawl nets.

In the Kingsbridge estuary this species was first observed by Montagu, and has since been taken in great plenty by Mr. C. Prideaux, and by Mr. J. Cranch. The latter gentleman observes, that they live in excavations formed in the hardened mud, and that their habitations, at the extremities of which they live, are open at each end. The large specimens from which the annexed figures are taken, occurred at a bank called the Dentridge, which is rarely uncovered excepting at very low tides.

The colour is yellowish red, the thumb only being blackish or greenish-black.

The anterior legs of the adult male are nearly five times the length of the shell, but in younger specimens they are but little longer than those of the females, in whom they are about twice the length of the shell. 

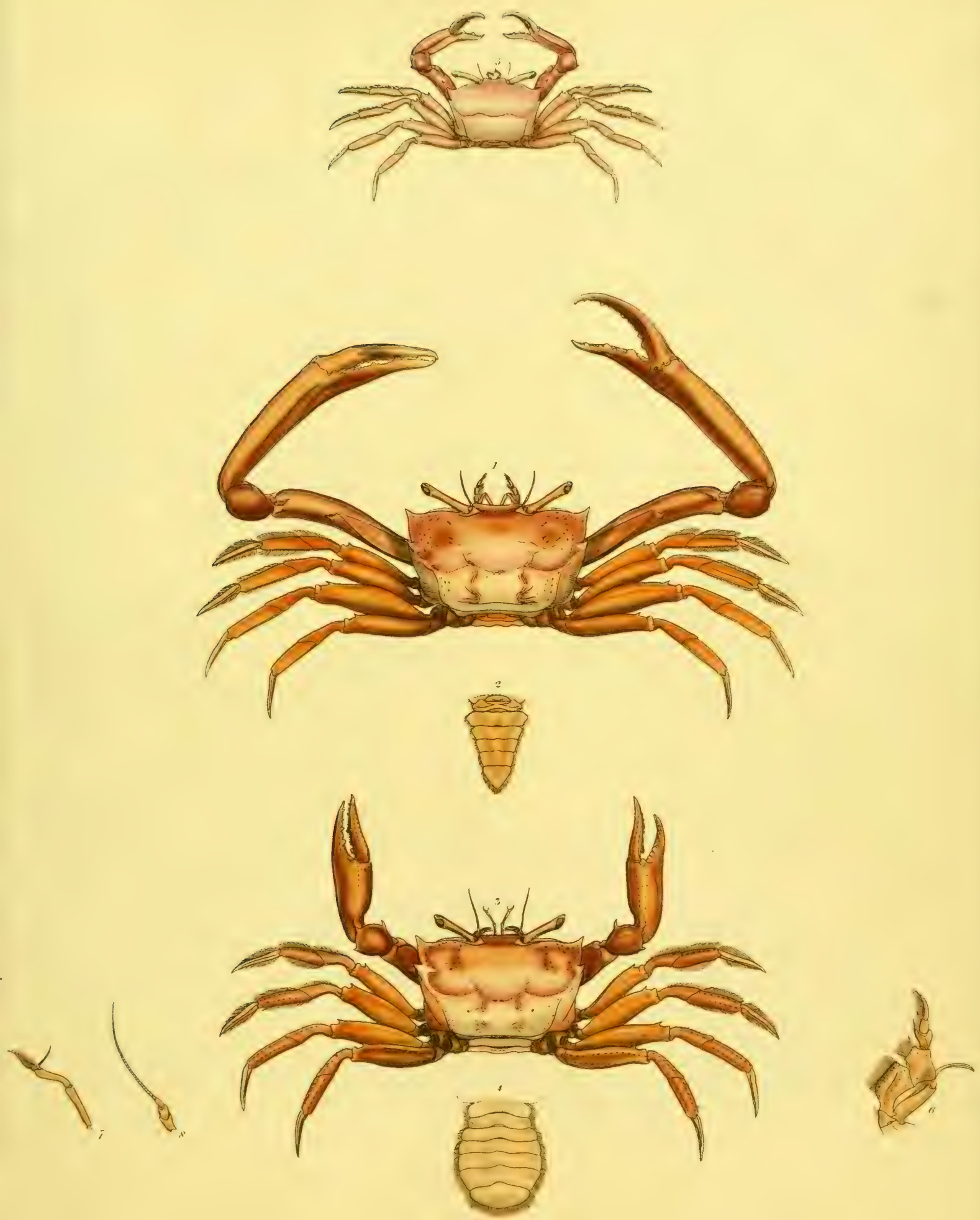



\section{PINNOTHERES.}

\section{PINNOTHERES. Latrcille, Bosc.}

CANCER. Linn., Gmel., Penn.

\section{ALPHAUS. Daldorff:}

Antennci axterna sctacea, brevissima, (articulis tribus prinis majoribus,) in oculorum cantho interno insertac.

7.dipalyorum giminorum cxtomorun caulis internus uni-articulatus ad apicem subabrupto acuminato-rotundatus, palpigerus.

Jidum par anticum aquale; paria $2,3,4$, et 5 simplicia, (naris prasertim) compressa, pari quinto breviore: Ungues arcuati, acuti, validi.

Abdomen in utroque sexu $\%$-articulatum.

Tist orato-orbiculata, orbiculato-subquadrata aut transverse subquadrata.

Oculi crassi pedunculo brevi, in fronte inserti inter se dissiti.

External anteme setaceous, very chort, inserted at the internal coner of the eye, the thrce first joints largest. Intemal footstalk of cxternal double palpes one-jointed, with the apex sonewhat abruptly acuminate, rounded and bearing the palpes. Anterior pair of legs equal, didactyle; the other legs simple compressed (especially in the male), fifth pair shortest: nails bent, sharp and strong. Abdonen seven-jointed in both sexes. Shell avote-orbicular, orbicularquadrate or transverscly-subquadrate. Eves thick, with shont footsialks, inseried at a distance from cacli other in the front of the shell.

All the Pinnotheres inhabit bivalve shells, and were suppesed by snu: of the ancients to be consentaneous inmates with the animal, bound by mutul interest; the fable is bcautifully told by Oppian, and is alluded to by Cicero*

Aristotle supposcl them to act as centinels, and believer? that the guaded the Pinna (the shell in which they were first obecrved) from the atiachs of its encmies; Rondeletius and some other naturalists held the same opinion.

The species are but little understood, and it is cren probable that I niay in some instances have considered the sexes as distinct species; those which are decribed, howerer, lave reecived the sanction of my friend MIr. Montagu, who entertidis the same opinions vith lat? relf on this dificult subject, and to whom my warnest thanks are due for the trotible and tine which he has ever most hiudly and willingly bestowed in giving me his opinion when it has becis requircel.

3. "Pinna vrò, ( cic exim gracè dicitur,) duabus grandiłus patula conchì, cum parva squilla quasi socic latem coit

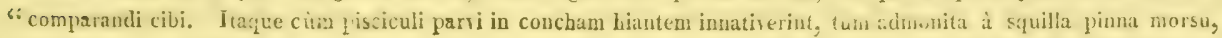
"comprimit conchas."

Cic, de nat. Deor. Iib. 2. Sec. XLVIII. 


\section{PINNOTHERES PISUM.}

\section{Tab. XIV. FIG. 1, 2, and 3.}

3. (FCn.) Tésła orbiculało-subquadrata, molliuscula, glaberrima, fronte subarcuato, integro; manibus oblongis subtus femoribusque supra linea ciliata; pollice subarcuato; ablomine Jatissimo segmenformm lateribus arcuatis, articulo quinto latiore, ultimo præcedente angurstiore, apicc tenuè et obscurè at latè emarginato.

Cancer Pisun. Timn. Syjst. Nat. cal. XII. 1039? Pcnn. Brit. Zool. II: 1. T. 1.f. 1. Fabr. Suppl. Ent. Syst. $3 \$ 3$.

Pimnotheres Pisnn, Latr. Gon. Crust. ct Iils. T. 1. p. 33. Bosc Hist. Nat. dis Crust. 1. 213. Habitat inter Modiolorum, Mytilorum testas frequentissime.

Fig. 1, mag. nat. 2, cad. sp. aucia. 3, Femine abdomen auctum. * Pedipalpus geninus externus auctus.

It is not without doubt that I have quoted this species (which is very often found in the shells of Modioli and Mytili) as Cancer Pisum of Limasus, as he las described it to be of the size of a pea, ("magnitudine pisi"), without making any mention of its habitat.

The shell of the female is orbiculate-quadrate, soft, very smooth, with the front slightly arcuate and entire; hands oblong, with a ciliated line beneath; thighs with a ciliated line above; thumb slightly bent; abdomen very broad, with the sides of the segments arcuate, the fifth segment broader, the last narrower than the sixth, obscurely but broadly emarginate. Male unknown.

\section{PINNOTIERES CRANCHII.}

\section{Fig. 4 and 5 .}

P. (Fem.) Testa orbiculato-subquadrata, molliuscula, glaberrima, lateribus postice dilatatis; fronte recto, obscure subcmarginato; manibus oblongis subtus fenoribusque supra linea ciliata; pollice subarcuato; abdomine latissimo segmentis lateraliter subarcuatis secundo sequentibusque postice distincte emarginatis, segmento quinto sublatiore; ultino præcedente angustiore.

I Iabitat in Modiolis, Mytilis rarius.

Fig. 4, Fem. mag. nat. 5, Feminæ abdomen mag. nat.

This new species was discovered by Mr. J. Cranch (a most assiduous Collector of marme productions) in the Kingsbridge estuary, where it is cccasionally found in Modioli and Mytili. It is casily distinguished from P. PIsum by the form of the frout, which is straight and slightly emarginate, by the breadth of the hinder part of the sides of the shell, and by the abdomen, all the joints of which, excepting the first, are distinctly notched bchind. Nale unknown. 

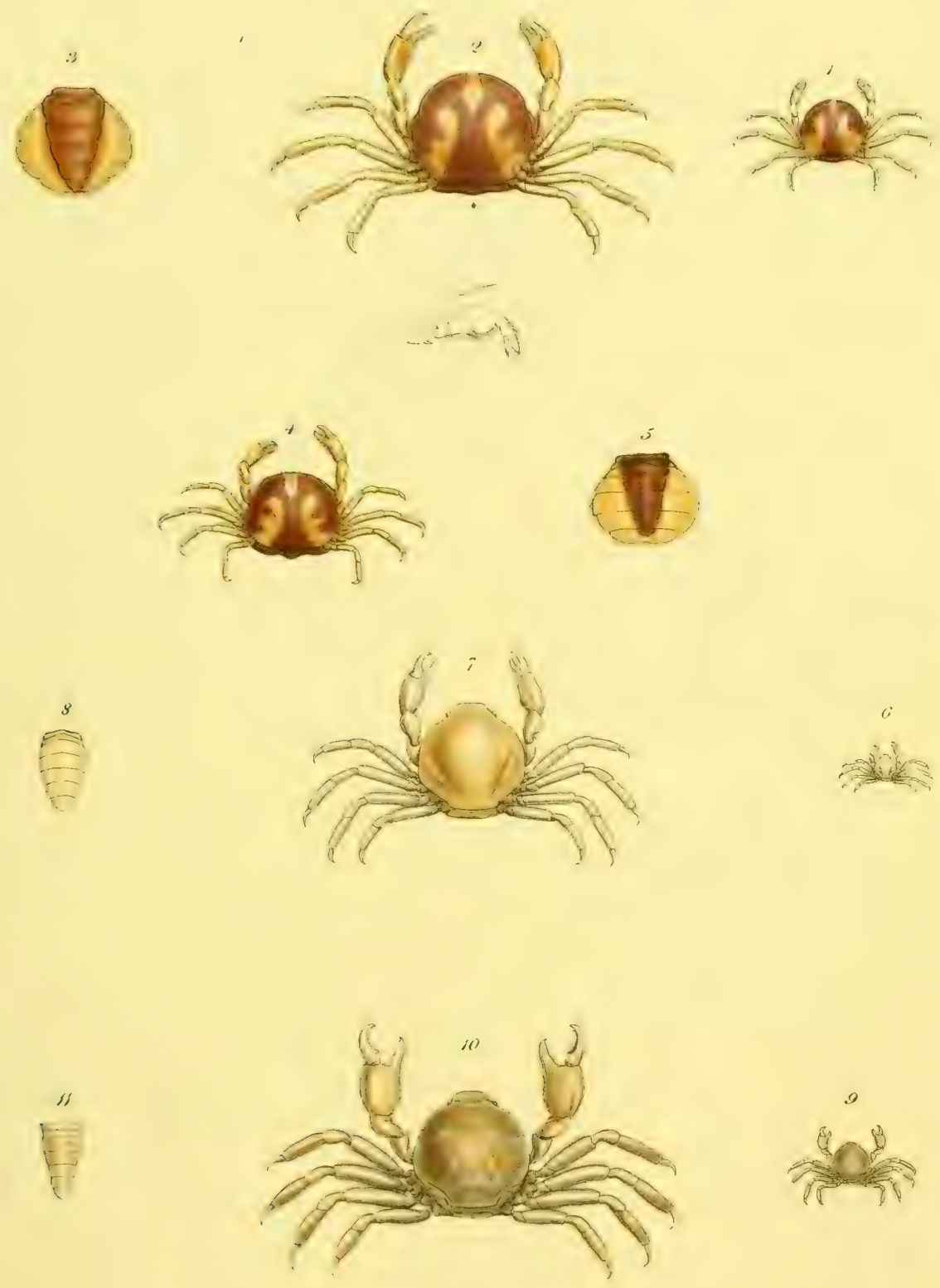



\title{
PNNOTHERES EATIREIEII.
}

\author{
Fig. $6, \gamma$, and 8 .
}

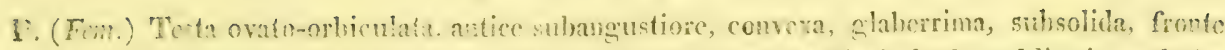

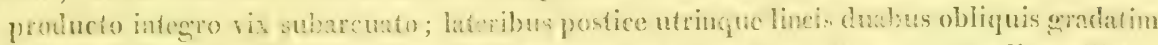

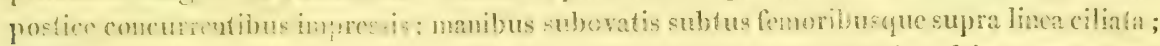

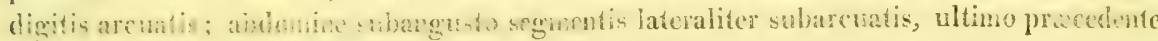
angustiore, apice stubacuminato, rotundato, integro.

Cancer nytillorun albus. Merbst. 1. 101. T. 2. fig. 24?

Pinnotheres mytillorum. Latr. Gcn. Crust. et Ins, 1. 35. Lcach.

Leach Edin. Enc. a)t. Crust.p. 430.

Habitat in Modiolis rarissime.

Fig. 6, mag. nat. 7 , ead. auct. 8, feminæ abdomen auctum.

A single snecimen of this elegant intle crall was taken by myself in the Frith of Forth. Although a female, it has wey much the genoral appenance of the male of the following speries,

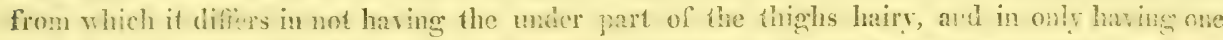
line of cilin under the hanis; lint the most remarkale point of cistinction is in the two inpressed lines on each side of the hinder part of the shell.

The abromen in the more adult state is probably as broad as in the precesing species. Montagu supposes it to be the young of $P$. Pisum. Male unknown.

\section{PINNOTHERES VARIANS. \\ FIG. 9, 10, and 11.}

P. (1Tus) Testa ovato-orbiculata, mice subangustiore, convexa, glaberima, soliha; fronto prolucto, arcuato, integro; manibus oratis subtus lineis duabus ciliatis; digitis ralde arcuatis; femoribus supra ac infra linea ciliata; abdomine lateribus lace enarginatis, articulo ultino precedente abrupte angustiore, apice angusto, rotundato, integro.

Cancer varians. Oliv. Encycl. méth. hist. nat. tom. 6. p. 155.

Cancer minutus. Penn. Bril. Zool.?

Cancer mytillorum fuscus. Herbst Tab. 2. fig. 25.

Habitat in Modiolis et Mytillis sat frequens.

Fig. 9, mas magn. nat. 10, idem amplificatus. 11, maris abdomen auctum.

This spesies, which I formerly considered as the male of $P$. Pisum, is found with that species in Modioli and Mytilli.

Latroille considers this as the sane species with $P$. Latrillii, and Pennant seems to have given it, or some species alin to it, as the Linnean Cancer minutus, which is a species of the genus Gransus.

The contour and conistance of the shell in this and in the proceding species is licarly the same, but they are readily distitiguished by the characters pointed out above, Th. female (unless she be $P$. Pisum) is unluown. 



\title{
PINNOTHERES VETERUM.
}

Tab. XV. Fig. $1,2,3,4$, et 5 .

P. Fronte subemarginata; manibus infra arcuato sinuatis.

(1/as.) Testa transverso-subquadrata, subsolida, punctata ; manibus ovatis digitis arcuatis : abdomine lateribus integris segmento vitimo pracedente abrupte latiore apice acuminatorotundato.

( $1 \mathrm{~cm}$.) 'Testa subtransverso-subquadrata, molliuscula, punctulatissima; manibus elongatoofatis digitis subarcuatis; abdomine latissimo noduloso-carinato, segmentis 5,6 , et 7 postice emarginatis ultimo præcedente angustiore.

Cancer pinnotheres, Linn. Syst. Nat. XII. 1. 1040. 9.

Oliv. Encycl. Method. Crabe. 23.

Pinnotheres veterum. Bosc Hist. Nat. des Crustacés. 1. 243.

Pinnotheres pinnæ. Leach Edin. Encycl. 7. 431.

Fig. 1, Fem, mag. nat. 2, ejusdem abdomen. 3, Mas. mag. nat. 4, sex idem amplificatus.

5, maris abdomen amplif.

Habitat intra Pinnas, Ostreas rarius.

Mus. Montagu, Mas, et Fem. Francillon, Leach, Prideaux, Fem.

Montagu first observed this interesting species in Britain; he found both sexes in Pinnæ from the Salcombe estuary, where it has likewise been taken by Mr. J. Cranch.

It occurs envelloped in the mantle of the Pinna, but it is not confined to that genus of animals, having been once noticed in Ostrea edulis (the common oyster) by my assiduous friend Mr. C. Prideaux. 'This is most probably the species alluded to by Cicero and Pliny*, and may be the same with the species given in vol. 2. tab. 3t, of the splendid work of Poli on the shells of the Sicilies; but the figure is not sufficiently correct to enable me to refer to it with any degree of certainty.

\section{PINNOTHERES MONTAGUI.}

\author{
Fig. 6,7 , et 8 .
}

P. (Mas.) Testa transverso-subquadrata, subsolida, punctata, fronte emarginata; manibus ovatis; digitis arcuatis; abdomine lateribus late emarginatis, segmento ultimo præcedente subabrupte latiore apice obtuse rotundato, integro.

* Hist. Nat. Lib. 9. cap; 42. 
Pinnotheres modioli. Leach Edin. Encycl. 7. 431.

Habitat in Modiolorum testis; semel obvius.

Mus. Montagu.

Fig. 6, mas. 7, mas amplificatus. 8, ejusdem abdomen auctum.

This species was discorered in a Modiolus from the Salcombe estuary by Montagu, who sent it to me as Cancer minutus, which is, as I before remarked, referable to the genus Grapsus.

This and the preceding species differ from those figured in Tab. 14, by having their whole shell more or less punctate, and may on further examination be found to constitute a division of the genus.

$P$. Montagui is distinguished from $P$. Veterum by the form of its abdomen, by the greater depth of the notch in the front of the shell, and by the form of the fore feet; the last character for discrimination is obscure, and may be more easily seen than described. 
Yell: IT.
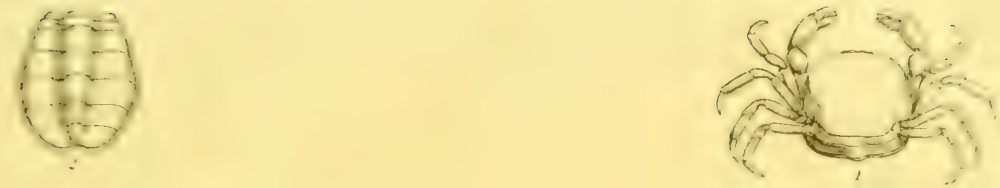

(4)
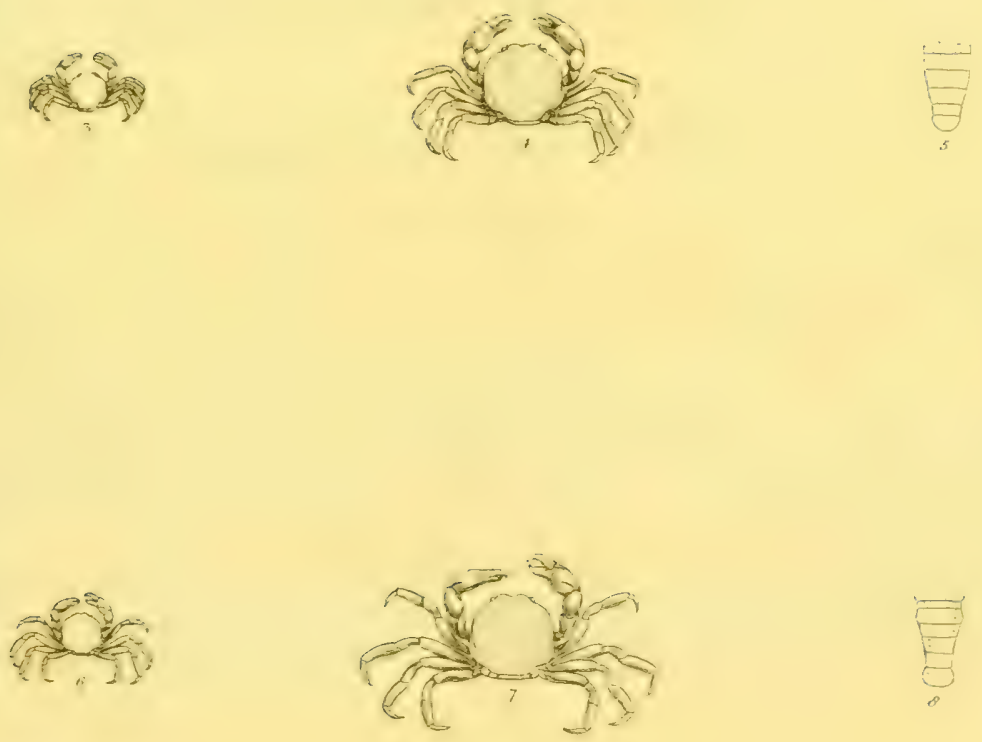
. 


\section{MEGALOPA.}

\section{MEGALOPA. Leach.}

Antenne cxternce setacex articulis elongatis :

internce setis duabus articulatis terminatx; superiore longiore.

Pedipalpi cxterni caule interno articulis duobus primis compressis; secundo breviore apice exteriore producto palpigero.

Pedes decem ; par anticum majus didactylum; paria alia consimilia ungue simplici instructa. Abclomen 7 -articulatum.

Testa elongata anticè rostro lato instructa.

Oculi maximi ; peduncula oculis non angustiora, articulo secundo cylindrico.

External antenna setaceous, with elongated joints: the internal ones terminated by two articulated seta, the upper of which is the longest. External pedipalpes with the two first joints of their internal footstalks compressed ; the second shortest with its internal point produced and palpigerous. Legs ten ; the anterior pair largest and didactyle; other pairs alike, terminated by a simple claw. Abdomen seven jointed. Shell elongate, the front furnished with a broad flat rostrum. Eyes very large, their peduncles not narrower than the eyes, with their second joint cylindric.

\section{MEGALOPA MONTAGUI.}

\section{Tав, XVI.---Fig. 1---6.}

M. rostro integro apice uni-spinoso, testâ posticè inermi, coxis octo anticis spinâ curvatâ instructis.

Cancer rhomboidalis. Mont. Trans. Linn. Soc. vii. 84. tab. vi. fig. 1.

Megalopa rhomboidalis. Leach Edinb. Encycl, vii. 431.

Fig. 1. Megalopa Montagui mag. natur. 2. Eadem aucta. 3. Antenna exterua amplificata. 4. Antenna interna auct. 5. Pes anticus sinister auctus. 6. Pes secundi paris ampl.

Montagu discovered one specimen of this species amongst corallines on the back of Maïa Squinado, on the southern coast of Devon; and I have received from J. Bulwar, Esq. two others that were taken amongst some floating marine plants in Torbay. 


\title{
MEGALOPA ARMATA.
}

\author{
Fig. 7---9.
}

M. rostro integro apice uni-spinoso, testâ posticè carinatâ ; carinâ in spinam acutam prodeunte, coxis quatuor anticis spinâ curvatâ instructis.

Fig. 7. Megalopa armata mag. nat. 8. Eadem amplificata. 9. Pedipalpus externus auctus.

The discovery of this new species is due to the indefatigable zeal of C. Prideaux, Esq. who took two specimens from a crab-pot in Bigbury Bay, South Devon. 

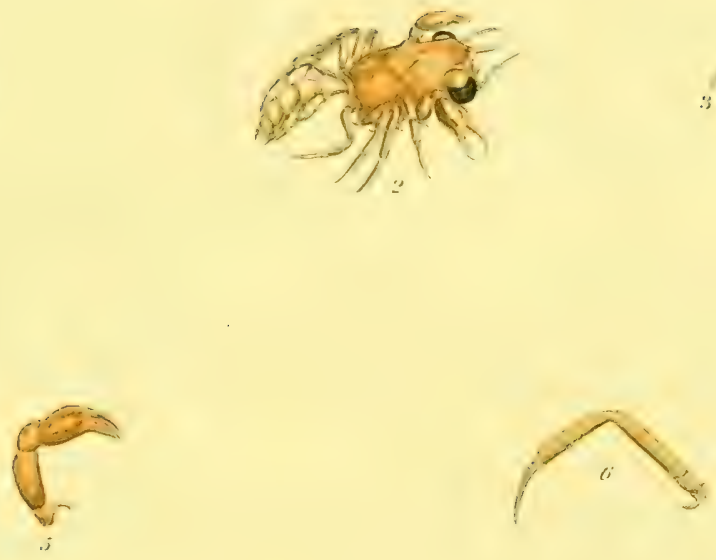

6

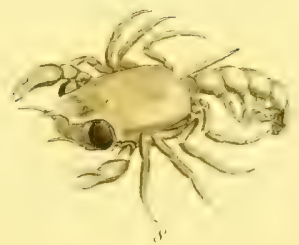




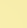




\section{EURYNOME.}

\section{CANCER. Pennant.}

\section{EURYNOME. Leach.}

- Intchne cxicrna distantes rostro panlulum longiores, in oculorum cantho interno inserta, articulis primo secundo subbreviore, tertio minore, ultimo e plurimis segmentis efformato piloso.

Pidipalpi gemini extermi caulis interni articulo sccundo ad apicem interiorem truncato-emarginato. Pcdum par anticum aliis crassius didactylum digitis deflexis; MARIs corpore triplo longius,

FEnIse corpore longius; paria $2,3,4$, et 5 , consinilia, mediocria; ungues acuti apice nudi. Tista subtriangularis verrucata antice rostrata; rostrum bifidum laciniis divaricatis: orbita superne fissura unica, infra externe emarginata.

Oculi distantes globosi pedunculo mediocri crassiores.

Abdomen 7-articulatum;

Maris articulis tertio latiore, ultime acuminato apice rotundato;

FEMIN ovatum late ciliatum.

External antennæ distant, a little longer than the rostrum, inserted at the internal corner of the eye, the first joint rather shorter than the second, the third less, the last hairy and composed of several segments. External double feet-palpes with the interior point of the second joint of their internal footstalks truncate-emarginate. Anterior pair of legs thicker than the others, didactyle with deflexed fingers, of the Male three times the length of the body, of the Female longer than the body; second, third, fourth, and fifth pair of moderate length. Claws sharp, with naked tips. Shell somewhat triangular, warted, terminated anteriorly by a bifid rostrum with divaricating lacinix; orbit above with one fissure, beneath externally with a notch. Eyes distant, thicker than their peduncle, which is of moderate length. Abdomen seren-jointed; of the Male with the third joint broader than the others, the last joint acuminate with a rounded joint; of the Female ovate and broadly ciliated. 


\section{EURYNOME ASPERA.}

\section{TAB. XVII.}

E. pedibus anticis femoribusque tuberculatis; dorso tuberculis octo elevatioribus $2,1,2,3$ plurimisque aliis irregularibus depressis pilis-marginatis; lateribus utrinque lamellis quatuor; rostro laciniis simplicibus, acuminatis.

Cancer asper. Pen. Brit. Zool. IV. 18. Pl. IX. A. 20.

Eurynome aspera. Leach Edin. Encycl. 7. 431.

Fig. 1, Mas. 2, Maris abdomen. 3, Femina. 4, Femina abdomen. 5, Pedipalpus externus geminus áuctus.

This species, which is the type of the genus, and the only one that has hitherto been noticed, is found by dredging in deep water on the coasts of Dorset, Devon, and Cornwall. The very fine specimens figured in the plate, were sent to me by my very industrious friend, C. Prideaux, Esq. who obtained them from the trawl-fishers of the Plymouth Sound.

Many of the tubercles on the back of the shell have a cauliflower sculpture. 

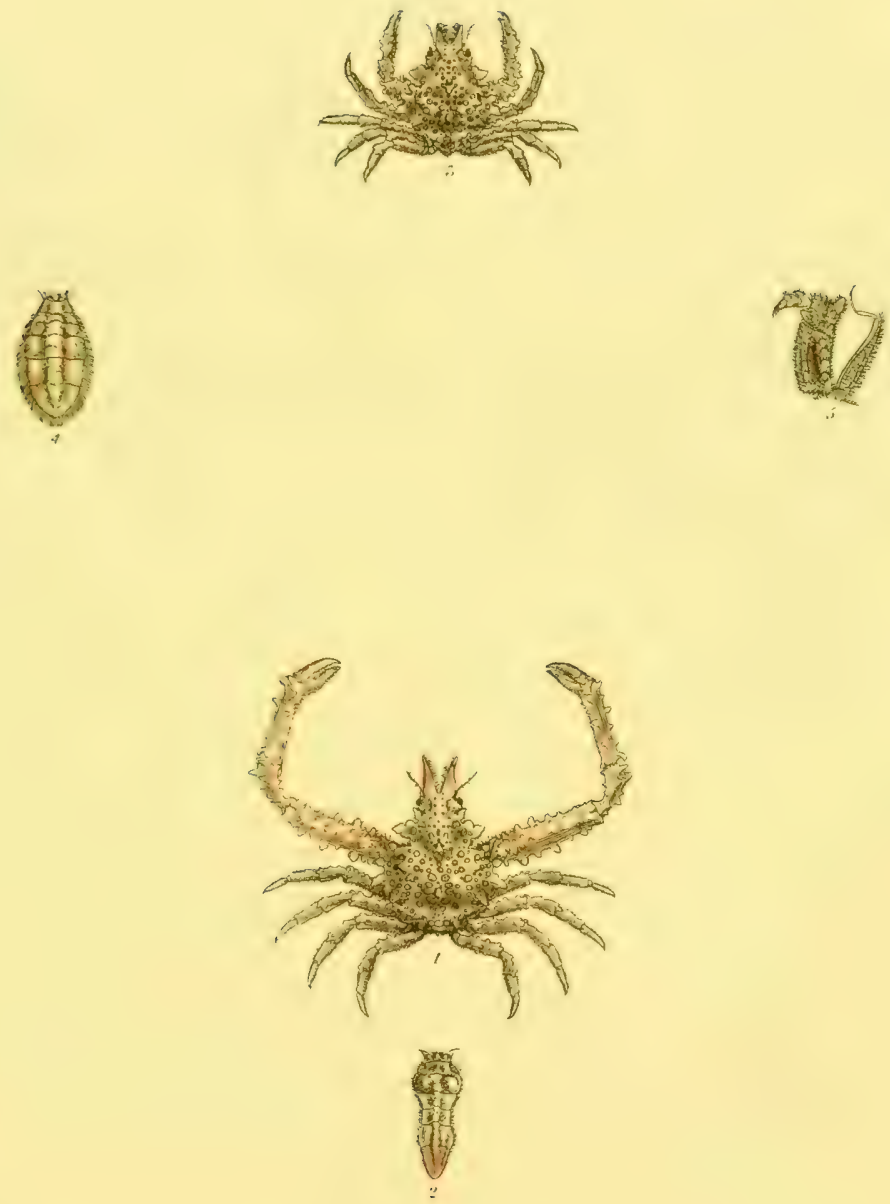



\section{MAIA:}

$\operatorname{MAT}^{\sim} \mathrm{A}$, Aristotelis.

MIAIA, Lamarck, Latreille, Bosc, Leach.

CANCER, Olivier, Scopoli, Herbst. Sowerby.

Anteme cxteme setaceas, articulis duobus basilaribus crassioribus et longitudine subxqualibus; articulo primo subcrassiore.

Pedipalpi extermi caulis interni articulo secundo ad apicem internum profundè cmarginato.

Pedum par anticum aliis haud aut vix crassiores : paria octo postica subelongata consimilia, unguibus simplicibus apice nudis, acutis.

Abrlomen 7-articulatum.

Tesłl connexa oxato-subtriangularis, spinosissima, anticè rostro bifurco terminata.

Oculi pedunculo suo elongato haud crassiores.

External antemne setaceous with the two first joints thickest and nearly equal in length; the first joint thickest. External pedipalpes with the second joint of their internal footstalk deeply notehed at its internal apex. Anterior pair of legs not or scarcely thicker than the rest : the other legs alike in form, subelongate: the claws simple, with their joints sharp and naked. Abdomen seven-jointed. Shell convex, orate-subtriangular, very spinose, terminated anteriorly ly a bifurcate rostrum. Eyes not thicker than their peduncles which are elongate. 


\section{MAIA SQUINADO. \\ TAв, XVIII.}

M. testâ fasciculato-pilosâ, orbitâ supernè spinâ unicâ, lateribus validé 5 -spinosí, clypeo infra frontem spinâ breviusculâ supra excavatâ.

Cancer Squinado. Herbst. iii. tab. 56. adultus.

$$
\text { i. } t .14, f, 84,85 \text {. }
$$

Cancer Maïa. Scopol. Ent. Carn. 1126

Sowerby Brit. Miscel. t. 39.

Cancer spinosus. Oliv. Encycl. méth. hist. nat, vi. 173.

Maja Squinado. Latr. Gen. Crust. et Ins, i. 37.

Bosc, Hist. Nat. des. Crust. i. 257.

Leach, Edinb. Encycl, vii. 394.431.

- Trans, Linn. Soc. xi. 326.

Encycl. Britan. Suppl. i. $\mathbf{4 1 5 .}$

Fig. 1. Mä̈a Squinado mas. 2. Antenna cxterna. 3. Pedipalpus externus. 4. maris abdomen. 5. Fемins jun, abdomen. 6. Maïa Squinado fonnes, jun.

This animal has been confounded with Lilhudes Mä̈a and with Parthcnope horrida in many cabinets. It is extremely common in deep water off the South Western coasis of Deron and Cornwall, being called by the fishermen King-crab or Thornback.

In the young state it approaches the shore, and is often taken in the common net: it differs so much in general appearance from the adult, that a figure of it is added. 



\section{PISA.}

\section{CANCER. Peniant, Herbst, Monlagu.}

INACHUS. Fabricii.

\section{MAJA. Lalreille, Bosc.}

PISA. Leach.

\section{BLASTUS. Leach.}

Anfence cx!crne setacex, hirta, pilis basilaribus clavatis, articulo primo secundo multo longiore. Pidipalpi gemini cxterni caulis interni articulo secundo ad apicem internum emarginato aut truncato.

Pcdum par anticum majus crassius (Maris corpore lengius, Fenune corporis longitudine); paria octo postica mediocres, unguibus denticulatis apice nudis. Aldomen 7-articulatum.

Tista subtriangularis, villosa, tuberosa, anticé rostro laciniis divaricatis terminata. Oculi pedunculo vix crassiores.

\section{GENERIS DIVISIONES.}

* Testa densius villosa, latcribus utrinque posticé spina terminatis. (PISA. Leach.)

** Testa villosa lateribus spinosis. (BLastus. Leach.)

External antennæ setaceous, hairy, the lowest hairs clubbed, the first much larger than the second joint. External double footpalpes with the second joint of their internal footstalk notched or truncate. Anterior pair of legs didactyle and thicker than the rest; of the male larger than the body; of the female the length of the body: other legs moderate in length, arired with claws having naked tips and their internal edge denticulated. Adomon 7-jointed. Shcll somewhat triangular villose, tuberose, terminated in front by a bifid rostrum with divaricating points. Eyes scarcely thicker than their footstalks.

\section{DIVISIONS OF THE GENUS.}

* Shell more thickly villose, the sides behind terminated by a spinc.

** Shell villose, with spiny sides.

Of the economy and mode of life of this genus nothing is known. 


\section{PISA GIBBSII.}

\section{Tab. XIX.}

P. rostro deseendente; testa spina utrinque pone oculos; brachiis femoribusque inermibus. Cancer biaculeatus. Montagu Trans. Lim. Soc. XI. 2, t. 1.f. 2.

Pisa biaculeata. Leach Edinb. Encycl. VII. 431.

Pisa Gibbsii. Leach Trans, Linn. Soc. XI. 327.

Fig. 1, mas. 2, pedipalpus gem. extern. 3, maris abdomen. 4, feminx abdomen.

Pisa Gibbsii is not an uncommon species on the Southern coasts of Devon and Cornwall; it inhabits deep water, and is taken by the Trawl net.

It was first noticed by Mr. Gibbs, employed by Montagu, and is named after that indefatigable and successful collector, by whom the British Fauna has been considerably enriched.

The shell, when the hair is removed, is whitish and covered with impressed punctures. 


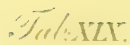
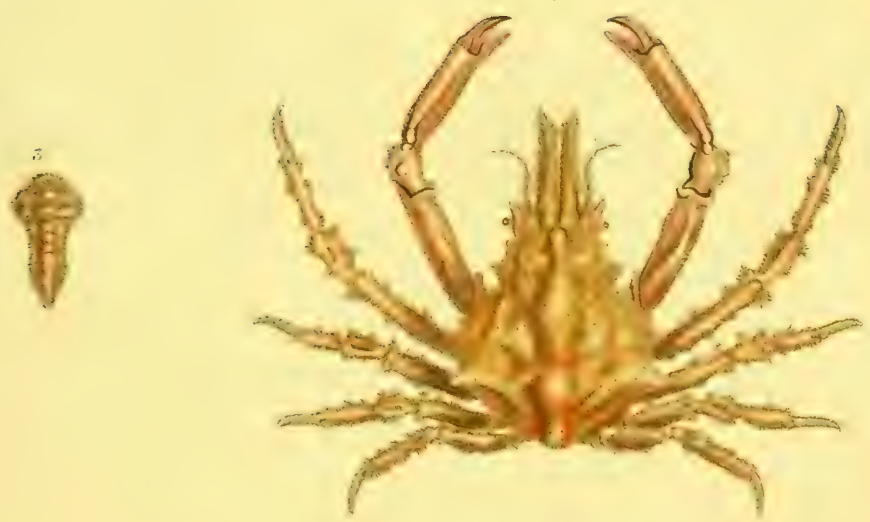

(1) 



\section{PISA TETRAODON.}

\section{TAв. XX.}

P. testâ lateribus utrinque 6-spinosis: spinis duabus minoribus; quatuor inajoribus.

Cancer tetraodon. Penn. Brit. ¿ool. iv. 7. tab. viii. fig. 15.

Maja tetraodon. Bosc, Hist. Nat. des Crust. 1. 254.

Leach, Edinb. Encycl. vii. 395.

Blastus tetraodon. vii. 43 ?.

Pisa tetraodon. Leach Trans. Linn. Soc. xi. 328.

\section{Encycl. Britan. Suppl. i. 415.}

Fig. 1. Pisa tetraodon mas. 2. Maris abdomen. 3. FEmina. 4. FGMine abdomen. 5. Antenna. 6. Pedipalpus externus.

This animal inhabits deep water on the coasts of the Isle of WVight, Brighton, and Teignmouth. It is often thrown on the shore after storms.

The arms of the young males are scarcely thicker than those of the adult female. 



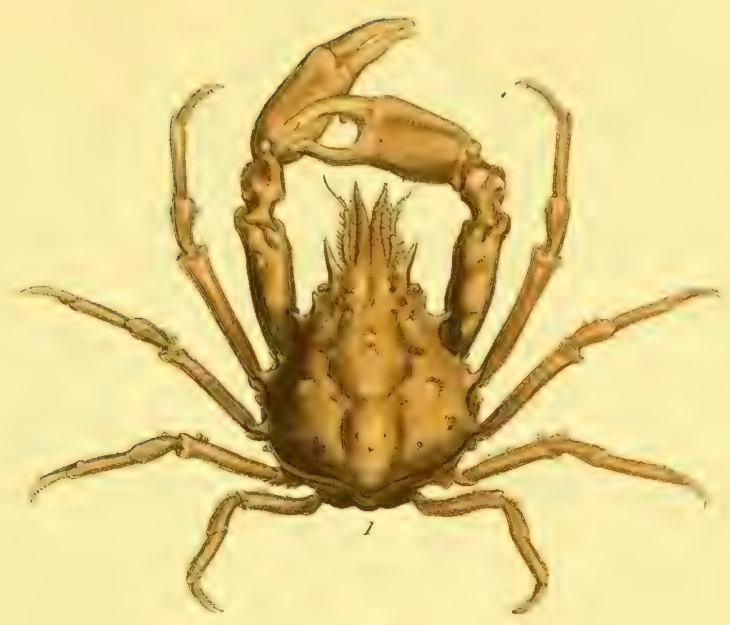

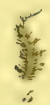
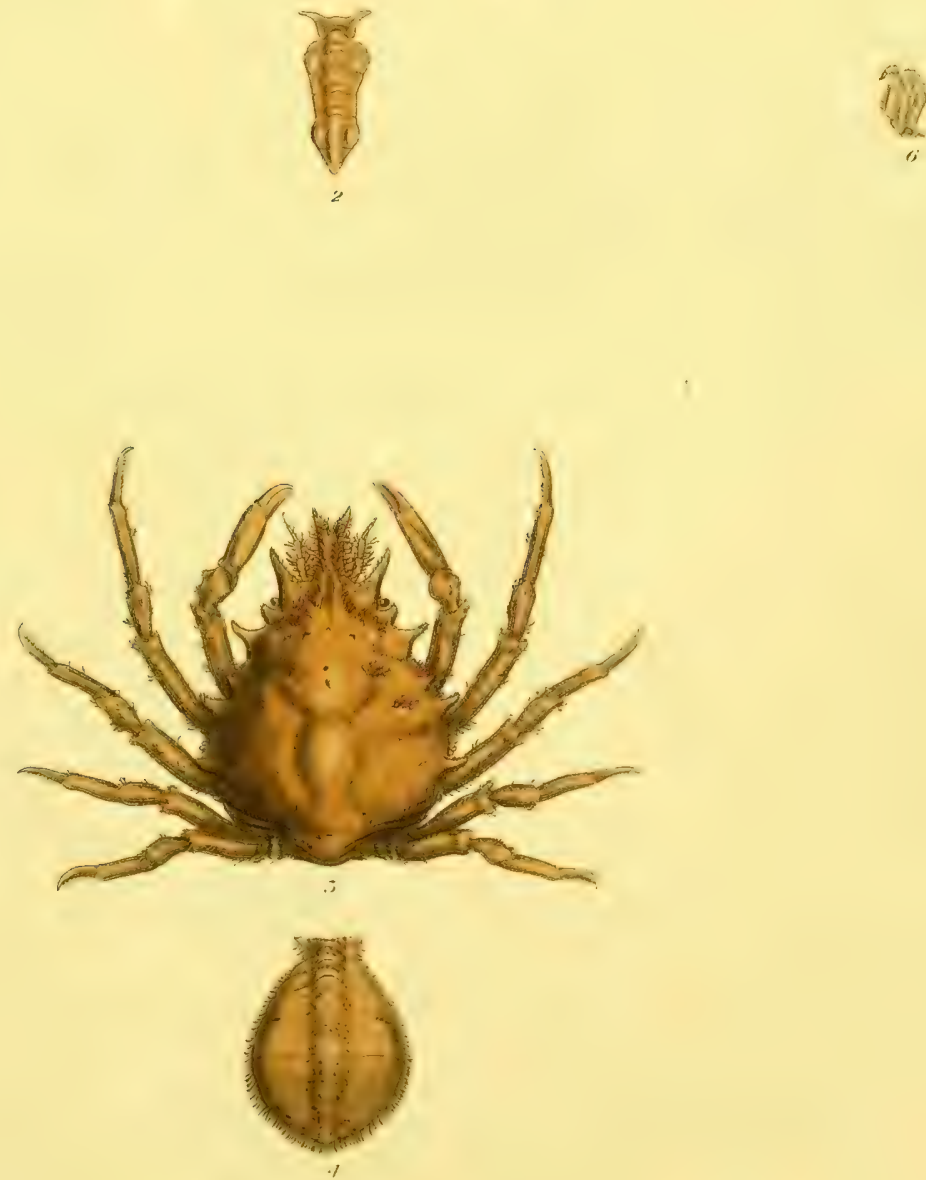



\section{HYAS.}

CANCER, Herbst.

MAJA, Bosc.

INACHUS, Fabricii.

HYAS, Leach.

Antennce externe distantes, articulo primo externè dilatato secundo longiore.

Pedipalpi cxterni, articulo secundo ad apicem internum emarginato.

Pedum par primum aliis crassius, didacțlum, acquale, mars corpore longius, Famer corpori, longitudine: paria alia elongata, simplicia.

Testu clongato-sulbtriangularis, subtuberculata, lateribus pone oculos hastato-productis, fronte rostrato; rostro fisso, laciniis approximatis.

Oculi pedunculo haud crassiores.

Abdomen 7 -articulatum.

External antenne distant, the first joint larger than the second, and dilated externally. External pedipalpes with the internal apex of the second joint notehed. First pair of legs thicker than the others, didactyle and equal; of the male longer than the body, of the female as long as the body. Shell elongate-subtriangular, slightly tuberculated, the sides behind the eyes with a spear-shaped process, the front rostrated, the rostrum fissured, the lacinia nearly parallel Eyes not thicker than the peduncle. Abdomen seven-jointed.

Of this Genus two species have been discovered in the British seas.

\section{MYAS ARANEUS. \\ Tав. XXI. A.}

II. testâ processu hastiformi posticè tuberculato.

Cancer araneus. Limn. Syst. Nat. i. 1044.

$$
\text { Fn. Sv. 493. } 2030 .
$$

Cancer Bufo. Herbst. i. 242. tab. xvii. fig. 59.

Inachus araneus. Fabr. Suppl. Ent. Syst. 356.

Maja Bufo. Bosc. Hist. Nat. des Crust. i. 255.

Maja araneus. Leach Edinb. Encycl. vii. 394.

Hyas araneus. Leach Edinb. Encycl. vii. 431.

\section{Trans. Limn. Soc. xi. 328.}

\section{Encycl. Britan. Suppl. i. 416.}

Fig. 1. Hyas araneus mas. 2. maris abdomen. 3. Feutre abdomen. 4. Antenna externa. 5. Pedipalpus externus.

This species of IIyas is rery abundant on the coasts of Scolland and of Kent. On the shores of Deronshire it is of rare occurrence.

The young is frequently found inhabiting pools of water amongst the rocks at low tide, and is often covered with fragments of marine plants, which adhere to the liairs of the leg- and shell : in this state it has been observed on the coast of Mernshire, near Montrose, by G. Milne, Esq. and on that of Kent, near Sandgate, by myself. 


\section{HYAS COARCTATUS.}

\section{TAB. XXI. B:}

H. testâ lateribus coarctatis, processu hastiformi poticè valdè dilatato inermi. Hyas coarctatus. Leach Trans. Linn. Soc. xi. 329.

Fig. 1. Hyas coarctatus Mas, 2. Fomina.

I discovered this species in the Frith of Forth, and on the southern coast of Devon, and I have received very fine specimens from a scientific friend, who took them off the coast of Kent, near Sandgate.

It is alivays found in very deep water, and is to be obtained by dredging. 

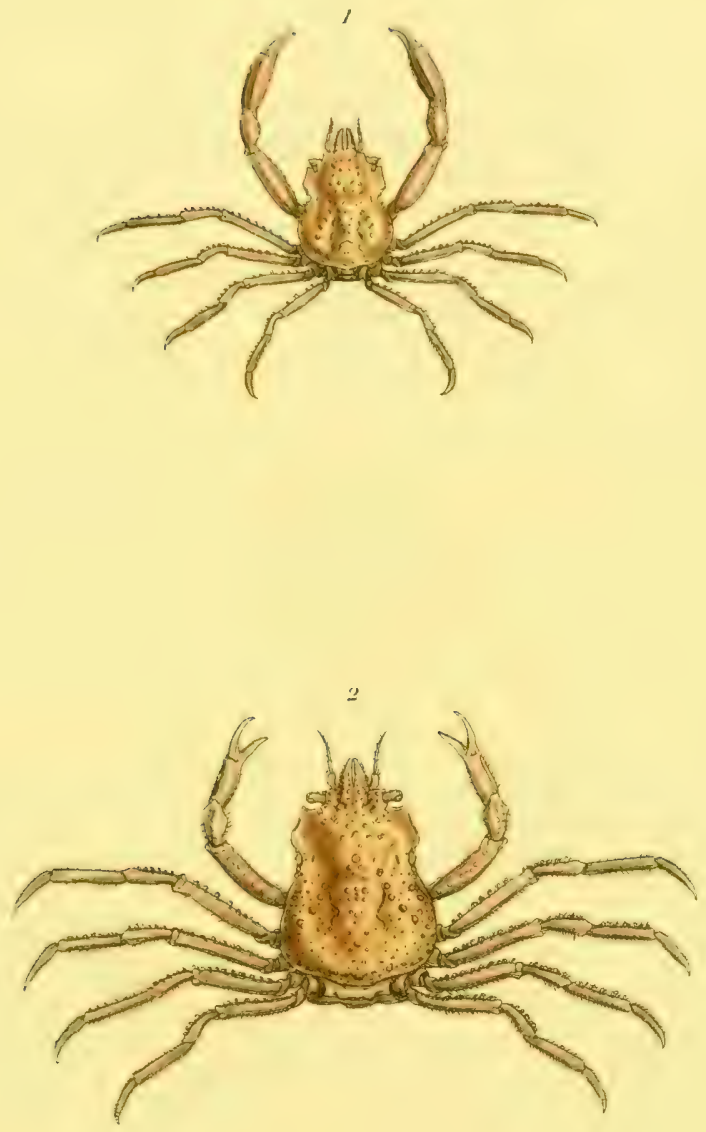


\section{INACHUS.}

CANCER, Pennant, Herbst, Gmelin.

INACHUS. Fabricius, Leach.

MAJA. Bosc, Latreille.

- Antchare catcrna distantes, corpore quintuplo breviores, sctacea, ante oculus ad rostri latcia inserta, articulis tribus basilaribus reliyuis distincte crassioribus.

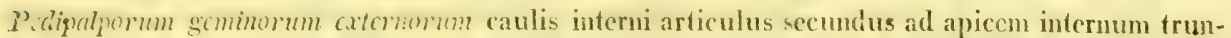
catus ad insertionem palpi clongato-subconici, triarticulati.

l'eclum par anticum majus, didactslum, aquale (maris corpore duplo longius, manu ovata ; Fenr $x$ corporis longitudine nanu subfiliformi : paria reliqua longissima tenuissima; pari secundo longiore, crassiore; tertio deinde, quarto postea, longioribus, quinto breviore. Lingues antici longiores subcurvati, secundi breviores magis incurvi, tertii et quarti secundis breviores, æquales, arcuati.

Tistt subtriangularis parce spinosa, antice rostrata, spina utrinque ad latera oculos retractos protegente; (orbitam quasi duplicem efformante).

Oculi distantes, pedunculi mediocris basi vix crassiores.

Aldomon 6-articulatum, longitudinaliter tuberculato-subcarinatum, articulo ultimo longiore:

MARIs articulis primo latiore, secundo breviore, angustiore, tertio primo latiore, quarto paululum angustiore, quinto et sexto abrupte angustioribus, loc ad basin subquadrato ad apicem abruptè angustiore arcuato:

Fenr.. articulis primo et secundo aqualibus, angustioribus, hoc cum reliquis conjunctis caudam latam, ovatam eftormantibus.

External antennx one-fifth of the length of the body, situated at a distance from each other on each side of the rostrum before the eyes, with the three first joints distinctly thicker than the others; second joint of the internal peduncle of the external double palpi truncated at its internal apex, for the insertion of the three-jointed elongate-conic palpus. Anterior pair of feet didactrle and large, equal in size and form (of the malc twice the length of the body with an oval hand; of the fimale the length of the body with a nearly filiform hand): other legs very long and slender, second pair longest and thickest, the second shorter, the third still shorier, the fourth shortest. Anterior claws long, slightly curved; third shorter, and more curved; fourth and fifth still shorter, arcuate and equal. Shell somewhat triangulate with few spines, anteriorly rostrated, with a spine on each side protecting the eyes when retracted, forming as it were a double orbit. Eves distant, scarcely thicker than the peduncle, which is of a moderate length. Abdomen six-jointed, with a kind of longitudinal tuberculated carina, the last joint longest; first joint in the male broader, the second shorter and narrower, the third broader than the first, the fourth a little narrower, the fifth and sixth abruptly narrower than the latter, nearly quadrate at the base, with the apex abruptly narrower and arcuate: the two first joints in the female equal and narrow, the latter joint with the others forming a broad ovate tail.

\section{INACHUS DORSETTENSIS. Tab. XXII. Fig. $1,2,3,4$, 5 , et 6 .}

1. Rostro brevi, emarginato, clypeo infra in spinam, producto: testa antice tuberculis quatuor parvis, aqualibus, transversim dispositis; deinde spinis tribus (antica dorsali validiore); postea spinis tribus validis, acutis (media sæpius majore, acutiore) lineam subrecurvar delinientibus; margine postico tuberculis duobus distantibus obsoletis. 
Cancer Scorpio Fabr. Sp. Tres. 1. 504. 47.

Mant. Ins. 1. 325. 77.

Herbst Krab. 1. 237. 130.

Gmelin Syst. Nat. 2978. 133.

Fabr. Syst. Ent. 2. 462. 83.

Inachus Scorpio. Fab. Supl. Ent. Syst. 35S. 16.

Inachus Dorsettensis. Leach Edin. Encycl. art. Crust. p. 131.

Fig. 1, mas. 2, feminx. 3, maris abdomes. 4, abdomen matur fenine. 5, abd. fene. immaturæ. 6, Pes anticus maris.

Rostrum short and emarginate, the clypeus beneath forming a susine; sleil belind the rostrum with four small equal sized tubercles placed transversely; behind these are plased three spines, the anterior or middle one strongest; behind these again are three other strong acute spines (the middle generally largest and sharpest), arranged in a slightiy recurved line; hinder margin with two distinct obsolete tubercles.

This species which is very abundant on the Devonshire coasts, was first described by Peurant from specimens in the Portland cabinet, and afterward by Fabricius as a native of the Corwegian seas, under the name Scorpio. Herbst and Gmelin never having seen this animal, have meiely copied the Fabrician description, which, in Entomologia Sestematica, is so good as to leave no doubt as to the reference. It is often taken by the shore net and dredge, at the mouths of rivers, and in deep water far from the shore; and is geneally overgrown with coralloils, sponges, or other marine matter. The anterior or compound feet in the male are often very rough with little spines and tubercles; and those of the female also exhibit slight vestiges of spinules. The siles of the shell are often tuberculated, especially anteriorly.

\section{INACHUS DORYNCHUS.}

\section{Fig. 7 et 8.}

1. Rostro hastiformi, fisso; testa anticc spinis tribus triangulum delinientibus, posticâ majore; deinde tuberculo utrinque; postea tuberculis quinque tribus mediis approximatus obtusioribus in triangulum dispositis pone lateralia et cum illis lineam retrorsum delinientibus; margine postico tuberculis duobus distantibus obsoletis.

Cancer Phalangium. Fabr. Ent. Syst. II. 463. 84?

Inachus dorynchus. Leach Edin. Encycl. art. Crust. p. 431.

Fig. 7, mas. 8, Ejusdem pes anticus.

Rostrum hastiform, fissured; anterior part of the shell with three spines placed in a triangle, the hinder one largest; then with a tubercle on each side; behind these with five tubercles, the three middle ones more obtuse, approximate and arranged in a triangle behind the lateral ones, and with them forming a line arched backwards; hinder margin with two obsolete distant tulsercles.

Like the foregoing species, it is generally overgrown with marine matter, which circumstance has doubtless concealed it from notice. I ciscovered the distinctions whilst cleaning a parcel of I. Dorsettensis from the Salcombe estuary for examination. The sides of the shell rarely exhibit any vestiges of spines or tubercles, and the compound feet are less rugose than in Derseitensie, indeed the hands are for the most part quite smooth. Like the foregoing species the shell is sprinkled with short yellowish or testaceons hair, which easily washes of with the IBysus; the lrands too are slightly covered with long hair. 

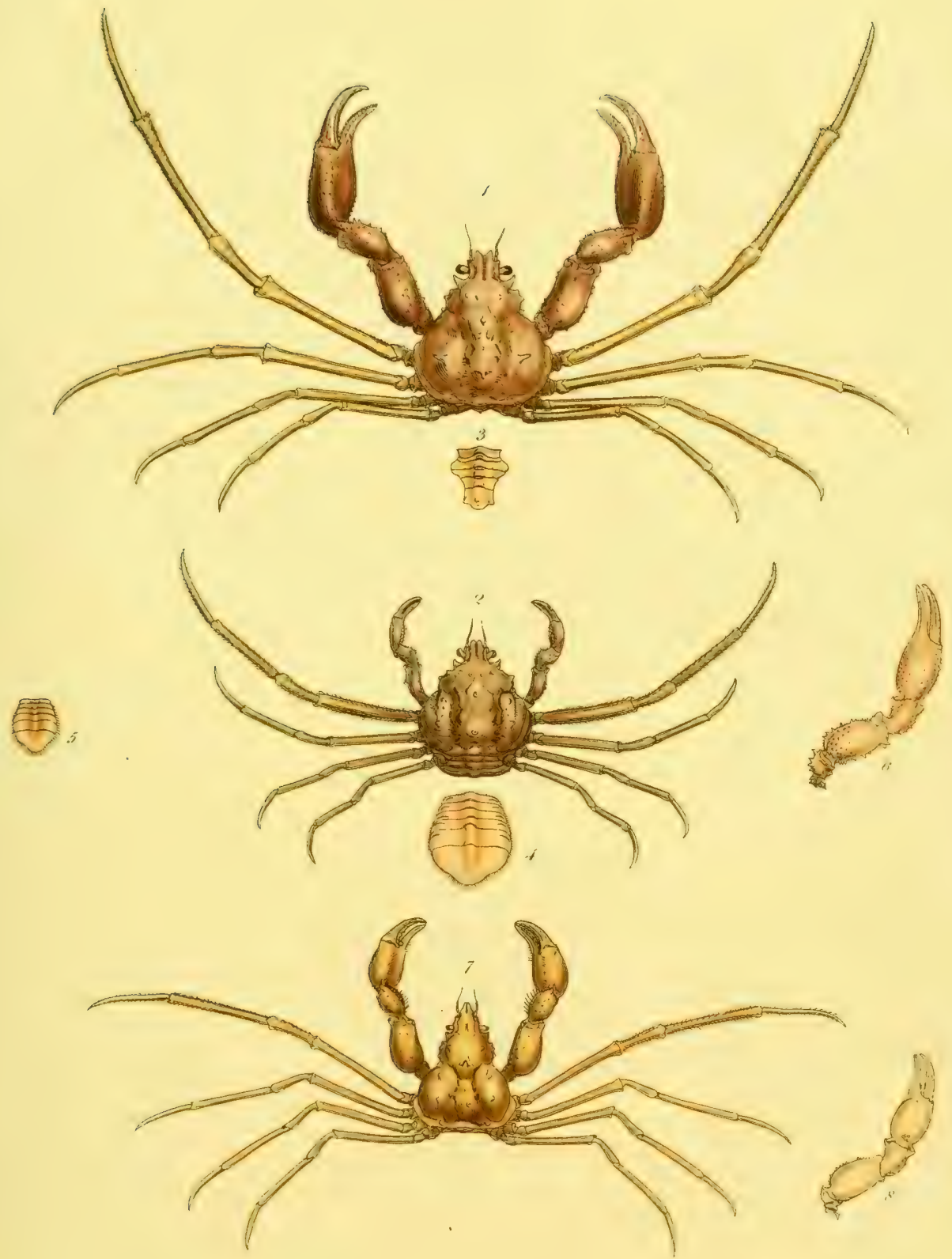



\section{INACHUS LEPTOCHIRUS.}

\section{'TAв, XXII.---в。}

I. manibus brachiisque in utroque sexu tenuilyus, rostro hastiformi, testâ anticè tuberculis duobus obsoletis cum spinâ triangulum delinientibus, deinde spinâ utrinque, postea spinis duabus in lineam subrectam digestis, (pectore maRıs inter pedes anticos elevato glaberrimo polito.)

Fig. 1, Inachus leptochirus vas mag. natur. 2. Maris abdomen auctum. 3. maris pectus mag. nat.

Mr. John Cranch discovered this species of Inachus on the Westem coast of Devon or Cornwall; and it has since been taken from a crab pot in Bigbury Bay, by C. Prideaux, Esq.

It is easily distinguished from Inachus Dorhynchus by its more slender arms, and by the number and disposition of the spines on the back. The tubercle also on the breast of the male is a very striking and curious character. 

. 


\section{ACH EUS.}

Antennce externce distantes setacex ante oculos ad rostri latera insertæ, articulis duobus basilaribus reliquis distincte crassioribus : secundo primo duplo longiore at tenuiore : articulis aliis elongatis.

Pedipalpi externi cauli interno articulo primo apice interiore valde producto: articulo secundo subtriangulato; angulis rotundatis.

Pedum par anticum majus didactylum; par secundum unguibus rectis; par tertium unguibus gradatim arcuatis ; paria quartum et quintum unguibus abrupte et valde curvatis.

Testa subtriangularis parce spinosa, antice breviter rostrata : rostro fisso.

Oculi distantes (pedunculi articulo secundo antice unituberculato) in orbitas haud retractiles.

Ablomen 6-articulatum tuberculato-subcarinatum.

External antenna wide apart, setaceous, inserted on the sides of the rostrum before the eyes: the two first joints distinctly thicker than the others; the second joint twice as long as the first, and more slender; the other joints elongate. The external pedipalpes with interior apex of their first joint very much produced; the second joint somewhat triangular; the angles rounded. Anterior pair of legs largest and didactyle; second pair with straight claws; the third pair with gradually curved claws ; the fourth and fifth pairs with the claws abruptly and much curved. Shell subtriangular, with few spines, anteriorly terminated by a short fissured rostrum. Eyes distant (with the second joint unituberculated in front) not retractile within the orbits. $\Lambda$ bdomen six-jointed, with a tuberculated keel.

The situation of Acheus, of which one species only has hitherto been discovered, is intermediate between Inachus and Leptopodia: it is the only known genus of the Brachyura, cxcepting the latter, whose eyes are not retractile.

\section{ACHEUS CRANCHII.}

\section{Taв, XXII.---c.}

A. testa medio tuberculis duobus; ordine 1, 1, et inter oculos lineis duabus elevatis.

Fig. 1., Achæus Cranchii fen. mag. nat. 2. Pedipalpus externus auctus. 3. Antenna exterior aucta. 4. Oculi articulus secundus amplificatus. 5. F(Emine abdomen auctum.

Mr. John Cranch discovered, by dredging off Falmouth, a single specimen of the female of this curious species, which from the developement of its abdomen is certainly adult.

Whether the tulercle in the second joint of the peduncle of the eyes, be a specific character only, or common to the whole genus, is extremely uncertain.

The legs are very liairy. 


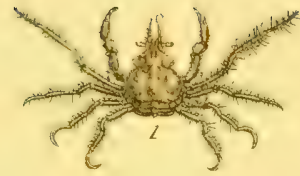

$\frac{1}{t}$
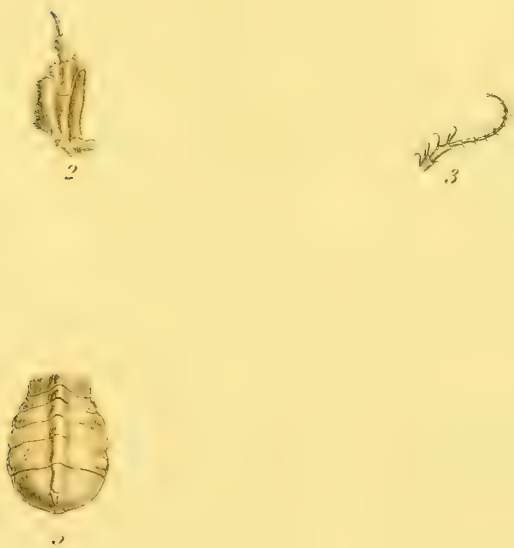



\section{MACROPODIA.}

\section{INACHUS. Fabricii.}

\section{CANCER. Herbst, Pennant, Villers.}

MAJA. Bosc.

MACROPUS. Latreille.

MACROPODIA, Leach.

Antenne crkime distantex, corporis dimidii longitudine setacex, ante oculos ad rostri latera inserta; articulo secundo primo triplo longiore.

Pidipalpi simini ancrni tenues caule intemo biarticulato, articulis longitudine subrqualibus; palpi triarticulati hirsutissimi.

Pedun par anticum mąu", didactulum, autale ( users corpore duplo longius; manibus elongatosuboratis, compreswis; curi, is manibus duplo brevioribus, angulatis; brcchiis manum

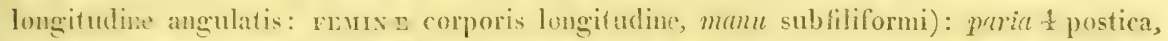
longissima, tenuisina : uns"us $\frac{1}{4}$ anfici ad apicem arcuati ; postici ad basin abrupte curvati. Testa subtriangularis parce spinosa, antice rostrata, rostro longo, fisso.

Oculi distantes, subreniformes, pelmenlo multo crassiores, in orbitas haud retractiles.

Abdomen 6-articulatum, tuberculato-subcarinatum:

Marrs articulo prino longiore, secundo angustiore, tertio posticé latiore, quarto angustiore, quinto ef sexto abrupte argusi ioribus, hôc al apicem abruptissimé angustiore, rotundato.

Fenix c articulis primo angustiore, aliis caudam ovatam efformantibus, ultimo ad apicem abrupté producto, rotundato.

External antemar distant, half the length of the body, setaccous, inserted at the sides of the rostrum before the eres; the second joint three times the length of the first. Extermal double palpi slenter, the internal footstalk two-jointed, the joints of nearly an equal length: palpi threejointed, and rerr hairy. Anterior pair of legs largest, didacty?e, equal of the male wice the length of tie body, the hauds clongate-suboval, compressed; wrists Inalf the lemgth of the hands, angulated; armis of the length of the hands and angulated: of the fomele as long as the body, the hand subiliform): four hinder pairs very long, very slender: four anterior claws bent at their tops; hinder claws abruptly bent at their base. Shall subtriangular, stub-pinose, rostrated in front, the rontrum long, cloven. Fyes chintant, subresiom, much thicher than their peduncles, not retractile within their orbits. Abcomen six-jointed, tuberculate-subearinated (of the male with the first joint laregest, the second narrover, the thind broaler behind, the fourth narower, the fifth and sisth abruptiy marower. the latter at its apex abruptly narrower and rounded: of the female with the first joint fuarrowest, the other joints forming an orate tail, the lant joint (with its anex abruptly produced and rounded).

There are but two species of this genus known, and with their habits I an macquainted. 


\section{MACROPODIA TENUIROSTRIS.}

\section{Tab. XXIII. Fig. 1, 2, 3, 4 , et $\mathbf{5}$.}

M. rostro longissimo tenui; antemis rostro sublongioribus; testa pone rostrum tuberculis duobus spinaque unica in triangulum dispositis; brachiis interné spinulosis.

Leptopodia tenuirostris. Leach Edinb. Encycl. vii. 431.

Macropodia tenuirostris. Leach Trans. Limn. Soc. xi. 331.

Fig. 1, Mas. 2, Maris abdomen. 3, Feminæ abdomen. 4, Feminæ pes anticus.' 5, Pedipalpus geminus externus.

I first observed this species amongst some crustacea collected at Torquay, in Southern Devon, by Hooker, and have since found it a very common inhabitant of all the deep water off the coast of that country, especially in the Sound of Plymouth.

It may be readily distinguished from the following species, by its spinulose arms, and long and slender rostrum.

\section{MACROPODIA PHALANGIUM.}

\section{FIg. 6.}

RI. rostro acuminato antemis multo breviore; testa pone rostrum tuberculis tribus triangulum delinientibus: postice majore; brachiis interne subscabrosis, hirsutis.

Cancer Phalangium. Penn. Brit. Zool, iv, 8.

Macculloch 'Trans. Linn. Soc. vi. 389. tab, 31.

Macropus longirostris, Latr. Gen. Crust. ct Insect. i. 39.

Maja Phalangium. Leach Edinb. Encycl. vii. 395.

- Zool. Miscel. ii. 18.

- Trans. Lim. Soc. xi. 331.

Leptopodia phalangium. Leach, Edinb. Encycl, vii. 431.

Fig. 6, Mas.

This species is very common in the mouths of rivers and in estuaries throughout the greater part of Britain, being well known by the popular appellation of Spider-crab. It las been observed by Dr. Nacculloch to be sometimes covered by fragments of a species of the Limnean genus Fucus, which are attached to its body and legs. 


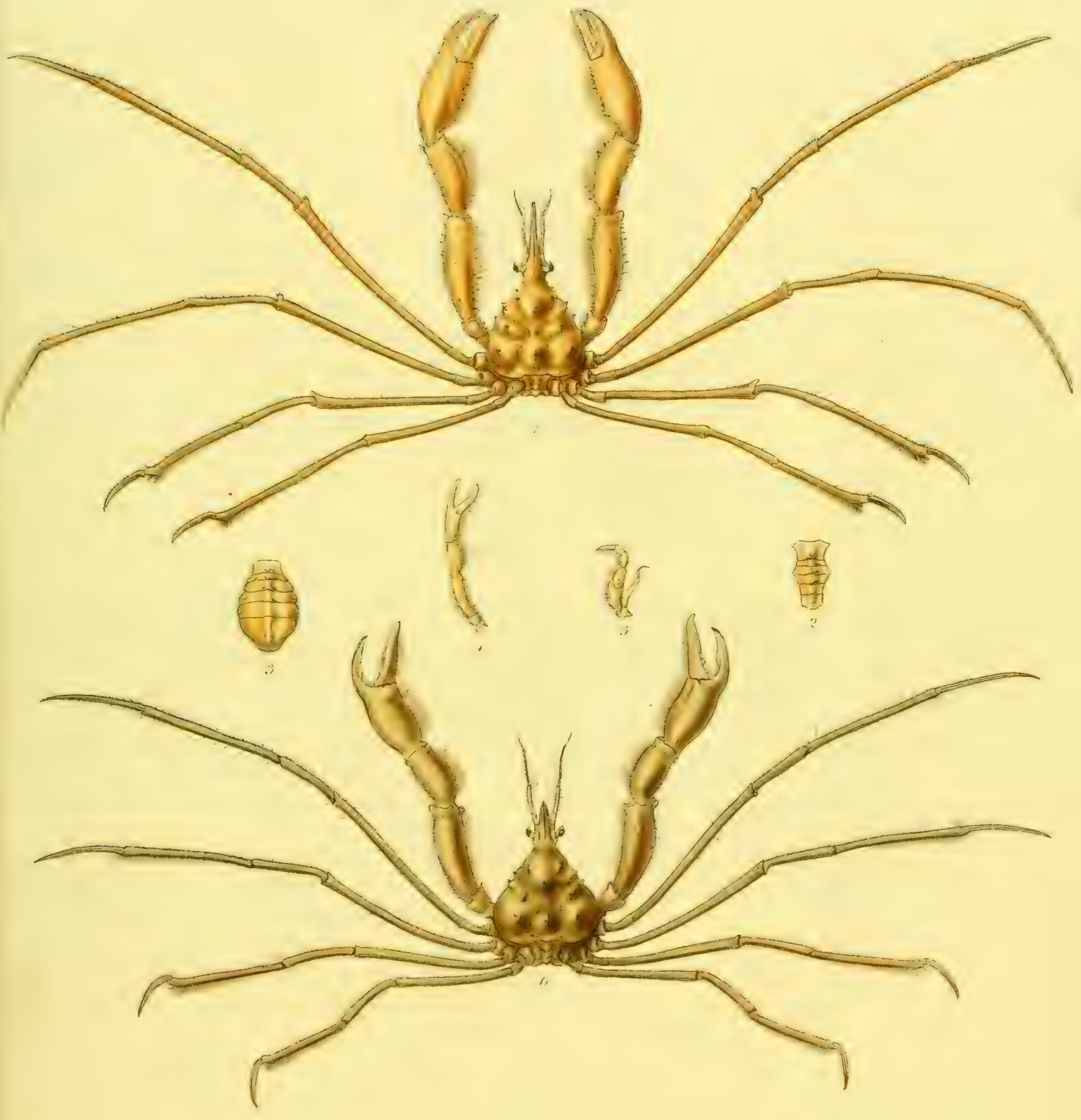





\section{LITHODES.}

\section{LITHODES. Latreille, Leach.}

MAJA. Bosc.

INACHUS. Fabricii.

CANCER. Linné, \&̊c.

Antenne externce corporis dimidii longitudine, setacex, sub oculos externé insertæ, spina ad basin exteriorem.

Internc porrectæ, elongatæ, setis duabus compressis, multiarticulatis instructæ.

Pedipalpi externi articulo secundo internè dilatato, denticulato.

Pedes decem ; par anticum inæquale, didactylum; digitis interne excavatis: paria 2,3 , et 4 , consimilia, ungue terminata; par posticum minutum, spurium, adactylum.

Testa triangularis, spinosissima, anticè rostro elongato, instructa.

Oculi ad basin approximati, pedunculo haud crassiores.

Abdomen (in utroque sexu?) membranaceum, squamis crustaceis; articulis primo et ultimo crustaceis.

External antennæ setaceous, half the length of the body, inserted under the cyes externally, with a spine at their exterior base; internal antennæ porrected, elongate, terminated by two compressed many-jointed setæ. External pedipalpes with the second joint internally dilated and denticulated. Legs ten: anterior pair unequal, didactyle; the fingers internally excavated; second, third, and fourth pairs alike, and terminated by a claw; hinder pair very small, spurious, and simple. Shell triangular, very spiny, anteriorly terminated by an elongate rostrum. Eyes not thicker than their peduncles, their bases approximating. Abdomen (in both rexes?) membranaceous, with crustaceous scales; the first and last joints entirely crustaceous.

The situation of this anomalous genus, which was classed with the MAJÆ by Lamarck, is extremely doubtful. In the form of its pedipalpes and external antennæ, and in the position of the eyes, it approaches the Macrourous Malacostraca. 


\section{LITHODES MAJA:}

\section{TAB, XXIV.}

1. rostro bifurco basi spinoso, digitis fasciculato-pilosis, abdomine basi spinoso.

Cancer Maja. Linn. Syst. Nat. 1. 1046. 41.

Fn. Sv. ed. 2. No. 2031.

Herbst 1. 219. Tab. 15. fig. S\%.

Cancer horridus. Penn. Brit. Zool. 4. 7. Pl. 7. fig: 14.

Inachus Maja. Fab. Suppl. Ent. Syst. 35ัS. 15.

Lithodes Arctica. Latr. Gen. Crust. et Insect. 1. 40.

Lithodes Maja. Leach Edin. Encycl. 7.

Trans. Linn. Soc. xi. 332.

Maia Araignée. Latr. Hist. Nat. des Crust. et des Insect. vi. p. 91.

Le Crabe epineux. Ascan. Icon. Rer. Natur. Tab. xxx.

Fig. 1, Lithodes Maja. 2, Pedipalpus geminus externus. 3, Pes posticus. 4, Abdomen.

Lithodes Maja inhabits the coasts of Aberdeen and Yorkshire; and has likewise been taken at the mouth of the Frith of Forth: it must, however, be considered as one of the rarer Crustacen of Britain, as it has no where occurred in any degree of plenty.

Notwithstanding the spines with which this animal is armed, it is sometimes deroured by the larger species of Gadus, and has been taken from the stomach of a cod by $\mathbf{P}$. Neill, Esq. S. II.S.

Colour, when living, flesh-red.

Seba in the third volume of his Thesaurus, tab. 1S. fig. 10. and tab. 22. fig. 1. has given gnood representations of this species, which, from the false references of Linné (Syst. Nat. 1. $104 \%$; have caused the erroneous synonyms of Pennant. who confounded it with Parthenope horrida* (Cancer horridus Linné); and this error, although repeatedly pointed out, has been continued in the new edition of Pennant's British Zoology.

* Vide Leach Zoological Miscellany, rol. ii. page $10 \%$. 


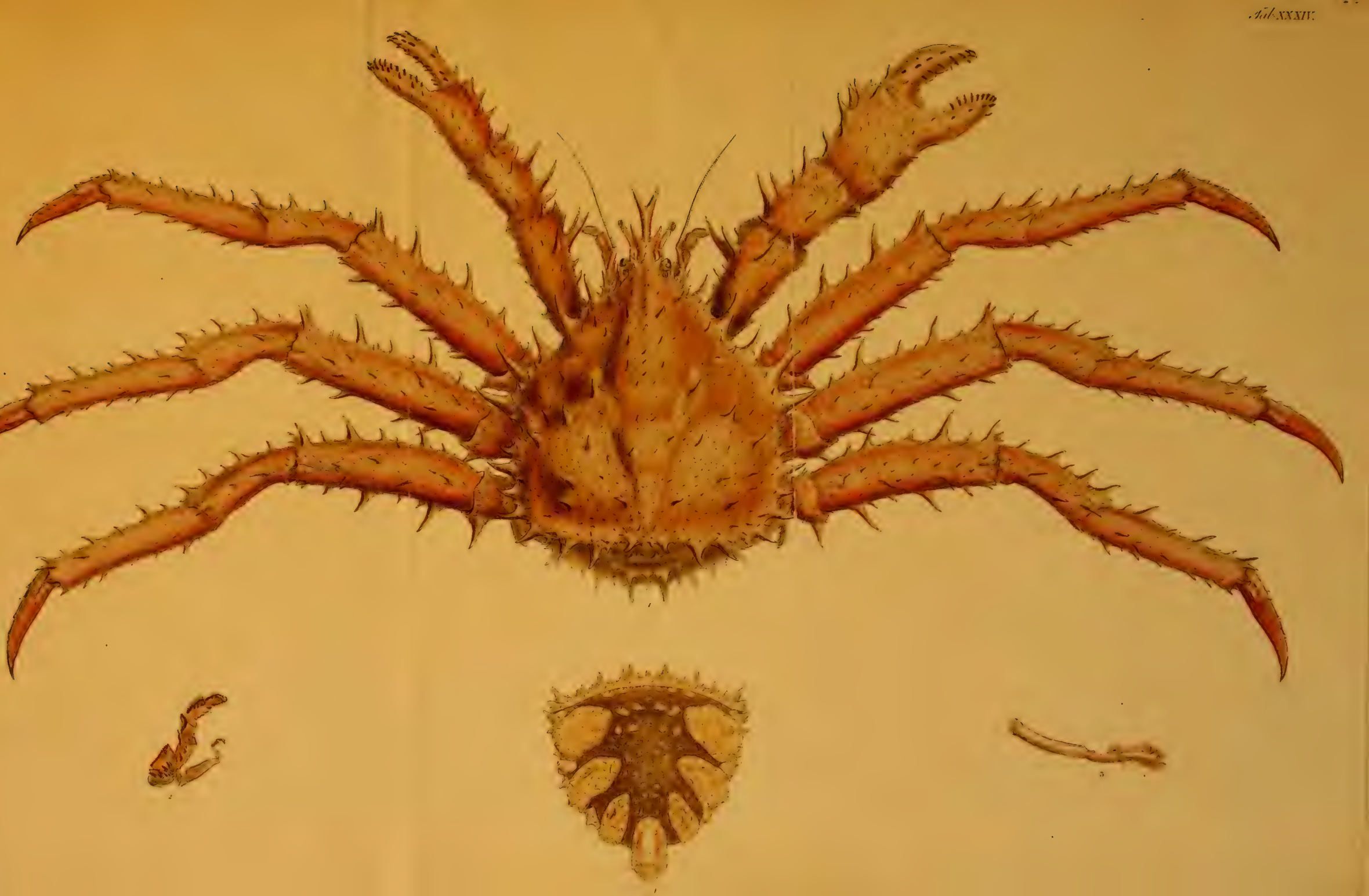





\section{DROMIA.}

\section{TAв. XXIV. A.}

\section{CANCER, Linncus.}

\section{DROMIA, Fabricius, Leach, Latreille.}

Antenne externe subtus oculi pedunculum insertie; tuberculo basali maximo, perforato.

Antennce internce articulo basali magno et ferè cylindrico; antemarum fossa longitudinales et distantes.

I'clum par anticum robustum, unguibus cochleariformibus valide dentatis; paria 4 et 5 parva, super dorsum teste reflexa et compressa, unguibus parvis duplicatis terminantes.

T'esta transversa, subglobosa, sublobata, tionte declinata, parva.

Oculi pedunculis brevibus.

External antennæ placed under the peduncle of the eye, with the basal tubercle very large, jerforated. Interior antenne with the basal joint large and almost cylindrical; the antennal pits me longitudinal and distant. The first pair of feet robust, with fingers spoon-shaped and strongly twothed; the and and 3rd single-clawed, and the 4th and 5th small, turned over the back of the carapace and closely pressed, terminating in small double-claws. Carapace transverse subglobose, with the front bent downwards and small. Eyes with short peduncles.

\section{DROMIA MEDITERRANEA.}

\section{Taв. XXIV. A.}

DROMIA MEDITERRANEA, Leach, Gray Zool. Journ. 1.p. 419.

CANCER DROMIA, Olive. Zool. Adr.p. 45.

\section{DROMIA RUMPHII, Bosc.}

1. testa subglobosa, rotundo-nodosa, latior quam longa, margine antico-laterali utrinque valide quadridentato; dente secundo basi tuberculato; abdomine maris articulo ultimo latiori quam longo, feminæ latissimo, valdè arcuato.

Fig. 1, Dromia Mediterranea. 2, Feminæ abdomen. 3, antenna externa. 4, antenna interna. 5 , pedipalpus. 6 , manus.

This very hirsute species frequently becomes covered with sponge, so that little of the shell is isille. Although long known as a Mediterranean Crab, its existence in our seas has only been recently discovered. The figure is taken from a large specimen, now in the British Museum, which was dredged off Penzance, and for some time lived captive in a tank. 

Tab. XYIV i

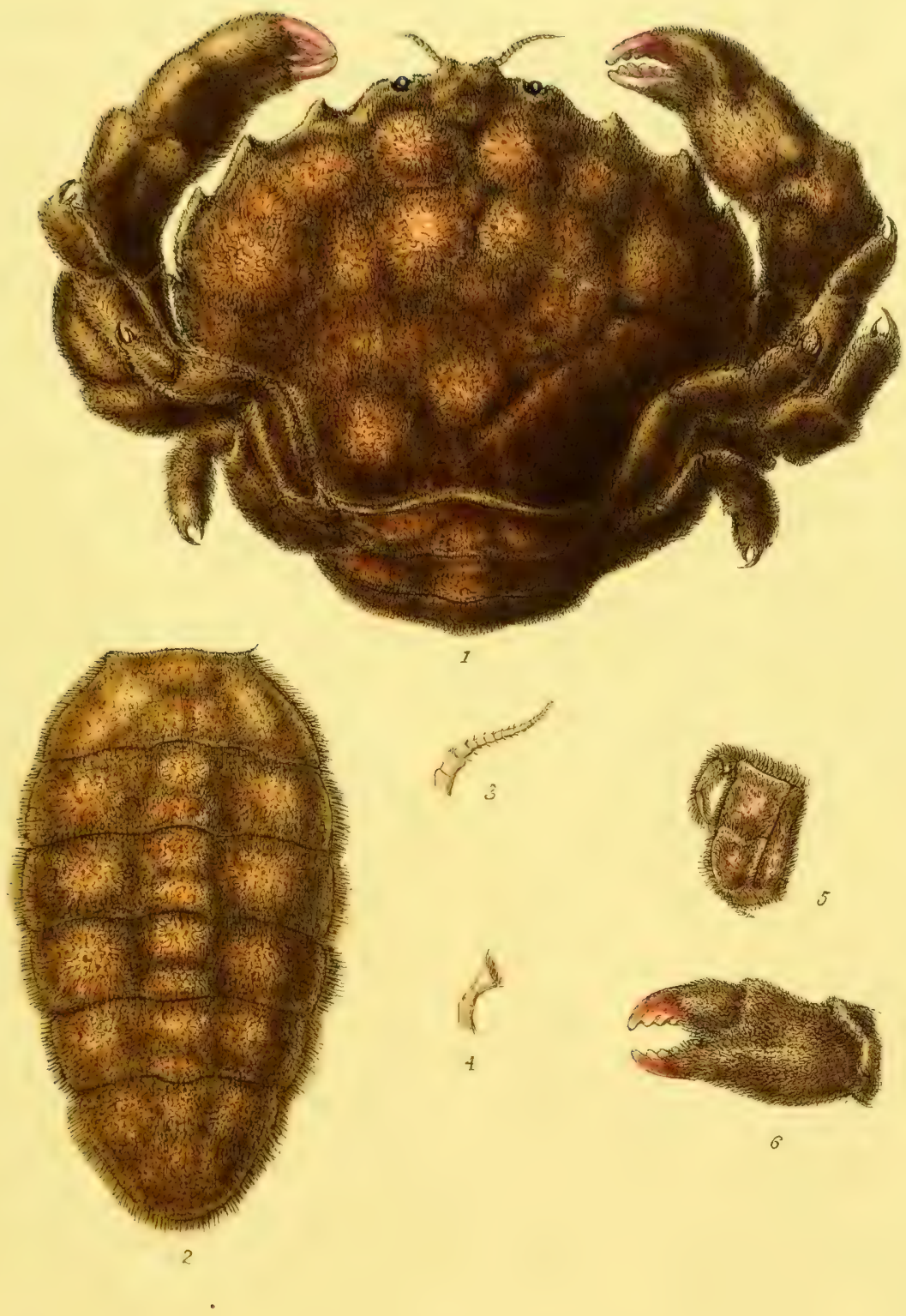




\section{EBALIA.}

CANCER, Pennant, Montagrı.

LEUCOSIA. Leach Trans. Linn. Soc. xi. 333. annot.

Antennc externce setacex minutissimæ in oculorum cantho interno inserta ; internce mediocres in foveolas obliquo-transversas inter oculos receptæ.

Pedipalpi externi cauli interno sensim acuminato, articulo secundo internè palpigero: cauli externo flagro nullo instructo.

Pedes decen ; par anticum majus equale depressum didactylum, brachiis subangulatis ; M.ıris illo FœMre longius; paria alia ambulatoria, ungue simplici instructa.

Abdomen 7 -articulatum, articulis mediis confluentibus; Maris angustum a segmento tertio sensin acuminatum, articulo ultimo basi unituberculato; røurs amplissimum medio latius, articulo ultimo parvo penultimo abruptè angustiore.

Testa rhomboidalis, lateribus integris, fronte subproducto.

Oculi minuti frontales.

External antennæ very minute, setaceous, inserted in the internal corner of the eye. Internal antenna moderate in size, received into oblique-transverse foreola between the eyes. External pedipalpes with their internal footstalk gradually acuminated; the second joint internally palpigerous : external footstalk without the usual appendage. Legs ten ; anterior pair largest, equal, depressed, didactyle, with the arms somewhat angulate; of the male longer than that of the female; other pairs formed for walking and terminated with a simple claw. Abdomen seven-jointed, the middle joints confluent; of the male narrow, gradually acuminated from the third joint; of the female very large, broader in the middle, with the last joint small and abruptly narrower than the preceding joint. Shell rhomboidal, with the sides entire and the front slightly produced. Eyes minute, frontal. 


\section{EBALIA PENNANTII.}

\section{$\mathrm{T}_{\mathrm{AB}}$. XXV .--Fig. 1---6.}

E. testâ granulatâ cruce irregulari elevatâ, abdomine articulis $3-6$ coalitis.

Cancer tuberosus. Penn. Brit. Zool. iv. 8. tab. 9. A. fig. 19.

Fig. 1. Ebalia Pennantii mas. 2. maris abdomen auctum. 4. Pedipalpus auctus. 5. Ebalia Pennantii fømina, 6. ғжminæ abdomen ampl.

Pennant first described this species from the Portland cabinet: it is occasionally taken by dredging off the Dentridge, near the Saltstone, in the Estuary of Kingsbridge, from whence I have received several specimens, and possess one imperfect female half as large again as fig: 5 .

\section{EBALIA CRANCHII.$$
\text { ТАв: XXV.---Fig. 7---11. }
$$

E. testâ subgranulatâ carinatâ tuberculis quinque; ordine, 2 aproximatis, 2 distantibus, 1 medio majore, abdomine maris articulis $3-5$, femince $4-6$ coalitis.

Fig. 7. Ebalia Cranchii sas. 8. Ejusdem abdomen. 9. E. Cranchii faenina. 10. Fanise abdomen. 11. E. Cranchii mas, junior.

This species was discovered by that enterprizing naturalist, Mr. J. Cranch, (whose death in the late expedition to Congo, has been so much lamented by naturalists), in the Sound of Plymouth, where Mr. C. Prideaux has likewise observed it, in considerable plenty, and has supplied my collection with a complete series.

\section{EBALIA BRYERII. \\ TAB. XXV..-Fig. 12---13.}

E. testâ læviter granulatâ anticè subcarinatâ tuberculis tribus ordine 2,1 ; (famince tumidis), abdomine maris articulis $3-5$ et $6-7$, fomince $4-6$ coalitis.

Cancer tuberosa. Mont. Trans. Linn. Soc. ix. 86. tab. 2. fig. 3. foem. aucta.

Brachia Maris illis E. Cranchii breviora ; carina dorsalis inter tubercula antica uni-tuberculata.

Fig. 12. E. Bryerii femina. 13 fomiñ abdomen.

Montagu received this species from Mr. Bryer, who took it at Weymouth. I have obtained it from the Sound of Plymouth, through the liberality of Mr. C. Prideaux. I have seen but one male, which differs from the female in not having the dorsal tubercles tumid. 

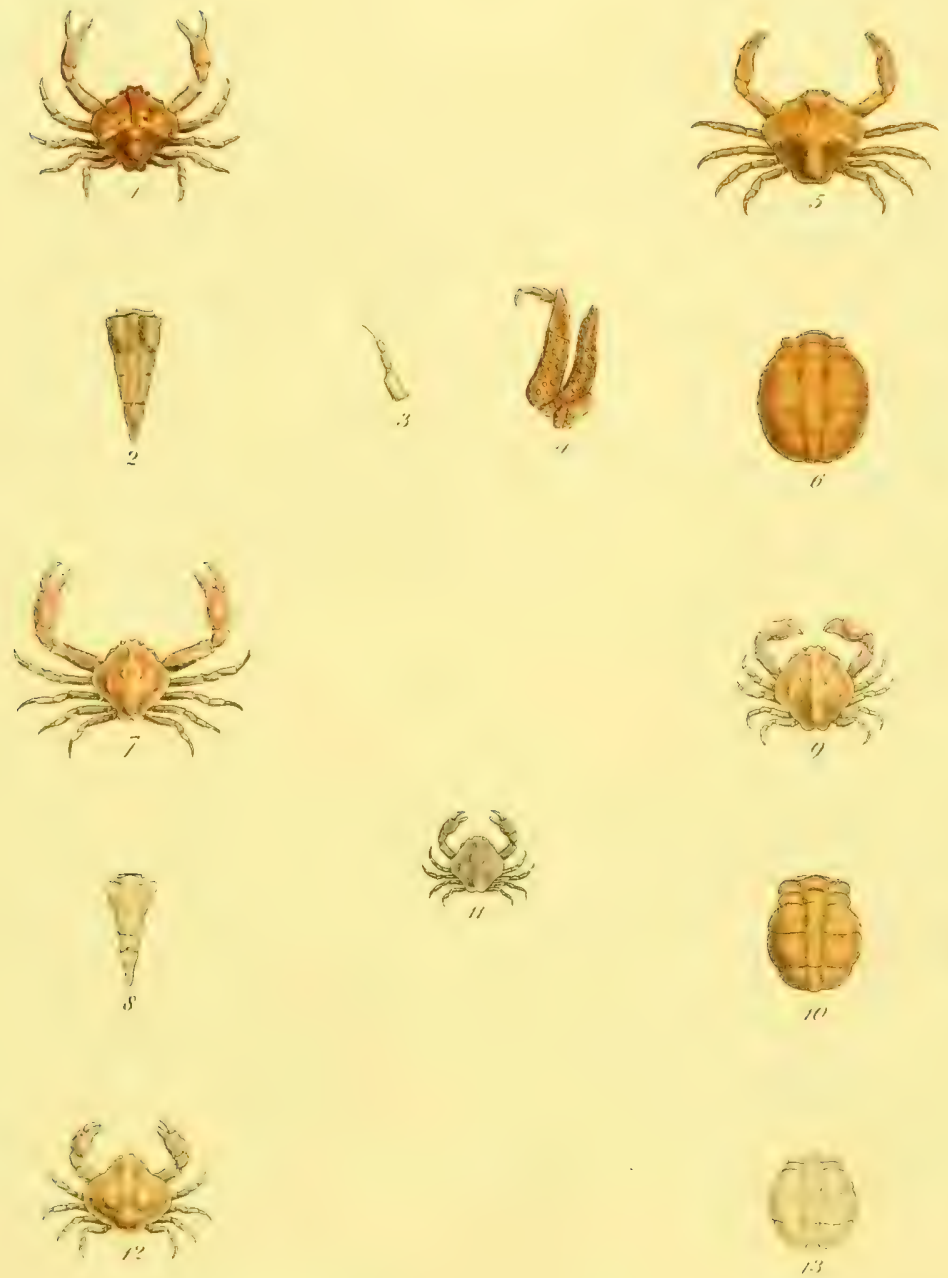



\section{PAGURUS.}

PAGURUS. Fabr., Bosc, Lam., Latr., Leach.

AST ACUS. Pennant.

CANCER. Limné.

Antenne intriores breviores, setis duabus articulatis; inferiore breviore, filiformi; superiore conpressâ subconicâ infra pilosâ, pedunculus triarticulatus, articulo tertio longiore:

cxtcriores setacex longissimæ multiarticulatæ; pedunculus 4-articulatus, articulo secundo ad apicem supra spinâ mobili instructo.

Pcdipalpi gomini cxterni cauli interno articulis quinque exsertis ; articulis 1 et 3 brevioribus. 2 et 4 longioribus longitudine subaqualibus.

Oculi frontales, spinâ mobili supra ad illorum basin.

Ptdes decen; par anticum valdè inæquale, majus, didactylum; digitis fasciculato-pilosis ; paria 2 et 3 elongatis, aqualibus unguibus elongatis subcurvatis instructa; paria 4 et 5 abbreviata, subcrustacea, pilosa, didactyla.

Thorax membranaceus anticè suprà clypeo crustaceo instructus.

Abdomen membranaceum exarticulatum, elongatum, molle.

Cauda triarticulata, crustacea, articulo secundo utrinque appendiculato.

Interior antenna shortest, with two articulated seta; the lower seta shortest, filiform; the upper one compressed, subconic hairy beneath; peduncle three-jointed, the third joint longest : cxtcrior antenna setaceous, very long, composed of many joints; peduncle t-jointed, the second joint with a moveable spine at the upper part of it s extrenity. Extcrud fictpalyes with their internal footstalk having five exserted joints, the first and third joints shortest; the second and fourth longest and of equal length. Eyes situated in the front, with a moveable spine at the upper part of their bave. Leg's ten; anterior pair very unequal, larger than the rest, didactyle, the fingers with tufts of hair; second and third pairs of equal size, elongate, with subcurved elongate claws; fourth and fifth pairs short, subcrustaceous, hair, didactrle. Thorax membranaceous, with a crustaceous shield on its anterior part above. Abdomon without joints, elongate, membranaccous, soft. Tail triarticulated, crustaceous, the second joint with appendices on each side.

The animals of this menus are commonly denominated Soldicr, or Hermit-crabs. Their conomy is extremely curious and interesting, and so much so as to have attracted the attention of ancient naturalists; one species is described by Aristotle under the title rapruray.

All the species are paracitic, and inhabit the casities of turbinated shells. They change their habitation curing their growth, fist occupving the smallest shells, and latterly these of considerable dimensions. They adhere to the pillars of the sinells by the appendices situated on either side of their tail : and move about with great facility, dragging the sliels after them. 


\title{
PAGURUS STREBLONYX.
}

\section{Tab. XXVI. FIg. 1 ad 4.}

P. manibus fortiùs granulatis ; carpis supra, brachiis apice pedibusque secundis tertiisque supra spinosis; unguibus tortuosis, supra spinosis.

Fig. 1, Pagurus Streblonyx. 2, antenna interior aucta. 3, antenna exterior aucta. 4, pedipalpus aucta.

This is the common soldier-crab of our seas. It inhabits almost all of the univalves that are found on our coasts. The right claw is generally but not always the largest, as I have seen a specimen in which the contrary was the case.

It is generally placed in British collections as Cancer Bcrnhardus of Linné, but I cannot venture to affix any synonym to it, as the descriptions of authors are too general, and many species agreeing with their characters are found in the European Ocean.

The twisted claws distinguish this from all the other species which I have yet seen.

\section{PAGURUS PRIDEAUX.}

\author{
FIg. 5 et 6.
}

P. manibus granulatis; carpis angulo interno spinosis; brachiis apice spinulosis; pedibus secundis et tertiis obscurè submuricatis ; unguibus tenuibus, supra subserratis.

Fig. 5, Pagurus Prideaux. 6, in Scaphandre lignario.

Pagurus Prideaux inhabits the sea on the southern coast of Devon, and is most common in the Sound of Plymouth.

It is named after C. Prideaux, Esc. by whose friendly assistance in sending me a good series of specimens I am enabled to ascertain that it is distinct from the preceling species.

Mr. Prideaux has observed it in a vast variety of habitations, even in the tubes of the Dentalia, and in the shell of Scaphander lignarius. 
Talixyt.

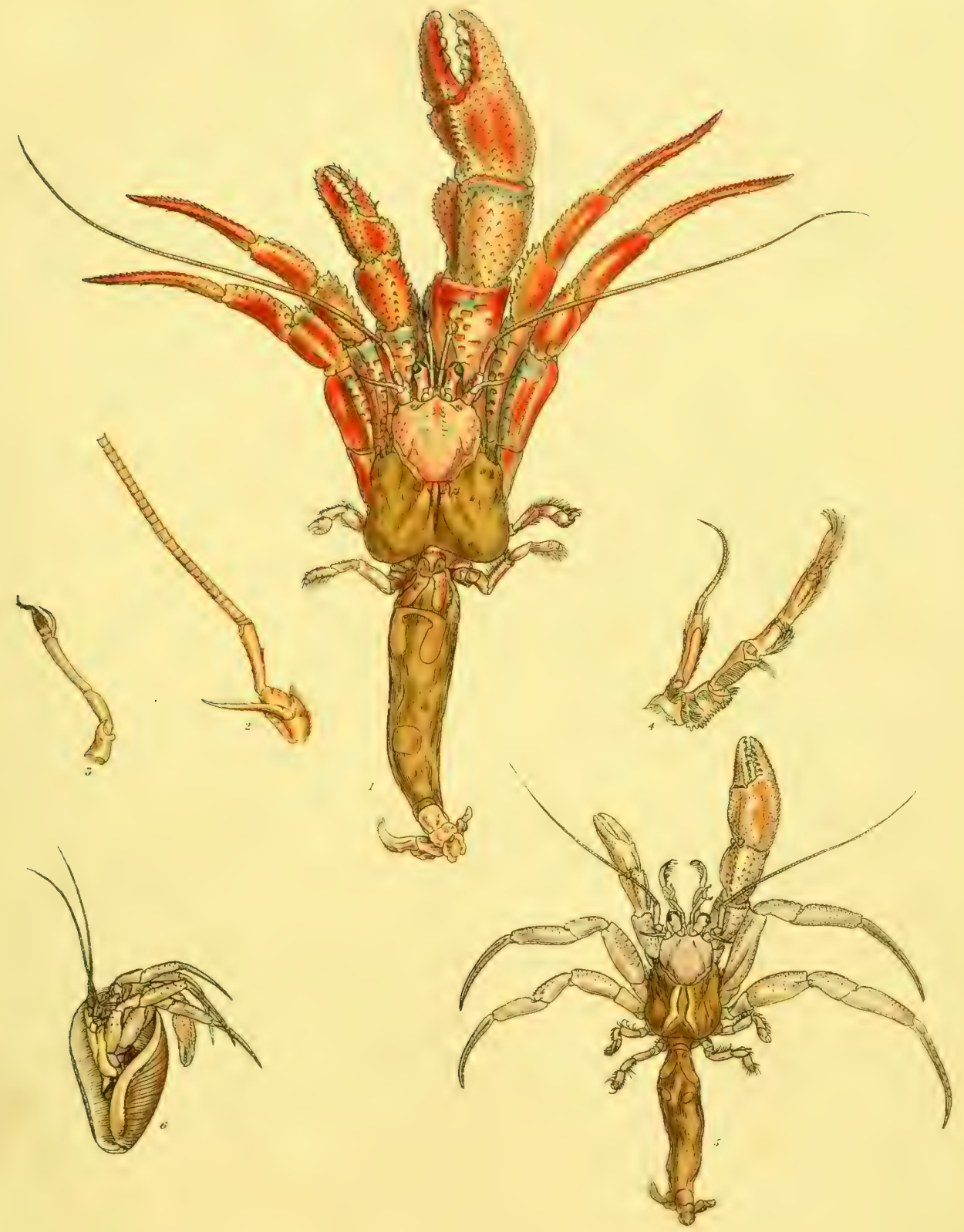




\section{PLANES.}

CANCER, Herbst.

GRAPSUS, Latreille.

PLANES, Leach.

Testa depressa, convexa, rotundato-subquadrata.

Antenna externce extus fossas antennarum insertæ.

Antennoc internce in fossas transversè plicatre.

Pedipalpi externi articulo tertio latiori quam longo.

Pedum par anticum robustum, manu inflato, digitis inflexis, leviter dentatis.

Oculi distantes, pedunculis elongatis.

Abdomen utroque sexu septem-articulatum.

Carapace depressed, convex, roundly-subquadrate. External antennre placed outside the antemnary grooves. Internal antemne folded transversely in the groove. External pedipalps with the third joint broader than long. First pair of feet robust, the hand inflated, fingers curved inwards and slightly toothed. Eyes distant, with long peduncles. Abdomen seren-jointed in each sex.

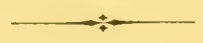

\section{PLANES LINN EANA. \\ TAB. XXVII. FIG. $1-3$.}

I'. testa subquadrata, medio depressa, lateribus rotundatis, posticè striatis; fronte lata, producta integra; orbitis distantibus, utrinque ad angulum testæ locatis, margine externo unidentato; pedibus anticis robustis, subrequalibus.

Cancer minutus, Fabricius, Syst. Ent. XL, p. 443.-Herbst.

Planes Linnæana, Leach.

Fig. 1, Planes Linnæana. 2, maris abdomen. 3, feminæ abdomen.

This species principally inhabits the coasts of Devon and Cornwall. 
Tab. $x 1 v ! n$

$\vec{E}$
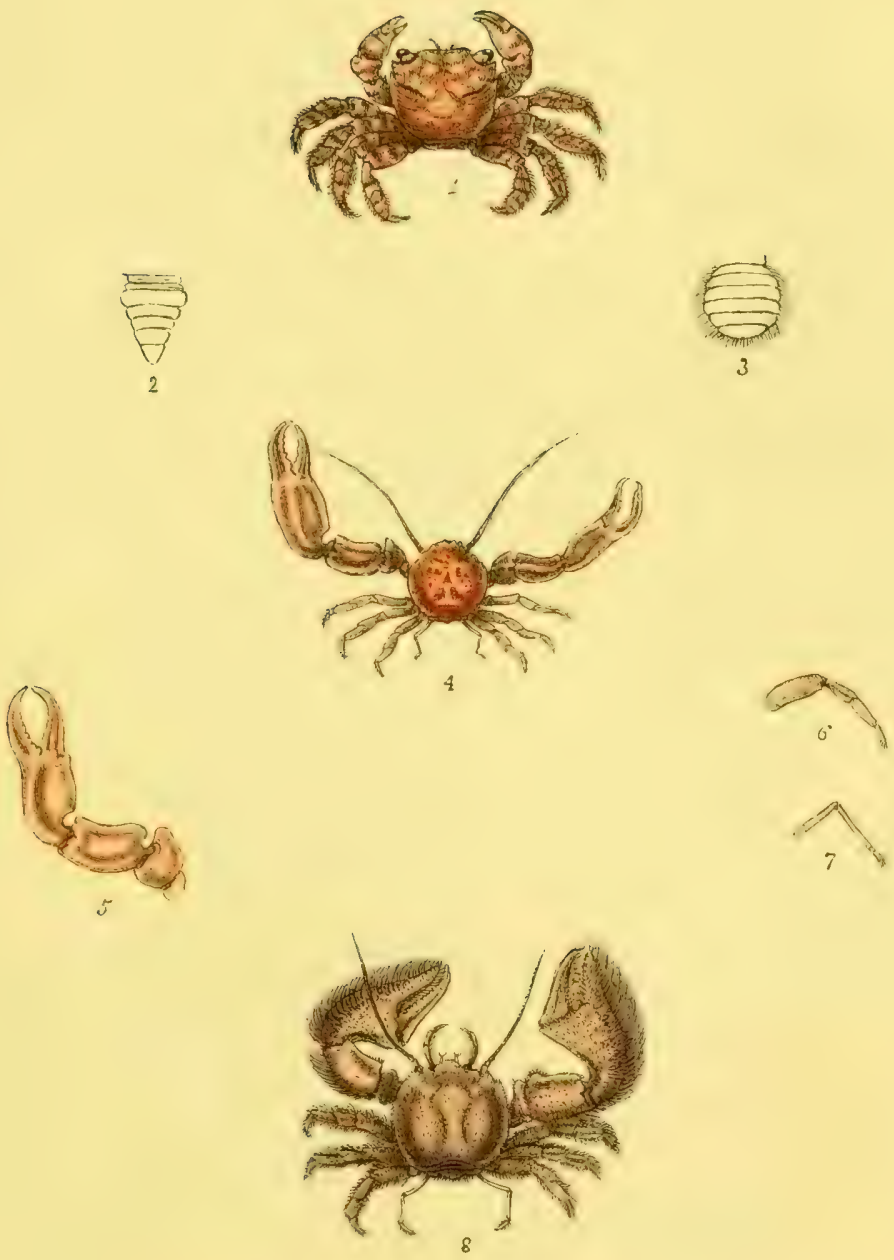



\section{PORCELLANA.}

CANCER, Pemant.

PORCELLANA, Lamarch, Leach.

Antennce externce extus oculos insertre.

Antennce internce parvæ, subtus frontem obtectæ.

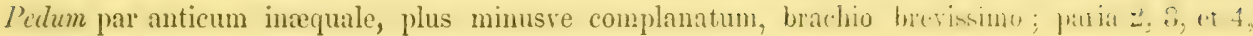
ambulatoria, monodactyla; par. 5, minutum, didactyle.

Iesta suborbicularis, depressa.

Oculis minutis.

Abdomen maximum.

External antenne inserted outside the eyes. Internal antemax small, hidden heneath thic fore-head. First pair of feet very large, unequal, more or less flattened, with rery short arn; second, third and fourth pairs ambulatory, terminating in a single finger'; fifth pair rery small, didactyle; eyes very small. Abdomen very large.

\section{PORCELLANA LONGICORNIS.}

\section{TAB, XXVII. FIG, 4-7.}

I'. testa suborbiculari, fronte trilobata, loba media profunde unisulcata; manibus inequalibus, elongatis, angustis, extus convexis.

Cancer longicornis, Pennant, Brit. Zool. IV.

$$
\text { Herbst, II. t. XLVIII. }
$$

Pisidia et Porcellana Linnæana. Leach, Dict. Sci. Nat. XVIII.

Porcellana Leachii. Gray (Postea.)

Fig. 4, Porcellana longicornis. 5, manus. 6, 7, pedes quartum et quintun.

The colour of this species is generally pale red, with deeper markings. The characters of the hands, wrists and arms, distinguish it very decidedly from P. platycheles. It is common on the British coasts, being dredged in the oyster nets very abundantly in some localities. 


\section{PORCELLANA PLATYCHELES.}

\section{TAB. XXVII, Fig. 8.}

P. fronte dentilus tribus, complanatis, trigonis, mediano productiori, manibus maximis, unguibus

trigonis; carpo infrà loba dentata armata.

Cancer platycheles, Pemant, Brit. Zool. IV. pl. VII. Merbst, t. II. f. 6.

Porcellana platycheles, Leach, Dict. Sci. Nat.

Fig. 8. Porcellana platycheles.

This curious little crab is quite littoral in its habits, being found under stones at low water in many parts of our coast. If seized by its claws, it makes no difficulty of jerking them off for the purpose of escaping. 


\section{GALATHEA.}

\section{CANCER. Linn., Gmel.}

\section{ASTACUS. Johnst., De Geer, Pennant.}

\section{GALATHEA. Fabricii, Daldorf, Lamarck, Bosc, Lalreille, Leach.}

Antenna extcriores corpore longiores segmentis basilaribus tribus crassioribus, secundo haud longiore quam latiore;

Interiores pedunculo elongato infra oculos inserte segmento ultimo acuto multiarticulato infra ciliato, setâ articulatâ ad basin.

Pidipalpi gemini externi 5-articulati, articulo primo interne haud dilatato.

Pides decem; par anticum aquale, crassius, didactylum indice ad apicem saltem dentato; paria 2,3 , et 4 simplicia consimilia, subcompressa, unguibus acutis instructa; par quintum brevius spurium articulo ultimo inermi, ciliato.

Abdomen 6-articulatum.

Cauda pentaphylla; processibus medio fixo e segmentis composito, duobus externis simplicibus mobilibus.

\section{GENERIS DIVISIONES.}

* Rostrum acuminatum acutum utrinque 4-spinosum (spinâ posticâ minorc). Pedes antici compressi. Abdomen scgmentis latcraliter obtusis. Cauda lamolla intermcdia triangulari apice cmarginato laciniis apice rotundatis.

a. Antenna interiores 4-articulata articulo primo apice unispinoso, pedunculo apice bispinoso. Pedipalpi gemini externi cauli interno articulo secundo primo longiore.

b. Antenna interiorcs 3-articulata, pedunculo trispinoso. Pedipalpi gemini externi cauli interno articulo primo secundo longiore.

** Rostrum elongatum spiniforme basi utrinque bispinoso (spinâ posticâ minorc). Pedes antici subcylindrici. Abdomen segmentis lateraliter acutis. Cauda lamclla intermadia transversoquadrata apice subcmarginatô.

(Antcme interiores triarticulate, redunculô 3-spinosô. Pcdipalpi gemini cxterni cauli intcrno articulo primo secundo longiore.)

External antenna longer than the borly, with the three first segments thicker than the others, the second not longer than broad; internal antema with an elongate footstalk inserted beneath the eyes, their last joint acute composed of many segments, ciliated beneath, with an articulated seta at its base. External double feet-palpes five-jointed, the first joint not dilated internally. Legs ten ; anterior pair didactyle, equal in size and thicker than the other legs ; second, third, and fourth pairs simple, alike in form, somewhat compressed, with acute nails; fifth pair shorter, spurious, the last joint simple ciliated. Abdomen six jointed; tail composed of five foliaceous processes, the middle one of which is fixed and composed of several pieces, the nuter ones being moveable. 


\section{DIVISIONS OF THE GENUS.}

* Rostrum acuminate, sharp with four spines on cach sidc (hinder spine smallest). Antcrior lcgs depressed. Abdomon with the sides of the scgments obtuse. Tail with the middle process triangular, the tip emarginate with the lacinice rounded.

a. Internal antennce four-jointed, the first joint with its apcx one-spined, the tip of the pcduncle being two-spined. External double feet-palpes with the sccond joint of the internal stalks longer than the first.

b. Internal antenna three-jointed, their peduncle with thre spines. Extcrnal double fect-palpes with the second joint of the internal stalks shorter than the first.

* Rostrum clongate spine-shaped with two spines on cach side of its basc (hinder spine smallest). Anterior legs somewhat cylindric. Abdomen with the sides of the segments acute. Intermcdinte lamella of the tail transverse-quadrate, the tip slightly notched.

(Interior antennce three-jointed, peduncle with three spincs. Extcrnal double fect-palpes with the second joint of their internal stalk shorter than the first.)

The Galather inhabit deep water, and are for the most part found on rocky coasts. Ther move with very great rapidity, and when taken violently flap their breast with their abdomen.

Johnson has figured three species of this genus. (Historia naturalis de cxanguibus, lab. 2. fig. 3. 7. ct tab. 4. fig. 11.)

\section{GALATHEA SQUAMIFERA. \\ Taв. XXVIII. A.}

G. (* a) Pedibus anticis granulato-squamosis, manibus externe, carpis brachiisquue interne spinosis.

Cancer astacus squamifer. Montagu MSS.

Galathea squamifera. Leach Edin. Encycl. 7. p. 398.

Fig. 1, Mas adultus. 2, Mas junior. 3, Pedipalpus geminus externus panlulum anctus. 4, Pedum tertii paris basis. 5, Feminx pars eadem coxa perforationem exhibeus. 6, Maris pes posticus coxâ perforatâ. 7, Pes posticus Femina. 8, Abdominis segmenti secundi maris appendiculum*

This elegant species of Galathea was discovered by Montagu on the Southern coast of Devon, where it occurs in very great abundance. Young specimens generally lave a white line running down their back, and in this state they are frequently taken by the dredge in deep water.

It may be found under stones at low tide on all the rocky shores of Southern Devon from Plymouth to Torbay.

* Observarit J. Sowerby, juaior. 


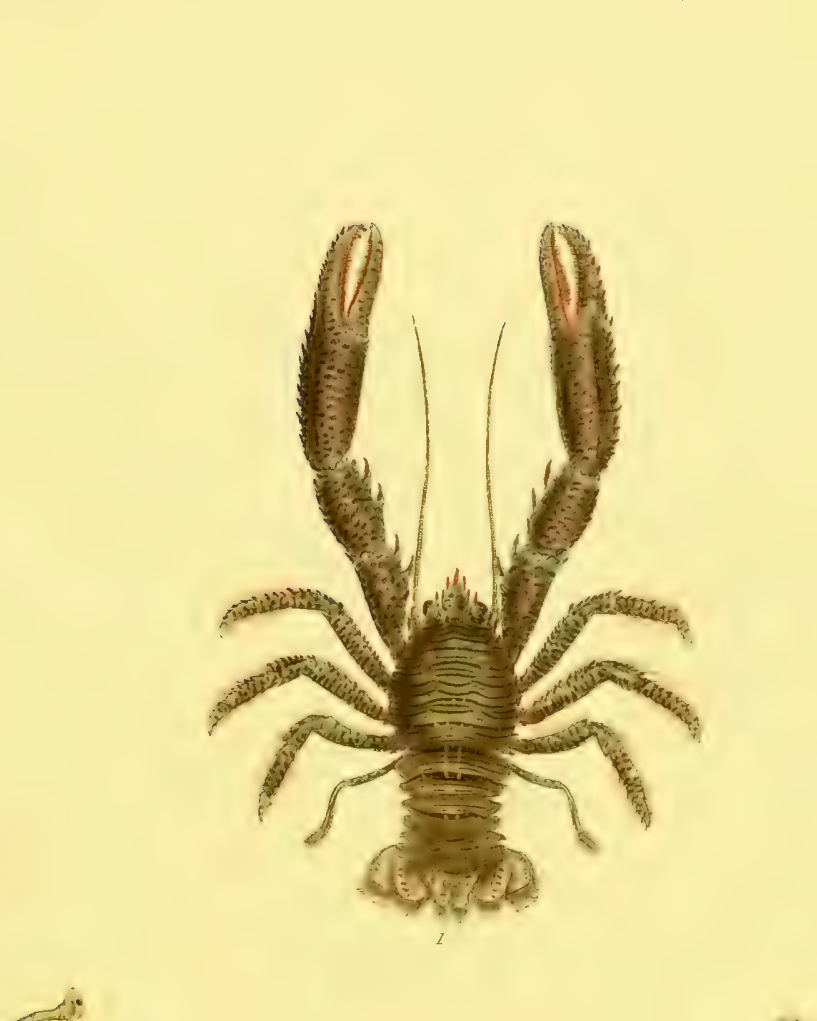






\section{GALATHEA SPINIGERA.}

\section{TAB。 XXVIII. B.}

G. (* b) Pedibus anticis subgranulato-squamosis supra et utrinque spinosis, brachiis externe inermibus,

Astacus strigosus*. Penn. Brit, zool. IV. 18, pl. 14.

Herbst tab. 26. fig. 2.

Galathea strigosa. Fabr. Ent. Syst. 2. 471. Supl.p. 414 .

Latr. Gen. Crust. et Ins. 1. 49.

Leach Edin. Encycl. 7. 398.

Fig. 1, Mas. 2, Ejusdem pullus.

Galathea strigosa is a common species on most of the rocky shores of Great Britain. It has been confounded by all the authors who have noticed it, with Cancer strigosus of Limine, but as it will not agree with the description given in the twelfth edition of the Systema Natura and in the Fauna Suecica, I have been under the necessity of changing the specific mane.

Our figure is colored from a drawing most kindly sent to me by Mirs. Dorville, who drew it from a living specimen.

In the young state the lem; are most elegantly annulated with red and white, as exhibiied in figure 2 .

* Alia et distinctu species est Cancer strigosus Linncei ut heec indicant verba. "Thorax obovatus margine utrinque spinis octo acuminatis antrorsum porrectis ciliatis, dorso rugis numerosis antrorsum imbricatis. Chelæ oblongæ, depressæ, margine aculeatx, supra scabræ, subtus quasi squamosæ; pedes apice rubri." Fn. Sv. ed. all. 2036. "Bractia introrsum aculeata; chelæ oblongx, margine aculeatx, latere superiore antrorsum imbricatæ scabritie ciliari." Syst. nat. XII. 1053. 
. Tnk:xтाII, в
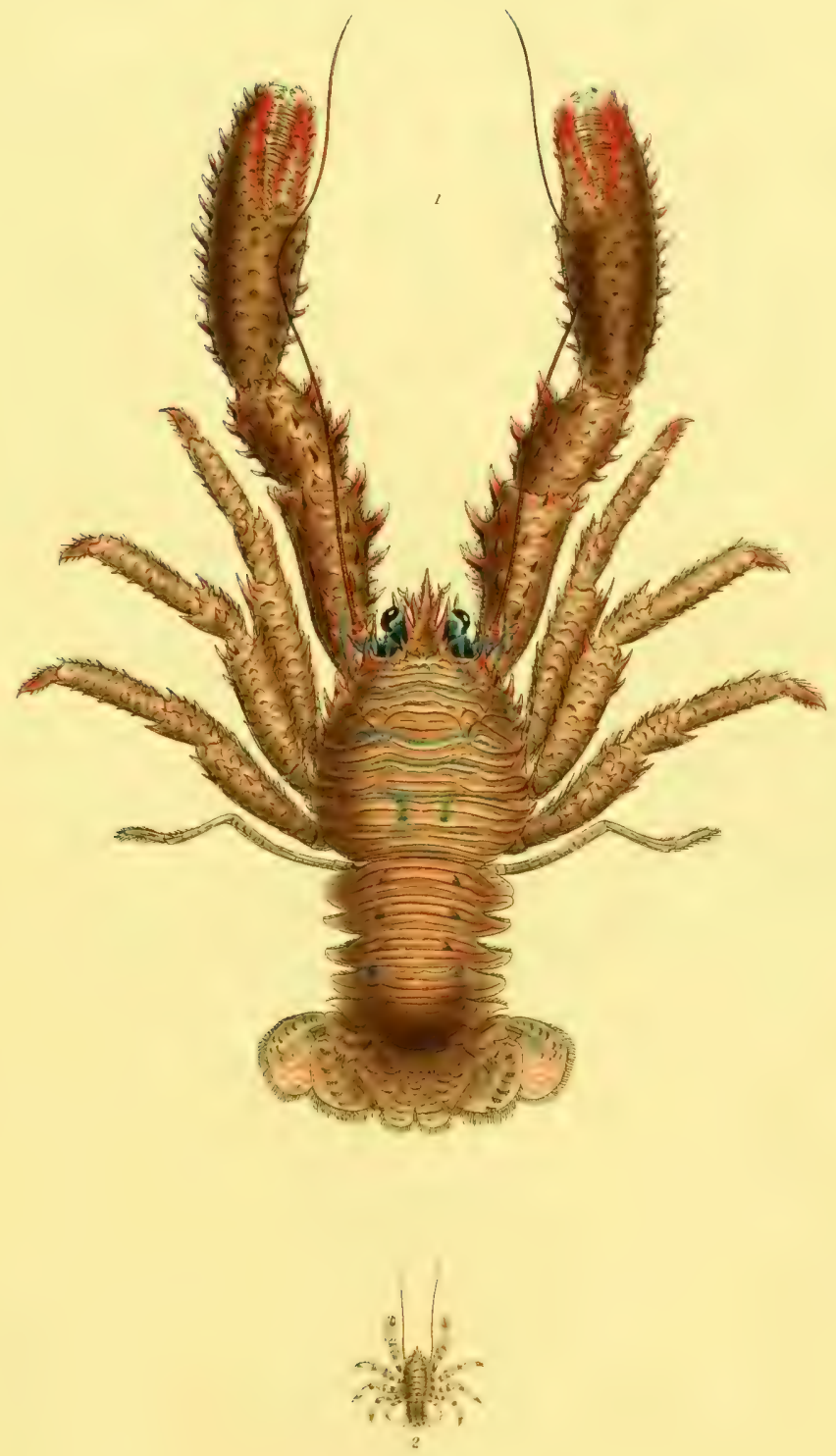




\section{GALATEA RUGOSA.}

\section{TAB. XXIX.}

G. pedibus anticis introrsum præsertim spinosis; abdomine segmento secundo antice 6 , tertio 4 -spinosis.

Astacus Bamffius. Penn. Brit. Zvol. IV. pl. 13.

Cancer rugosus, Gmel. Syst. Nat. 2985. 149.

Galatea rugosa. Fabr. Ent. Syst. 2. 472, Supl. 415. 2.

Bosc Hist. nat. des Crust. 2. 87.

Latr. Hist. Nat. des Crust. et des Insect. 6. 198.

Galatea Longipeda. Lam. Syst. des Anim. sans Virt. 158.

Galatea Bamffia. Leach Edin. Encycl. 7. 398.

Fig. 1, mas. 2, autenna interna. 3, maris senioris manus, digitos curvatos exhibens.

Rondeletius seems to have been the earliest writer to whom this curious Galatea was known, and he has given an intelligible figure in his work "de piscibus," page 542.

Pennant next described it in his British Zoology, from a specimen taken near Bamff in Scotland, and communicated to him by the Rev. Mr. Cordiner.

It appears to be a very rare species in Bitain, as it occurs in but very few collections. In the winter of 1814 my friend Mr. C. Prideaux of Kingsbridge, obtained a fine male and female from the Trawl-fishers, who found them in the Plymouth Sound. These specimens were communicated to me for this work, ard the male is represented in the plate, tegether with one of the internal antennæ and a claw, showing the change that takes place in the form of this part in old specimens.

Herbst has copied Pennant's plate into table 27, fig. 3. of his work. 


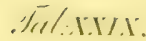

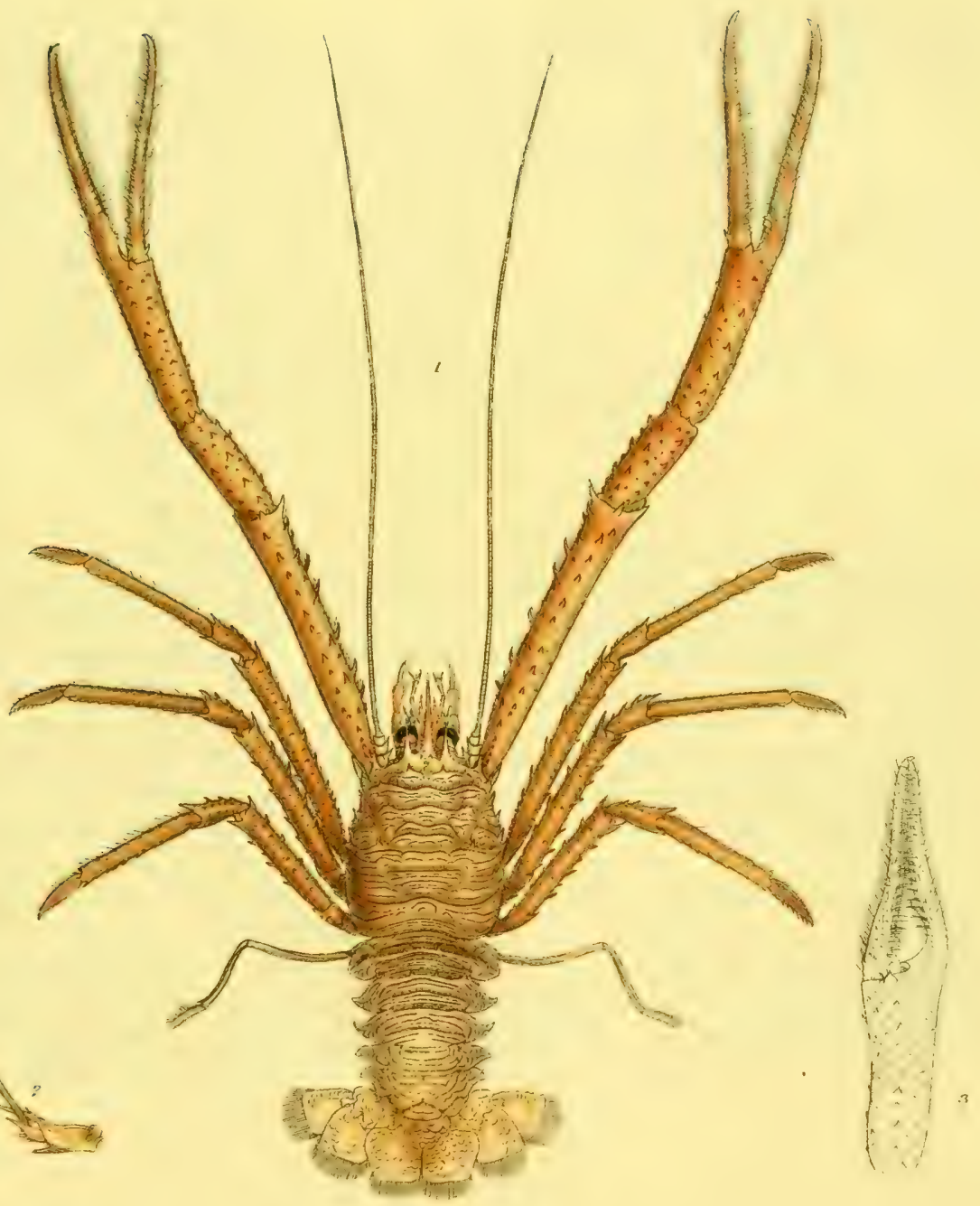





\section{PALINURUS.}

\section{PALINURES, Daldorf, Fabricii, Lamarck, Lalrcille, Bosc, Leach.}

Anfmac infriors brevores, setis duabus articulatis; exteriore breviore, compressâ inferné dilatarâ. pedun:culus longinsimus 3-articulatus; articulis, primo longiore, secundobreviore:

Extrimes setacea longiosims, ariculis tribus basilaribus crassissimis, spinosis; articulis aliis brevissimis fasiculato-pilosis.

Palpi podiformes articulis sex exsertis, ultimo acuminato, subobtuso, hispido.

Oculi pedunculo communi transverso.

Puls decen; par anticum crassius, sublidactylum indice abbreviato; pollice internè fasciculatopiloso; paria secundum, tertium, quartum et quintum simplicia, nuda; ungues fasciculatopilosi, apice curvati nudi.

Abdomen 6-articulatum, segmentis lateribus spinoso-productis.

Coulu pentaphylla; lamellis membranaceis processu medio elongato-subcuadrato apice rotundato. basi crustaceo; processibus aliis squama crustacea ad basin externè.

Interior antenne shortest, with two articulated setr; the exterior seta compressed and dilated bencath; peduncle very long, triarticulated, the first joint longest, the second shortest; exterior antema setaceous, very long, the three first joints very thick, spiny; the other joints very short, with fasciculi of hairs. Feet-like Palpi with six exserted joints; the last acuminate suib-obtuse, hairy. Eyes with a common transverse peduncle. Legs ten; anterior pair thickest, subdidactile, the finger abbreviated, the thumb interially with tufts of hair. Other legs simple, naked; class with tufts of hair, their points naked and bent. Abdomen six-jointed, the sides of the segments produced into spines. Tail composed of five mentranous lamella, the middle of which is elongate-subquadrate, with its base crustaceous; the others with a crustaccous scale at their base externally.

Aristotle. Athenaus, and Pliny were acyuainted with the animals of this grenus, which they named rapafies and Locusta, and used them as food.

The Palinuri live on fith and on other marive animals; they have the power of producing a very loud noise by rubbing the first joint of their exterior anteme against the projecting clypeus.

All the species have a large spine over each eye, and from this part some of the subsidiary specific characters may be drawn. 


\section{PALINURUS VULGARIS.}

\section{TAB. XXX.}

P. spinis superocularibus subtus dentatis; segmentis abdominis sulco transverso, medio interrupto, maculaque utrinque albido.

Astacus Homarus. Penn. Brit. Zool, iv. 16. pl. xi. fig. 22.

Palinurus vulgaris, Latr. Gen. Crust. et Insect. 1. 48.

Leach Edinb. Encycl. vii. 397.

Palinurus Homarus, Leach Edinb. Encycl. vii. 397.

$$
\text { Trans. Lim. Soc, xi. } 339 .
$$

Fig. sup. Palinurus vulgaris magnit, natural. Fig. infor. Palpus pediformis.

Palinurus vulgaris is very common on the western coasts of Englaud, and is sold in the London markicts under the name of thorny lobster and cray-fish. It often grows to the length of eighteen or twenty inches, and is very rarcly found of the small size given in the annexed plate.

Pennant and Latreille are the only authors to whom I can refer for this species. Linné, in the description of his Cancer Ilomarus, has given a generic character, and he refers to figures of at least two species; the one inlabiting the Asiatic, the other the American Seas.

This species is very variable in its colors; all the specimens that I lave scen, however, had a whitish or cream-colored spot on cach side of the back of the abdoncm. In our figure tho most common variety of color is giren, and the whole has been executed with the greatest care and attention, that no doubt may hereafter arise as to the exact species intended. 


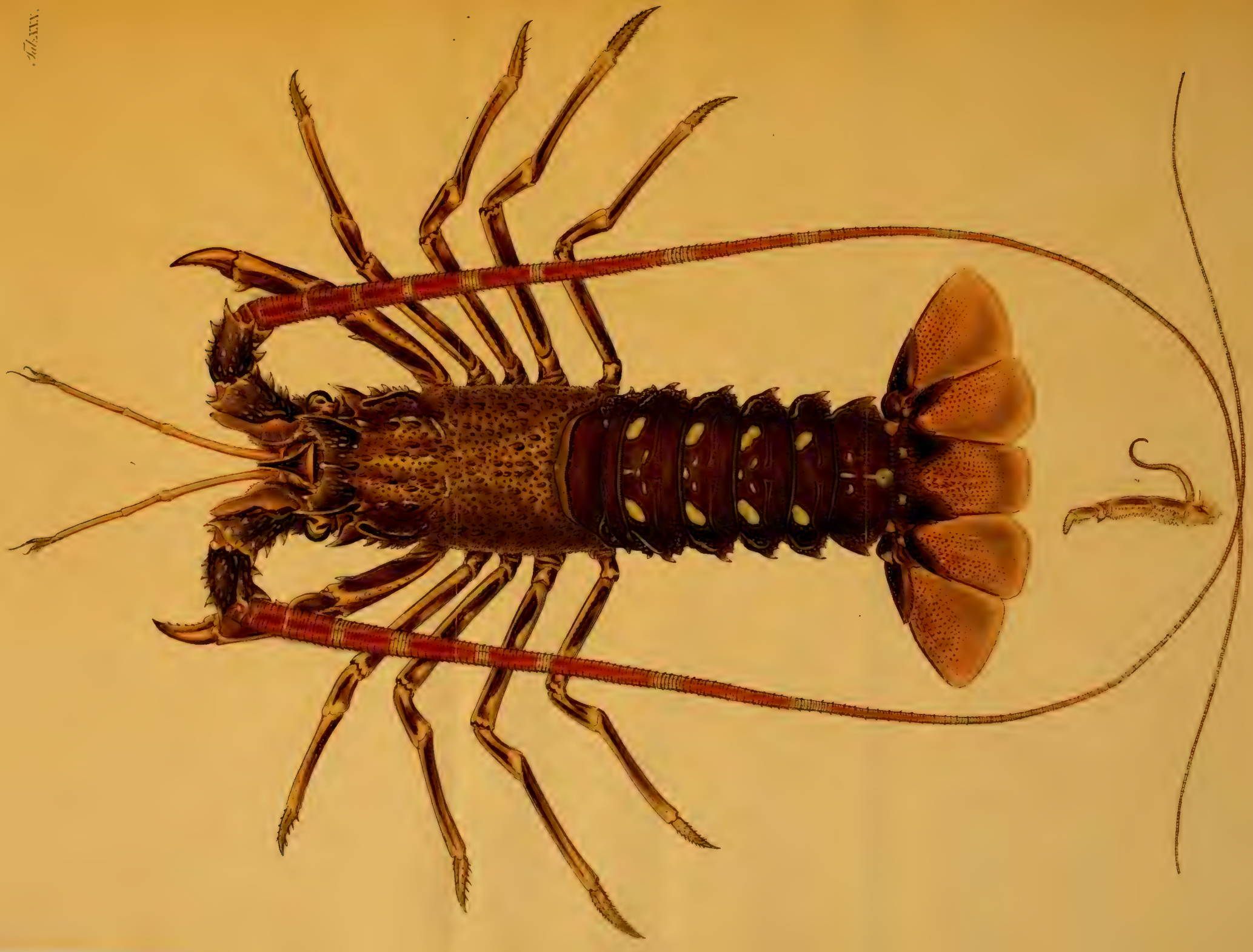





\section{GEBIA.}

\section{CANCER (Astacus), Montagu.}

\section{GEBIA. Leach.}

Antennx in eâdem ferè lineâ horizontali inserix :

intcriores biarticulatæ; articulo primo secundo breviore: pedunculus elongatus basi externè dilatatus: setæ duæ; superiore compressâ.

cxteriores triarticulata; articulo secundo longiore: seta longissima; articulis subelongatis.

Palpi pediformes 5-articulati infra pilosi.

Pedes decem : par anticum majus aquale didactylum ; index abbreviatus : paria alia compressa

pilosa ; ugues simplices.

Abdomen 6-articulatum; articulis transversis.

Cauda pentaphylla; processus lamelliformes lati; lateralibus costatis.

Antennæ inserted nearly in the same horizontal line : inner ones two-jointed; the first joint shorter than the second; the peduncles elongate, their base externally dilated: setre two, the upper one compressed. External antenna three-jointed, the second joint longest; the seta very long, composed of subelongate joints. Pedipalpes five-jointed, hairy beneath. Legs ten; anterior pair largest, equal, didactyle, with the finger short: other pairs compressed, hairy; claws simple. Abdomen composed of seven transverse joints. Tail with five broad lamella; the lateral ones ribbed.

All the species as indicated by the generic name, live beneath the earth, and are only to be obtained by digging in the mud at very low tides.

Gebia is probably confined to the European Seas; it has been confounded with the Indian Genus Thalassina of Latreille, from which it differs in every character. 


\section{GEBIA STELLATA.}

\section{$\mathbf{T}_{\mathrm{AB}}, \mathbf{X X X I}$---Fig。1---9.}

G. abdomine toto crustaceo, caudâ lamellâ exteriore rotundatâ, interiore subacuminatâ, manibus anticis lineis granulatis pilosis.

Cancer astacus stellatus. Mont. Trans. Linn. Soc, ix. 89, tab. iii. f. 5.

Gebia stellata. Leach Edinb. Encycl. vii. 400.

Trans. Linn. Soc. xi. 342.1.

Fig. 1. Gebia stellata mag. nat. 2. Antenna interior. 3. Antenna exterior. 4. Pedipalpus. 5. Pes anticus. 6. Pes secundus. 7. Pes tertius. 8. Cauda.

Gebia stellata was discovered by Mr. Gibbs in the Kingsbridge Estuary; it has likewise been taken on some of the shores of the Plymouth Sound, under the mud in which it makes winding horizontal passages, often of an hundred feet or more in length.

\section{GEBIA DELTURA.}

$$
\text { Fig. 9---10. }
$$

G. abdomine dorso submembranaceo, caudâ lamellâ exteriore apice subrotundatâ dilatatâ : interiore truncatâ deltöideâ, manibus anticis lineis pilosis.

Gebia deltaura. Leach Trans. Linn. Soc. xi. 342. 2.

Fig. 9. Gebia deltura mag. nat. 10. Cauda.

This species lives with Gebia stellata, with which it was confounded, until the distinctions were discovered by Mr. J. D. C. Sowerby. 



\section{CALLIANASSA.}

CANCER (Astacus). Montagu.

CALLIANASSA. Leach.

Antennce in câdem ferè lineâ horizontali insertæ :

interiores pedunculo elongato biarticulato; articulo secundo longiore: seta duas: superiore sub-compressâ.

exteriores pedunculo elongato; seta longissima.

Palpi pediformes articulo secundo compresso longiore.

Pedcs decem: par anticum valdè inæquale didactylum compressissimum: par secundum prims, minus didactylum: par tertium monodactylum : par quartum simplex : par quintum subdidactylum.

Abdomen submembranaceum.

Cauda pentaphylla: processus lati; laterales exteriores interioribus majores costati.

Antenna inserted nearly in the same horizontal line: interior ones with the peduncle two. jointed ; the second joint longest: seta two, the upper ones slightly compresied: exterior ones with an elongate peduncle and seta. Pedipalpes with the second joint longest, compressed. Legs ten : anterior pair very unequal, didactyle, very much compressed: second pair didactyle, smaller than the anterior pair: third pair monodactyle : fourth pair simple : fifth pair subdidac. tyle. Abdomen somewhat membranaceous. Tail with five broad plates; the exterior ones ribbed, larger than the interior lateral ones.

One species only of this singular Genus has hitherto been observed. It has the same economy as Gebia, at least it resides in subterraneous passages of the same construction. 


\section{CALLIANASSA SUBTERRANEA. \\ TAB. XXXII.}

C. thorace anticè abruptè subacuminato, processus rostriformi unicarinato apice rotundato. Cancer astacus subterraneus. Mont. Trans, Linn. Soc. ix. 89. tab. iii. fig. 1-2.

Callianassa subterranea. Leach Edinb: Encycl. vii. 400.

- Trans. Linn. Soc. xi. 343. i.

Fig. 1. Callianassa subterranca mag. nat. \&. Antenna interior. 3. Antenna exterior. 4. Pedipalpus. 5 et 6 . Pedum par anticum mag. nat. 7. Pes secundi paris. 8. Pes tertius. 9. Pes quartus. 10. Pes quinti paris.

The figure in the annexed plate is coloured from a drawing, done from the living animal, by Mrs. Dorville.

C. sublerranea was discovered by Montagu on the Southern coast of Devon, where it is not very uncommon. The larger fore leg is sometimes on the left, sometimes on the right side.

Montagu has described a curious parasite, which is found under the sides of the thorax.See Trans. Linn. Soc. ix. 103. 

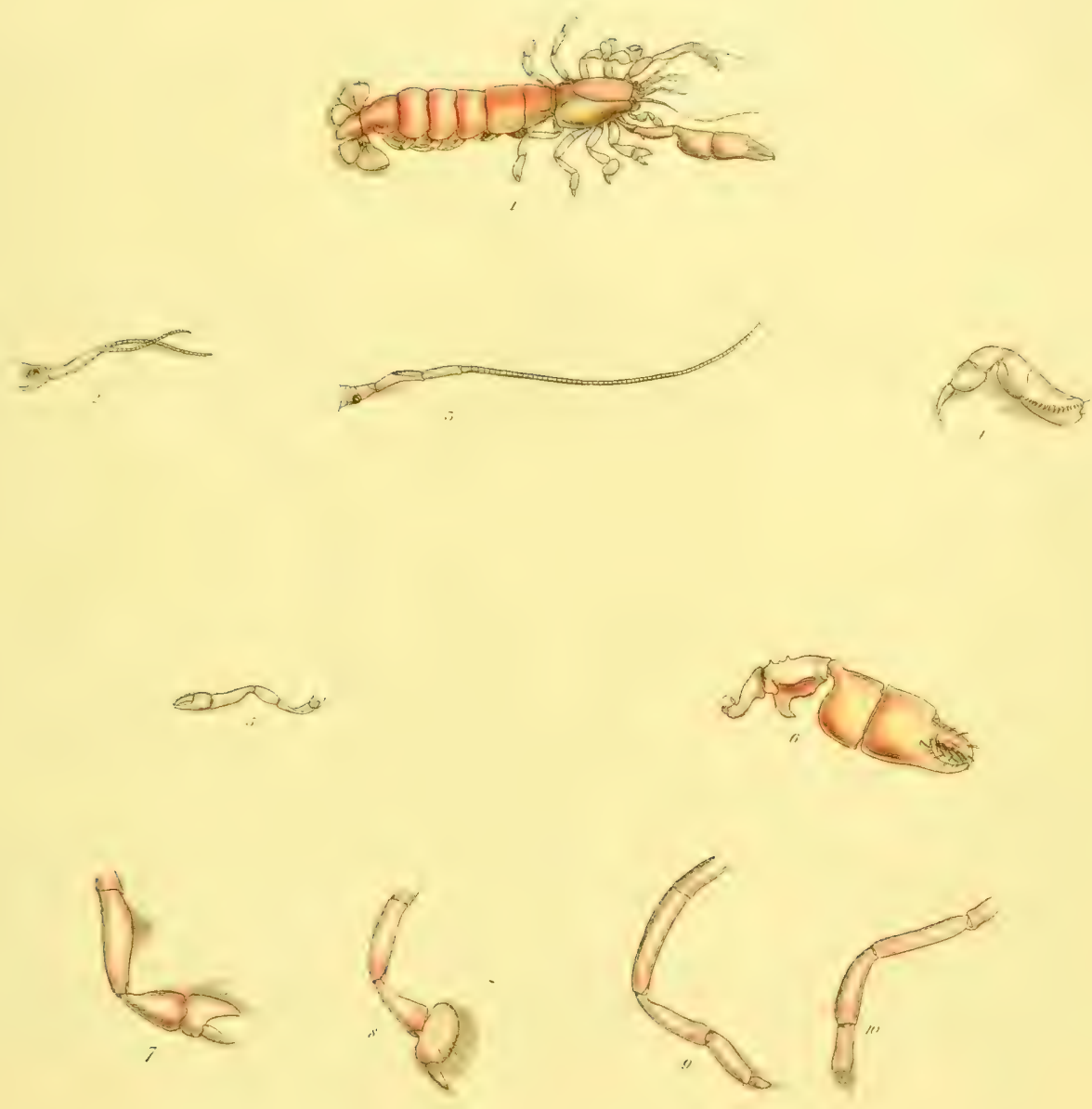
. 



\section{AXIUS.}

AXIUS. Leach.

Antenne in eâdem ferè lineâ horizontali insertæ :

exteriores setaceæ corporis ferè longitudine;

interiores setis duabus.

Pedipalpi gemini externi articulis duabus primis sublongioribus, æqualibus.

Pedes decem : par anticum majus didactylum valdè inæquale: par secundum compressum didactylum: paria alia compressa simplicia; par quintum minus compressum gracilius.

Abdomen 6-articulatum.

Cauda pentaphylla lata: lamella intermedia elongato-triangularis; lamellis exterioribus medio costatis.

Antennæ inserted nearly in the same horizontal line: exterior ones setaceous, and nearly as long as the body: interior ones with two seter. External double pedipalpes, with the two first joints somewhat longer than the others, and of nearly an equal length. Legs ten: anterior pair largest, didactyle and very unequal: second pair compressed, didactyle: other pairs compressed and simple: fifth pair less compressed and more slender than the others. Abdomen six-jointed. Tail with five broad plates: the intermediate plate elongate-triangular: exterior plates with their middles costated.

\section{AXIUS STIRYNCHUS.}

\section{TAB. XXXIII.}

A. rostro marginato medio carinato, thorace pone rostrum lineis duabus elevatis abbreviatis posticè emarginato; emarginatione basi prominente.

Axius stirynchus. Leach Trans. Linn. Soc. xi. 343.

Fig. 1. A. Stirynchus mag. nat. 2. Antenna interior. 3. Antenna exterior. 4. Pedipalpus. 5. Pes anticus. 6. Pes secundus. 7. Pes tertius. 8. Pes quartus. 9. Pes quintus.

Axius Stirynchus was first obtained by myself at Sidmouth, where it was taken amongst prawns on the shore. Montagu afterwards procured near Plymouth another specimen, which forms part of his collection of British Zoology, lately purchased by the trustees of the British Museum. 

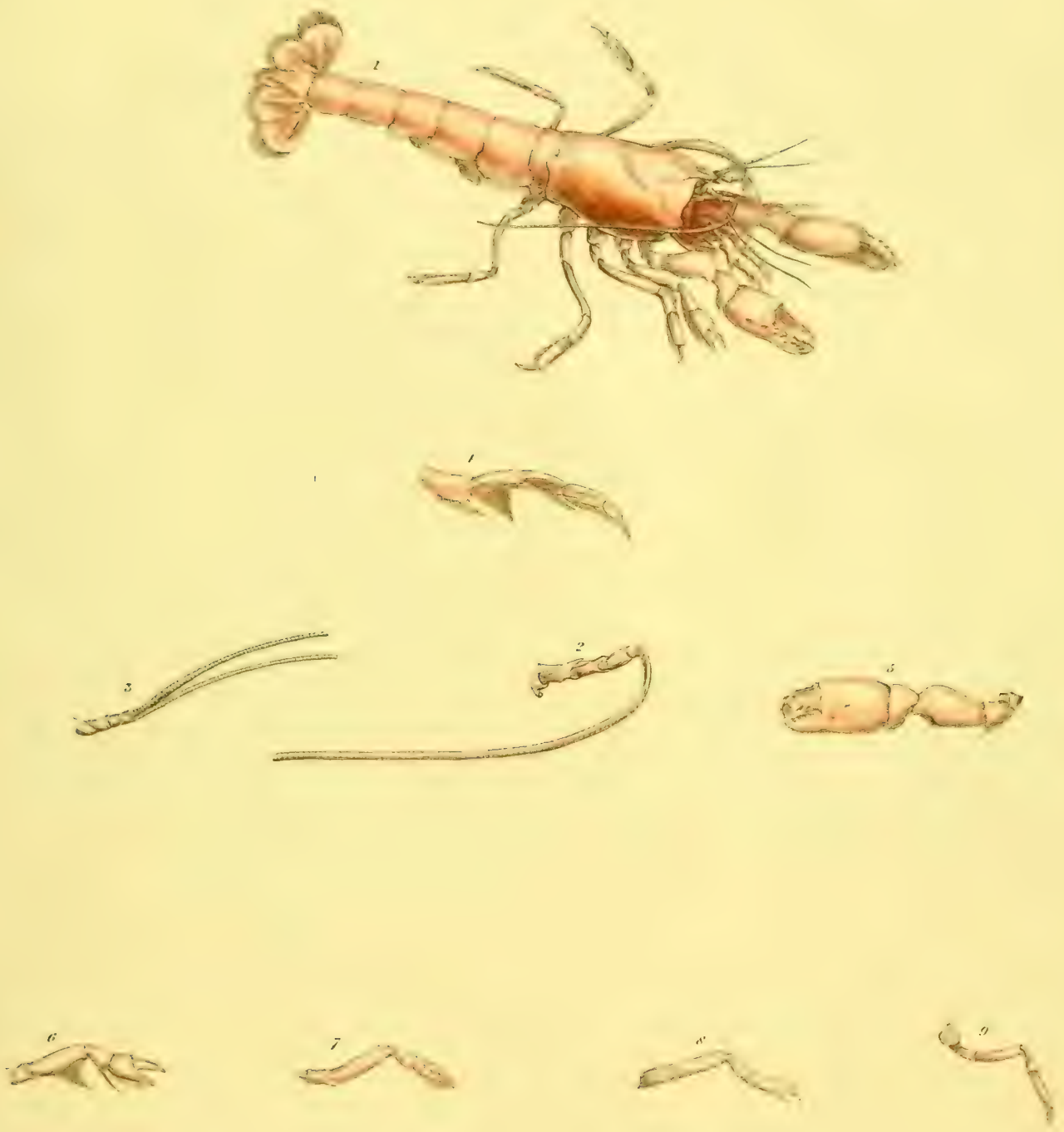



\section{POTAMOBIUS.}

\section{CANCER, Linncus.}

ASTACUS, Fabricius.

\section{POTAMOBIUS, Leach.}

Antenne cxtcrnce elongatie, subtus et extus internas insertre, pedunculo crasso, articulis secundo et tertio subcylindricis, squama mobili tectis.

Antenne internce setis duabus ciliatis.

Pedipalpi externi articulo secundo latissimo, crasso.

Pedum par primum fere aquale, tumidum, carpo brevi, rotundo, manu leviter tuberculatum; paria secundum et tertium attenuata, didactyla; paria quartum et quintum monodactyla.

Testa medio sulco transverso profundo subdivisa; rostrum breve, trigonum utrinque unidentatum.

Abdomen quinque-articulatum, læve.

Cauda pentaphyla, segmento primo-mediani utrinque unidentato.

External antennæe long; inserted below and outside the internal, with thick peduncle, second and third joints eylindrical, corered by a moveable scale. Internal antennז with two ciliated filaments. External pedipalps with second joint very broad and thick. Carapace divided in the middle by a deep transverse groove. Rostrum short, trigonal, single-toothed at each side. First pair of feet nearly equal, large, thick; wrist short, rounded; hand slightly tuberculated; second and third pairs attenuated, two-fingered; fourth and fifth pairs single-fingered. Abdomen with five joints, smooth. Tail with five flaps; first section of the middle flap with a strong touth on each side.

\section{POTAMOBIUS ASTACUS.}

\section{TAB. XXXIV. Fig. 1.}

P. testa granulata, rostro pedunculum antennarum longitudine aquanti, medio carinato, utriurque dente parvo versus extremitatem armato.

Cancer astacus. Linneus. 
Astacus fluviatilis. Fabricius, Ent. Syst. Suppl. p. 406.

Latreille, Gen. Crust. V. p. 235.

Potamobius fluviatilis. Leach, non Risso.

Fig. 1. Potamobius astacus.

There has been some confusion of synonrms between this species and the common lobster. The present editor, howerer, belieres that the nomenclature adopted by the authorities in the British IIuseum is the more correct. In general appenrance the Potamobius is a miniature representation of the marine Lobster, and is abundantly diffused through all the larger rivers of our country, as well as those of Europe generally. It is much in request for the table, under the name of the "River Cray-fish." Specimens will live for some time in a fish-tank, where their liabits, which are very interesting, may be observed. One in possession of the writer, shed his onter corering so neatly, and with so little disturbance of the parts, that it was at first thought there were two Cray-fish instead of one in the tank. Although of a dull greenish colour when living, the shells turn red, when boiled, like the common Lobster. 
Tab.XXXTV
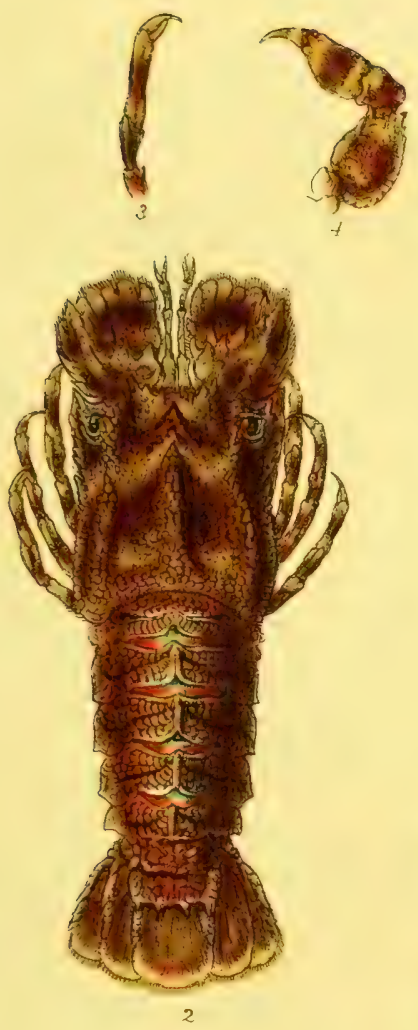

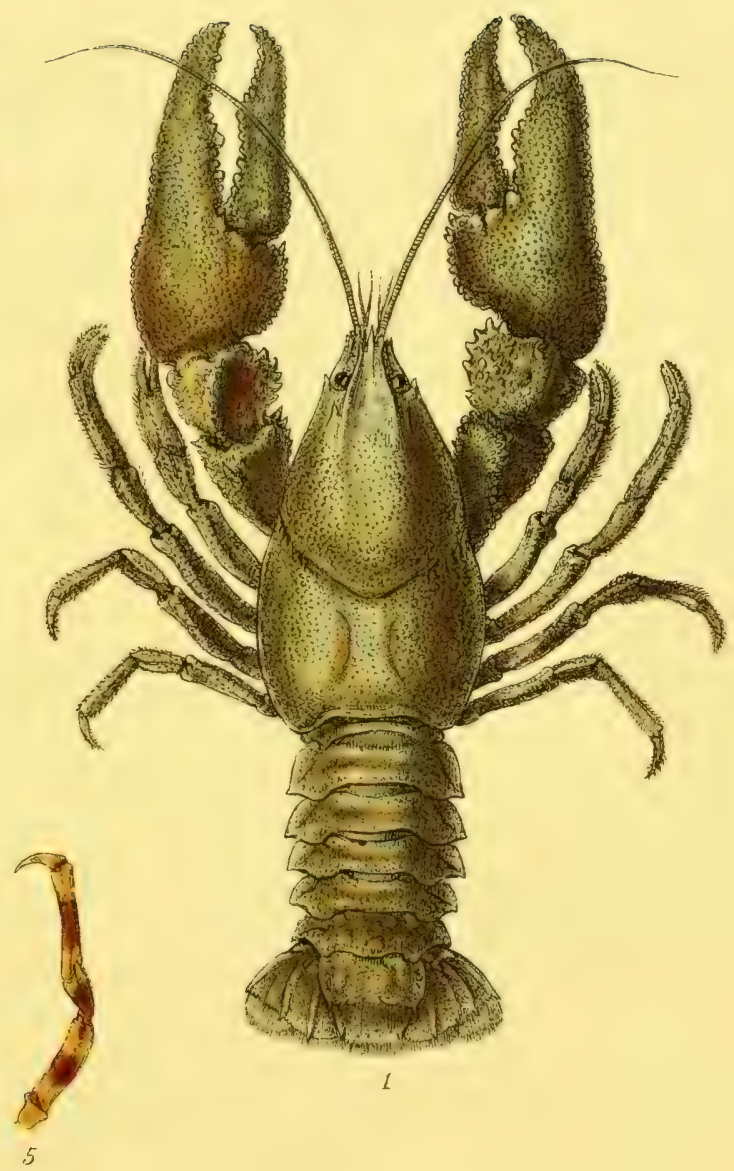





\section{SCYLLARUS.}

SCYLLARUS, Fabricius,

CANCER, Linnaus, Herbst.

Antenne cxterne latissime, thabelliformes, pedunculo articulis dilatitis, cristatis.

Antenne interner quatuor, dissimilima, medianis fililormitus; articulo ultimo bifido.

Oculi distantissimi.

Testa lata, oblongo-subquadrata.

Pedum par primum breve, articulis inflatis, manu monodactyli ; paria 2,3,4, ferè consimilia ; par ultimum didactyle.

Abdomen sex-articulatum, segmentis ad latera spinoso-productis.

Cauda pentaphylla, in lamellis membranaceis terminans, medio transrersi articulata, margine articuli primi acutissime dentato.

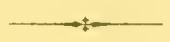

\section{SCYLLARUS ARCTUS.}

\section{TAB. XXXIV. FIG. 2, 3, 4, 5.}

S. testa squamoso-tulerculata, nnticè acutissime quadridentata, frontis margine concavo, cristato, marginibus lateralibus bidentatis, antennis externis flabelliformibus, acutè dentatis, antice lobatis, ciliatis.

Scyllarus arctus. Fabricius, Ent. Syst. Supp. p. 309, I.

Cancer arctus. Linnceus, Syst. Nat.

Cancer (Astacus) Ursa Major. Herbst, II. p. 83, t. 30, f. 2.

Fig. 2, Scyllaris arctus. 3, fifth claw. 4, first claw. 5, middle claw.

The name of this curious crustacean was first added to our list of British faum by ly Borlase, who found specimens in Mount's Bay, Cornwall. They have also been not unfreenuently taken on other parts of our consts. The more usual order in decapodous crustacen is reversed in this case, the first pair of lengs being sing he-clawed, and the last fronlily double-clamed. 




\section{ASTTACUS.}

ASTACUS, pl. Fabricius, Leach.

\section{CANCER, Linnæus.}

\section{HOMARUS, M. Edwards. (postea.)}

Antennce interioies breves, bifidi; cxteriores longissimæ, pedunculo fere cylindrico, appendice laminari dentiformi, intùs dilatata, vix articulum ultimum pedunculi obtectenti.

Palpi peliformes ante pedunculos antemnarum extensi, articulis sex exsertis, ultimo acuminato, hispido.

Pedes decem: par anticum crassissimum inæquale, digitis validè tuberculatis; paria secundum et tertium didactyli, quartum et quintum monodactyli ; ungues fasciculato-pilosi, curvati, obtusi. Abdomen sex-articulatum, segmentis ad latera in laminis latis complanatis terminantibus.

Cauda pentaphylla laminis exteriorilus versus terminum articulato-divisis, ad articulum acutè dentatis.

External antenne above and outside the internal. The laminar appendage tooth-shaped, dilated on the inner side and not quite covering the penultimate joint of the peduncle. The exterior pedipalpus pediform and produced forwards beyond the peduncles of the antenur. The five pairs of legss are very lirrge, thick, and unequal; the grasping edges of the thumb and finger in the larger tuberculated; in the smaller toothed; second and third pairs narrow, with two fingers on the last joint; fourth and fifth with the last joint undivider. The carapace nearly cylindrical, the rostrum curved forwards and having several tecth on each side. The six segments of the abdomen terminate at each side with a broad flat flap; last segment with a sharp tooth at each side ; outer laminæ of the tail divided transrersely at about one-third distance from the end, in a moveable joint, the edge of the larger portion being sharply toothed.

This genus, the principal member of which is our common Lobster, was included under the specific name of gammarus in the Linnean genus Cancer. It is associated by Lamarch with the little-fresh water Lobster in the genus Astacus, our large edible crustacean being named A. marinus and our smaller one A. fluviatilis. 



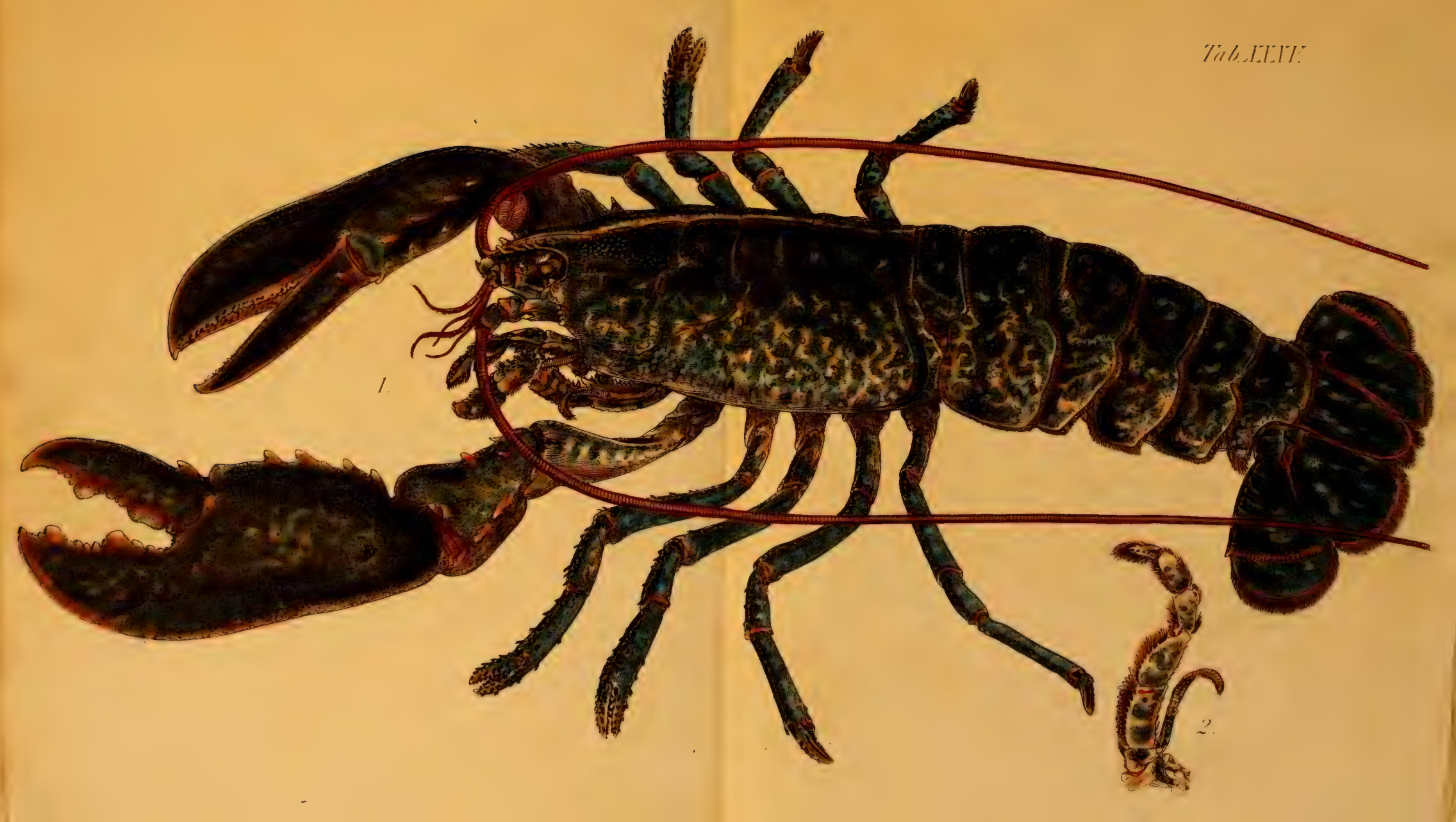





\section{ASTACUS GAMMARUS.}

\section{TAB. XXXV.}

\section{CANCER gammarus, Leach.}

1. carapace cylindrico, leviter puncturato, prope medium sulco diviso; pedunculo antennarum majorum basi unidentato; oculis globosis quam pedunculos minoribus; segmentibus abdominis levibus, ad latera planilobutis ; cauda latissima, laminis exterioribus dentato-articulatis.

Cancer gammarus, Linnaus. Syst. Nat.

Astacus marinus, Fabricius. Suppl. p. 406. Pennant, Brit. Zool. IV. t. X. f. 22.

Homarus vulgaris, Mlilne Edwards. Hist. Crust. II. p. 324.

The supply of this inestimalle crustacean annually brought to the London markets for our tables from the Channel Islands, from various localities on our own coasts, and above all, from those of Torway, has been something wonderful. The latter have supplied above 600,000 annually, and the former combined about 200,000 .

Like Crabs and Cray-fish, the Homarus vulgarus, or common Lobster, is known, when caught by a claw; to escape by shaking oft the limb, learing it in the hands of the captor. And it is believed that sudden fright produced by the noise of cannon or thunder will sometimes cause the creature thus to dismember itself.

The colour of the species is dull reddish yellow spotted with blneish black, the under side appearing beantifully marbled. The specimens vary very much according to the localities in which they occur. In each of their special haunts the range of the Lobster is limited, and each little community of them retains its omn characteristics. These are in many cases so marked that good authorities have declared that on seeing a specimen they could indicate the spot whence it had been brought. 



\section{NEPHROPS.}

\section{ASTACUS. Pennant.}

\section{NEPHROPS. Leach.}

\section{CANCER. Linné.}

Antennc in eâdem lineâ horizontali insertæ :

Intcriores setis duabus; superiore crassiore compressâ ; inferiore setaceâ, tereti.

Exteriores pedunculo articulo primo squamâ ultra pedunculi apicem prodeunte.

Palpi podiformes articulis quinque exsertis; articulo primo laiere interiore supra dentato, infia subserrulato.

Oculi maximi, reniformes, pedunculo abruptè et multò crassiores.

Pedes decem ; par anticum majus, inæquale, didactylum; manu filiformi : paria 2 et 3 didac.

tyla, filiformia; paria 4 et 5 filiformia, ungue terminata; ungues acuminati.

Abdomen sex-articulatum; segmentis lateribus acutis.

Cauda pentaphylla; processu exteriore bipartito, articulato.

FEMINA coxis tertiis, MAs coxis quintis perforatis.

Antennæ inserted in the same horizontal line: interior ones with two setæ; the upper seta compressed; the under seta setaceous, rounded : exterior antennæ with a scale on the first joint of their peduncle, extending beyond the apex of the peduncle. Pedipalpes with five exserted joints; the first joint with the interior side dentated above, subserrulated beneath. Eyes very large, kidney-shaped, much and abruptly thicker than their peduncle. Legs ten ; anterior pair largest, unequal, didactyle ; second and third pairs filiform, didactyle; fourth and fifth pairs filiform, terminated by acuminate claws. Abdomen six-jointed; the sides of the segments acute. Tail with five plates; the exterior scale articulated.

The form of the eyes, and the sexual perforations, distinguish this genus from. Astacus. 


\section{NEPHROPS NORVEGICUS.}

N. testa dorso subcarinato.

Cancer Norwegicus. Linn. Syst. Nat, 1. 1053.

Astacus Norwegicus. Penn. Brit. Zool. iv. 1\%. t. 12. fig. 24.

Nephrops Norvegicus. Leach Edin. Encycl. vii. 400.

Trans. Linn. Soc. xi. 344.

Le Homar lettré. Ascan. Icon, rer, natur. Tab. xxxix.

Fig. 1, Nephrops Norvegicus. 2, Palpus peditormis.

The colour of the $\mathcal{N}$. Norvegicus is a pale flesh-red, occasionally varied with darker colour or with whitish. The grooves of the fore claws, and back of the abdomen are pale fulvous or cinereous. Eyes blackish.

Sometimes the left anterior leg, and at other times the right is largest ; the internal edge of the fingers of the larger leg being knotted; of the smaller one denticulated.

In the summer months this species is very abundant, in the Frith of Forth, and is taken adhering to the bait of the fishermen who are employed in taking fish with lines.

Fabricius, and all succeeding authors, describe this species as having but four didactyle legs, which renders their synonyms extremely doubtful: I have, therefore, refrained from. quoting them. 



\section{PONTOPHILUS.}

\section{CRANGON. Leach.}

Antemu superiores breviores setis duabus in câdem ferè linê̂ horizontali insertis: set $\hat{\imath}$ interiore longiore.

infcriores coiporis longitudine setacex decrescentes, squamâ ad apicem externé unidentatâ pedunculo annexâ : articulo primo ultra medium squamæ producto.

Palpi pediformes articulis quatuor exsertis articulo ultimo acuminato procedente duplo ferè longiore.

Pedes decem: par anticum majus compressum subdidactylum; pollice brevissimo: par sccundum tenue brevissimum dislactylum: par terlium tenue elongatum ungue simplici instructum : paria 4 et 5 præcedente crassiora unguibus compressis instructa.

Abdomen 6-articulatum.

Cauda pentaphylla: lamellis lateralibus angustis.

Upper antemme shortest, with two seta inserted in nearly the same horizontal line; the interior longest: under antenna as long as the body, setaceous, with a large squama at their base, with a spine in the apex externally; the first joint produced beyond the middle of the squama. Pediform palpes with three exserted joints; the last acuminated, and almost twice the length of the preceding joint. I-gs ten : first pair longest, compressed, subdidactyle, with the thumb very short: second pair slender, very short, didactyle: third pair slender, clongate, furnished with a single claw: fourth and fifth pairs thicker than the third, and furnished with compressed claws. Abdomen six-jointed. Tail composed of five plates; the lateral ones narrow. 


\section{PONTOPHILUS SPINOSUS.}

\section{TAB, XXXVII,---A.}

P. thorace lineis quinque longitudinalibus spinosis; tribus dorsalibus; unâ utrinque laterali. Crangon spinosus. Leach Trans. Linn. Soc. xi. 346.

Fig. 1. Pontophilus spinosus mag. nat. 2. Antenna inferior auct. 3. Antenna superior auct. 4. Pes anticus ampl. 5. Pedipalpus auct. 6. Pes secundus auct. 7. Pes tertius ampl. 8. Pes quartus auct. 9. Pes quintus amplificatus.

This curious animal was discovered by C. Prideaux, Esq. amongst some rubbish dredged in the Sound of Plymouth, near the Edistone; a second specimen was afterwards taken off Falmouth, by the late Mr. John Cranch, Zoologist to the Congo Expedition.

Its natural color is unknown. 


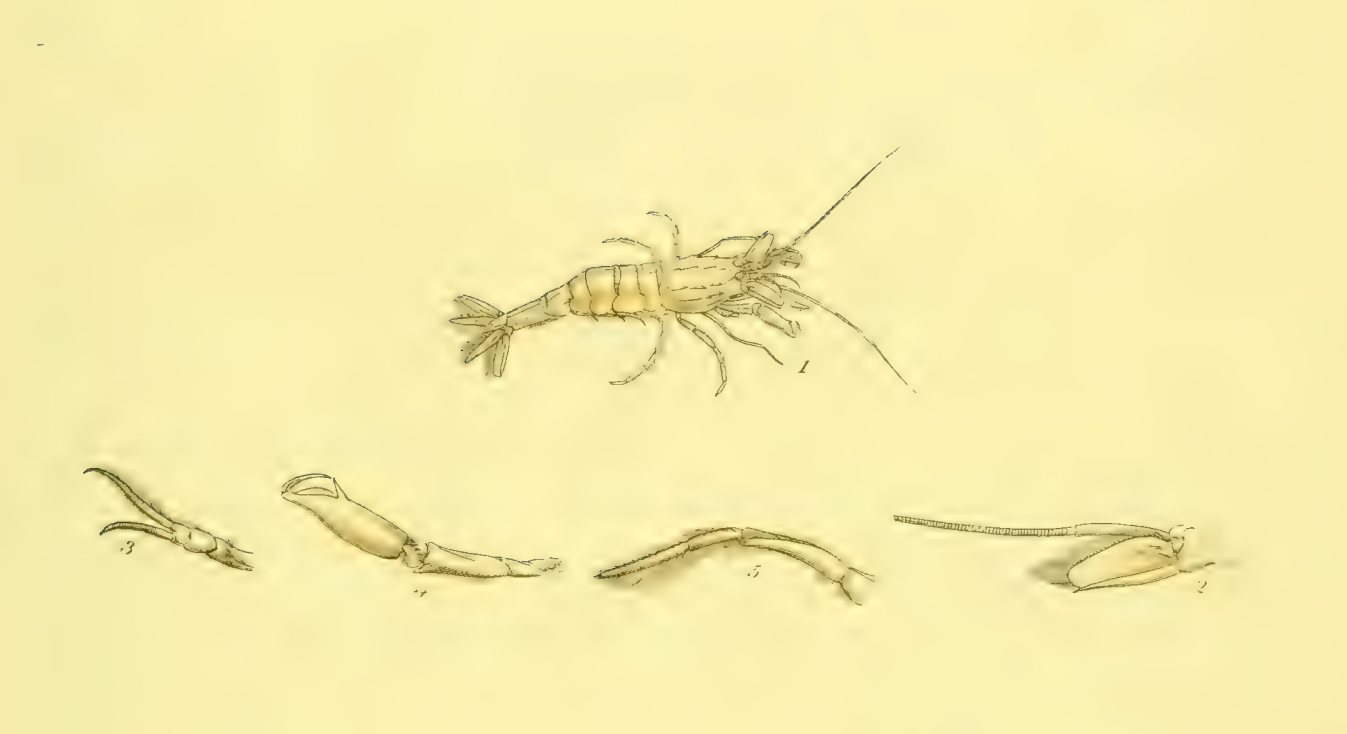





\section{CRANGON.}

\section{CANCER. Linné.}

\section{ASTACUS. Pennant.}

\section{CRANGON. Fabr., Latr., Bosc, Leach.}

- Antennce superiorcs setis duabus in eâdem ferè lineâ horizontali insertis : interiore longiore. inferiores corporis longitudine setacex decrescentes squamâ ad apicem externè unidentatâ pedunculo adnexâ : articulo primo ad squamæ medium non producto.

Palpipediformes articulis quatuor exsertis : duobus ultimis longitudine aqualibus; hôc apice obtuso.

Pedes decem: par anticum majus compressum subdidactylum ; pollice brevissimo : par secundum elongatum tenue didactylum: par tertium tenue præcedente longiore subcrassiore ungue simplici instructum: paria 4 et 5 pracedente crassiora unguibus compressis instructa.

Abdomen 6-articulatum.

Cauda pentaphylla: lamellis lateralibus angustis.

Uper antenna with two seta inserted in nearly the same horizontal line; the inner one longest. Under antennx as long as the body, setaceous, with a large scale, having its apex externally armed with a spine, at their base: first joint not produced to the middle of the squama. Pediform palpes with four exserted joints; the two last equal in length; the latter with the apex obtuse. Legs ten : anterior pair largest, compressed, subdidactyle, with the thumb very short: second pair elongate, slender, didactyle : third pair slender, longer, and rather thicker than second pair, furnished with a single claw : fourth and fifth pairs thicker than the precedirg: with compressed claws. Abdomen six-jointed. Tail composed of five plates; the lateral ones narrow. 


\section{CRANGON VULGARIS.}

\section{TAв, XXXVII, ..- B.}

C. thorace pone rostrum et utrinque brachiisque infra unispinosis.

Cancer Crangon. Linn. Syst. Nat. i. 1052.

Astacus Crangon. Penn. Brit. Zool. iv, 20.

Crangon vulgaris, Fabr. Ent. Syst. Süpl. 410.

Latr. Gen. Crust. et Insect. i. 55.

Bosc Hist. Nat. des Crust. ii. 96.

Leach Edinb. Encyl. vii. 401. Pl. 20)1. fig. 5.

Trans. Linn. Soc. xi. $3 \pm 6$.

Encycl. Britt. Suppl. i. 421.

Fig. 1. Crangon vulgaris mag. nat. 2. Antenna inferior aucta. 3. Antenna superior auct. 4. Pedipalpus auctus. 5. Pes anticus auctus. 6. Pes secundus amplificatus. 7. Pes tertius auct. 8. Pes quartus ampl. 9. Pes quintus auct. 10. Cauda ampl.

Crangon rulgaris, or Common Shrimp, inhabits most of the sandy shores of the British Seas, often entering estuaries, especially during the breeding season: it sometimes ascends rivers with the tide, and is left in great quantities in the saline marshes. 

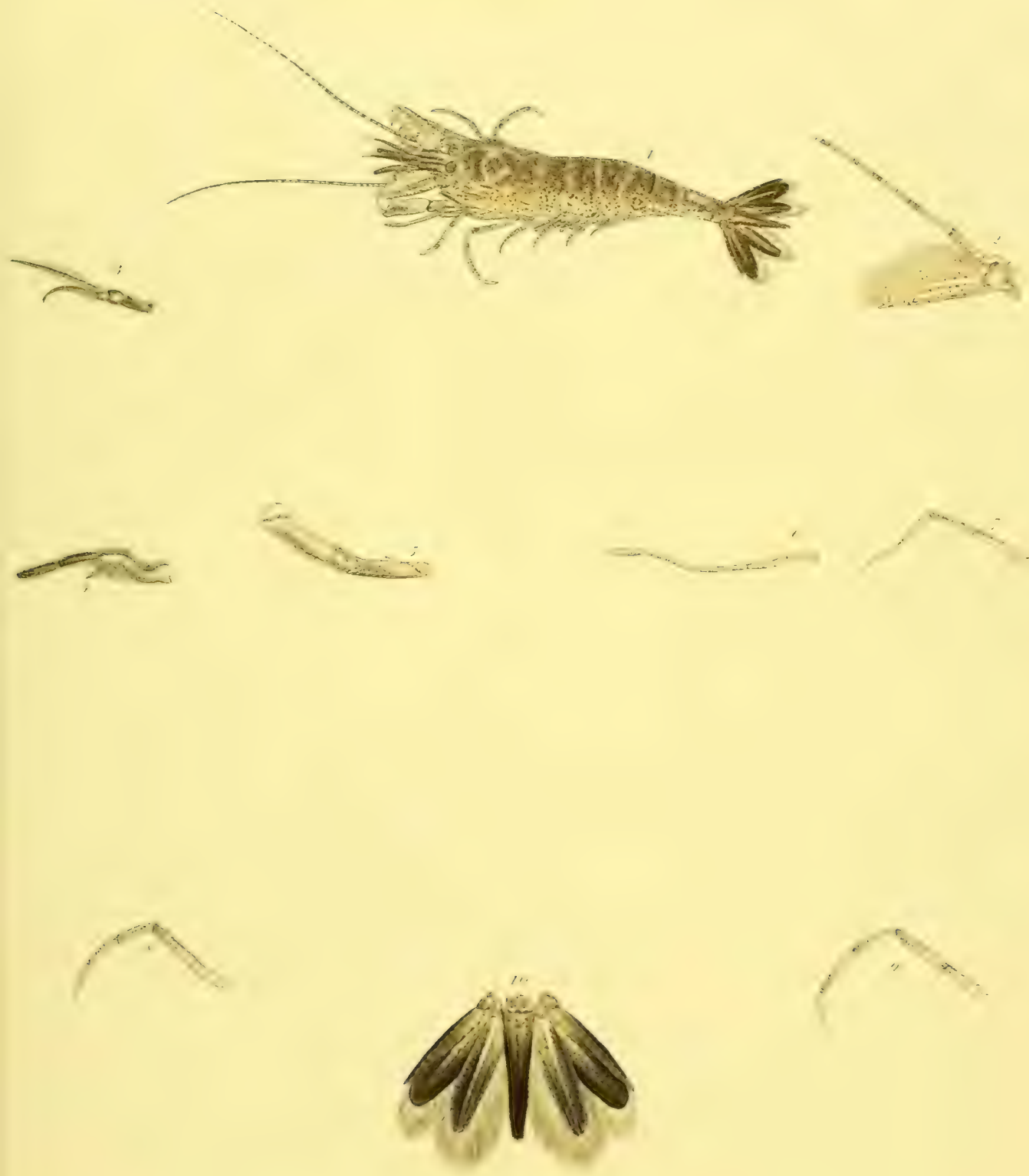


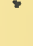




\title{
CRAGNON FASCIATUS.
}

\author{
Tab. XXXVII. c. Fig. 1.
}

('. preinn secundo pari filiforme, quam primum et tertium breviore minute diclactyle; ablomine al articulum quartum subitò contracto, fusco latifasciato. Spinâ sterni obsoletâ. Clagnon fasciatus, Risso, Crust. de Nice, t. III. f. 5, p. 82.

The colour of this shrimp resembles that of the common species, excepting in the dark minkings on the second and third and a brown band across the fourth segment of the abdomen. The fourth sement contracts rather suddenly, and the fifth and sixth are comparatively short anul narrow. The sternal spine, sharp and strong in the common shrimp, is almost obsolete in thispecies. The first specimens found on our const were taken in Salcombe Bay in Devonshire.

\section{ALPHEUS.}

ASTACUS, Fabricius.

\section{ALPHEUS, Fabricius, Leach, Latreille.}

Antenne externce subtus et extus internas locate, palpo lamellari ang usto et acuminato.

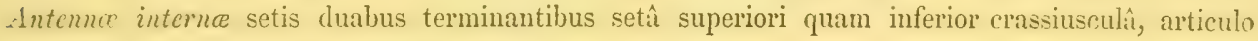
basali brevi, squamâ spinifermi munito.

Pedipalpi externi angusti, elongati.

I'clum prir primum magnum inæquale dirlactyle; par secundum filiforme, didactyle, tenuissimo, carpo multiarticulato; paria altera attenuata, monodactyla.

Testa antice super oculos arcuatim producta.

Abdomen elongatum.

Exteña ANTExxe pliced underneath and outside internal; laminar flap narrow and acuminated. Interual antenne ending in two setr; upper seta rather thicker than under, basal joint short, provided with a spiniform scale. External pedipalps narrow, elongated. First pair of feet large, mnequal, didactyle; second pair filiform, very thin, didactyle, with multiarcutate wrist. Carapace produced in an arch over the eyes. Abdomen elongated. 


\section{ALPHEUS RUBER.}

\section{TAв. XXXVII. c. Fig. 2.}

A. rostro parvo, antennæe externæ spina basali nulla brachiis spinâ minutâ prope extremitatem, ad marginem superiorem manu majori quadricarinato; digito mobili quam alterâ breviori. Alpheus ruber. Ednards, Hist. Crust. 11, p. 251.

Fig. 2. Alpheus ruber.

The first specimens procured in this country were taken from the stomachs of cod-fish near Falmouth. The species was long previously known as inhabiting the Mediterranean Sea. The general form is that of a shrimp, but in the front pair of feet the hands are enormously large and quite dissimilar in form and character, the larger having scarcely any hairs, but strong tubercles on the nippers, and the smaller having those organs lanceolate and hirsute. 


\section{PASIPH无A.}

ALPH EUS, Risso.

PASIPHAA, Savigny, Leach, Risso.

Antennce externce subtus internas locatie.

Antennce internæ pedunculo attenuato, setis filiformibus duabus inæqualibus.

Palpi pediformes elongati ad basim, squama laminata muniti.

Pechum paria primo et secundo didactyla ; paria $3,4,5$ attenuata, monodact lia.

Testa elongata, lateraliter compressa, antice angustata.

Abdomen 6-articulatum, elongatissimum, valde compressum.

Cauda pentaphylla, lamellis lateralibus angustis.

External antennæ placed beneath the internal, which have an attenuated peduncle with two filiform unequal setæ. Pedipalps long, with a laminated scale at the base. First and second pairs of feet didactyle; third, fourth and fifth pairs attenuated and monodactyle. Carapace elongated, laterally compressed, narrow in front. Abdomen 6-jointed, very long; much compressed. Tail five-flapped, side-flaps narrow.

\section{PASIPH瓜A SIVADO.}

\section{FIG. 3.}

P. rostro parvo, acute dentiformi; laminis externis caudæ quam internæ longioribus. Pasiphæa sivado, Risso, Crust. Nice, t. III. f. 4. Latreille, Regne Anim. Cuv. IV. p. 99. Pasiphra Savignyi, Leach. MS. in Brit. Mus.

Fig. 3, Pasiphæa Sivado.

The first British specimen seen by the author (Dr. Leach) was in a collection of British Crustacea formed by Mr. J. Sowerby in his Museum at Lambeth. Others were afterwards obtained from Mr. Baker and Mr. Macandrew, taken in the Irish and Bristol Channels, and placed in Dr. Leach's private collection. The specimen stated to have been in the British Museum under the name of P. Sarignyi in the Doctor's hand-writing, is probably the same as now appears there correctly labelled, P. Sivado. Dr. Leach probably did not notice the description by Risso, or seeing it was uncertain about the identity of the species. 



$$
7^{2}
$$





\section{MYSIS SPINULOSUS.}

Fig. 4-6.

II. lamina centrali caudæ bifurcata; rostro obtuso, longitudine trientem pedunculi oculorum æquante.

II ysis spinulosus, Leach, Trans. Linn. Soc. XI. p. 350, Desmarest, Edrards, de.

Mysis Leachii et Mysis Chamoleon, Thomson, Bell, \&c. (postea, Ed.)

Fig. 4, Mysis spinulosus, Mag. auct. 5, cauda. 6, pes duplicatus quintus.

The present editor believes that Professor Bell, persuaded as he was of the identity of Leach's species with the M. Chamœleon of Thomson, ought to have followed Desmarest, Edwards, \&e. in retaining Leach's name. The reason given for departing from the law of priority in this instance, mamely, that the term "spinulosus" applies to other species of the genus, is quite insufficient. The species has the middle joint of the tail bifurcate.

\section{MYSIS INTEGER.}

FIG. 7, 8 .

II. caudex lamina centrale lanceolata, apice integro ; rostro brevi, long̨itudine trientem pedunculumm oculorum æquanti. Squama antennarum testam longitudine æquanti.

Mysis integer, Leach, -? MLS. Mus. Brit.

MIysis vulgaris, Thomson, Zool. Researches, p. 30, t. 1, Edwarls, \&c.

Fig. 7, Mysis integer. 8, cauda.

Professor Bell haring been able to quote Dr. Lench's description of this species shews it to lave been published somewhere, although we do not know in what work. The specimen in the British Iruseum named in Dr. Leach's handwriting, has the peculiarity mentioned as distinguishmg. II. vulgaris from II. spinulosus, namely, that the middle flap of the tail is single-pointed and not divided into two lobes. 



\section{MIPPOLY'TE:}

\section{HIPPOT,YTE. Leach.}

Antenuc superiores breviores setis duabus: supcriore infra excavata.

inferiores corpore longiores setacea decrescentes, squama ad apicem externe unidentata pedunculo ammexa.

Palpi pediformes articulis tribus exsertis; ultimo penultimo multo longiore apice spinuloso: primo longo a basi ad medium emarginato.

Pedes decem: par anticum didactylum breve aquale: par secumhm inaquale didactylum ; carpo nulti-articulato: paria tertium, quartum et quintum simplicia (magnitudine sub)decrescentia) unguibus interne spinulosis instructa.

. bdomen 6-articulatum ; articulo secundo utrinque infra antice et postice producto ; articulo tertio postice gibboso-producto.

Couda pentaphylla; processu medio spinis in lineas duas longitudinales digestis; apice spinulifero.

\section{Generis Divisiones.}

* Pcdipalpi arliculo ullimo apice oblique truncato, antemuse superiores basi spina instructe. Cauda lamella intermedia medio supra utrinque bi-spinosa.

-* Pedipalpi articulo ullimo fasciculato-piloso. Antennce superiores basi lamella spiniformi instructe. Cauda lamella intermcdia supra utrinque 4-spinosa.

Superior antenua shortest, with two seta: the upper one excavated beneath. Inferior antemne longer than the body, sctaceous, with a lamella at their base, which is unidentated at its apex externally. Pediform palpes with three exserted joints: the last much longer than the second: the first notched from its base to the middle. Legs ten; the anterior pair short and didactyle; the second didactyle and unequal, with the wrist many-jointed; the other pairs simple, decreasing in size: the claws spinulose within. Abdomen six-jointed; the second joint on each side beneath produced; the third joint behind gibbosely produced. Tail with five plates; the middle one with spines arranged into two longitudinal lines.

Divisions of the Genus.

Last joint of pediform palpi, with its apex obliquely trumcated. Upper antenna with a spine at their base. Middle process of the tail above with four spines.

* Last joint of pediform palpi woilh fasciculi of hairs. Upper antennce with a spiniform lamella at their base. Niddle process of the tail with eight spines above.

Wrontagu sent to me Hippolyte varians, the type of this genus, as his Cancer astacus gibbosus, (Trans. Limn. Soc. ix. 91, t. 5. f. t, ) but he afterwards informed me, by letter, that his figrue and description had been made from mutilated specimens, of what he lad since ascertained to be a rery distinct species, and recpuested me to take the earlicst opportunity to correct his mistake. 


\section{HIPPOLYTE PRIDEAUXIANA. \\ Tав. XXXVIII.--Fig. 1, 3, 4, et 5.}

II. (*) rostro acuminato apicem versus subtus uni-serrato.

Fig. 1. Hippolyte Prideauxiana mag. nat. 3. Pedipalpus externus auctus. 4. Pes secundi paris auctus. 5. Rostrum amplificatum.

Mr. Charles Prideaux discovererl this species near Bantham, on the southern coast of Devon. and communicated it to me, along with a vast number of very curious Crustacea.

\section{HIPPOLYTE MOORII. \\ TAв. XXXVIII.--Fig. 2.}

H. (*) rostro acuminato ante medium subtus bi-serrato.

Fig. 2. Hippolyte Moorii mag. nat.

This species was found by Mr. Thomas Moore, amongst some rubbish dredged in the Plymouth Sound, and was given to me by Mr. C. Prideaux.

\section{HIPPOLYTE VARIANS. \\ TAв. XXXVIII.--Fig. 6---16.}

H. (*) rostro acuminato ante medium subtus bi-serrato ; pone medium et ad apicem supra uniserrato.

Hippolyte varians. Leach Edinb. Encycl. viii. 432.

- Trans. Linn. Soc. xi. 347.

Encycl. Brit. Supp. i. 421.

Fig. 6. Hippolyte varians mag. nat. (7 ad 16 auctæ.) 7. Antenna supcrior. S. Antenna exterior. 9. Pedipalpus. 10. Pedum par primum. 11. Pedum par secundum. 12. Par tertium cum illius ungue. 13. Par quartum. 14. Par quintum. 15. Cauda. 16. Rostrum.

Hippolyte varians is found in profusion in pools amongst the rocks, on the South-Western coast of Devon and Cornwall. It is very variable in colour, occurring with every shade of green, and of every tint between reddish and liver-brown.

\section{HIPPOLYTE CRANCHII.

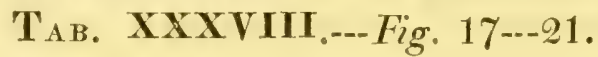

H. (**) rostro supra tri-serrato ; apice emarginato : lacinia superiore longiore.

Fig. 17. Hippolyte Cranchii mag. nat. 18. Pedipalpus auctus. 19. Pedum par secundum. 20. Pedum par tertium. 21. Rostrum.

Mr. John Cranch discovered this species on the southern point of the Saltstone, in the Kingsbridge Estuary, where it has likewise been observed by C. Prideaux, Esq. 

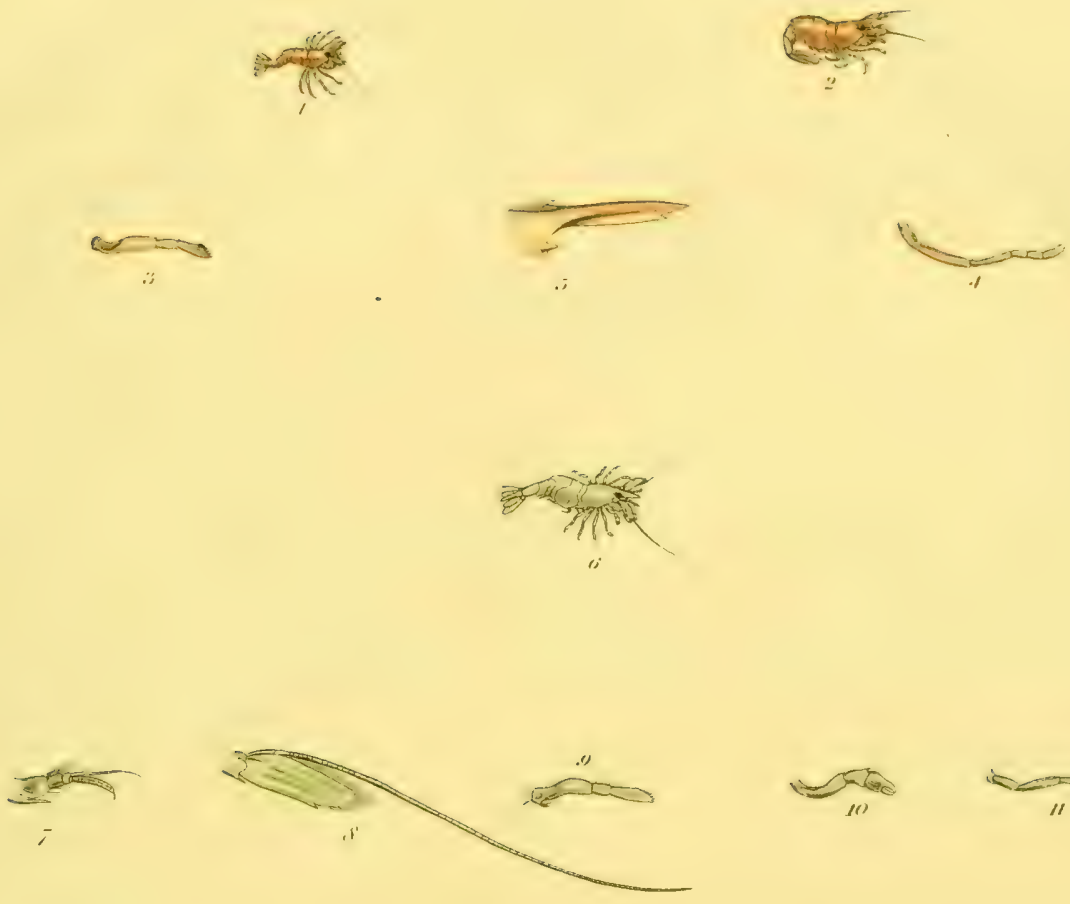

$\underbrace{58 \mathrm{e}}_{11}$
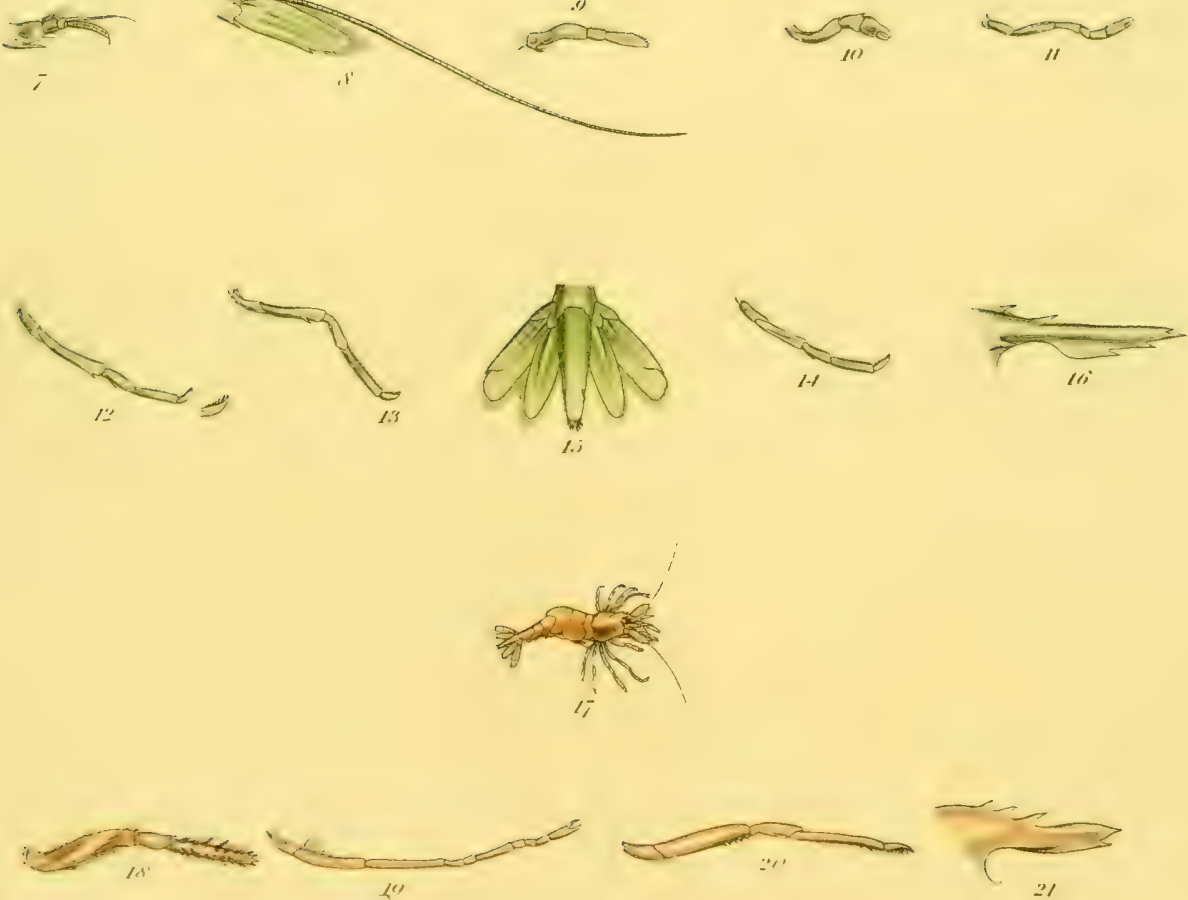




\section{HIPPOLYTE SOWERBEI. \\ TAB, XXXIX.}

II. $(* *)$ rostro alto obtuso supra mulli-serrato, apice emarginato serrulato; subtus uni-serrato. Cancer spinus. Sowerby Brit. Mise. Tab. 2111.

Alphæus spinus. Leach Edinb. Encycl. vii. 43I.

- Trans. Limn. Soc. xi. 347.

- Encycl. Brit. Suppl. i. 421.

Fig. 1. Hippolite Sowerhæi mag. nat. (Partes sequentes sunt amplificatæ.) 2. Antenna superior. 3. Antenna inferior. 4. Pedipalpus. 5. Pedum par anticum. 6. Pes secundus. 7. Pes tertius. 8. Pes quartus. 9. Pes quintus. 10. Cauda.

H. Soverbce was first described and figured in the above quoted work, by Mr. Sowerby, who received it from the Scottish coast, where it was found by Mr. Simmons, a young man who has since fallen a sacrifice to his zeal for Natural History in the West Indies.

The imperfect specimen from whence the annexed figure is taken, was sent to me by my liberal friend P. Neill, Esc. who took it out of the boat of a fisherman at Newhaven, in the Frith of Forth, and kept it alive in sea water for sereral days. Mr. Neill informed me that he had not met with one of this species for fifteen years. 

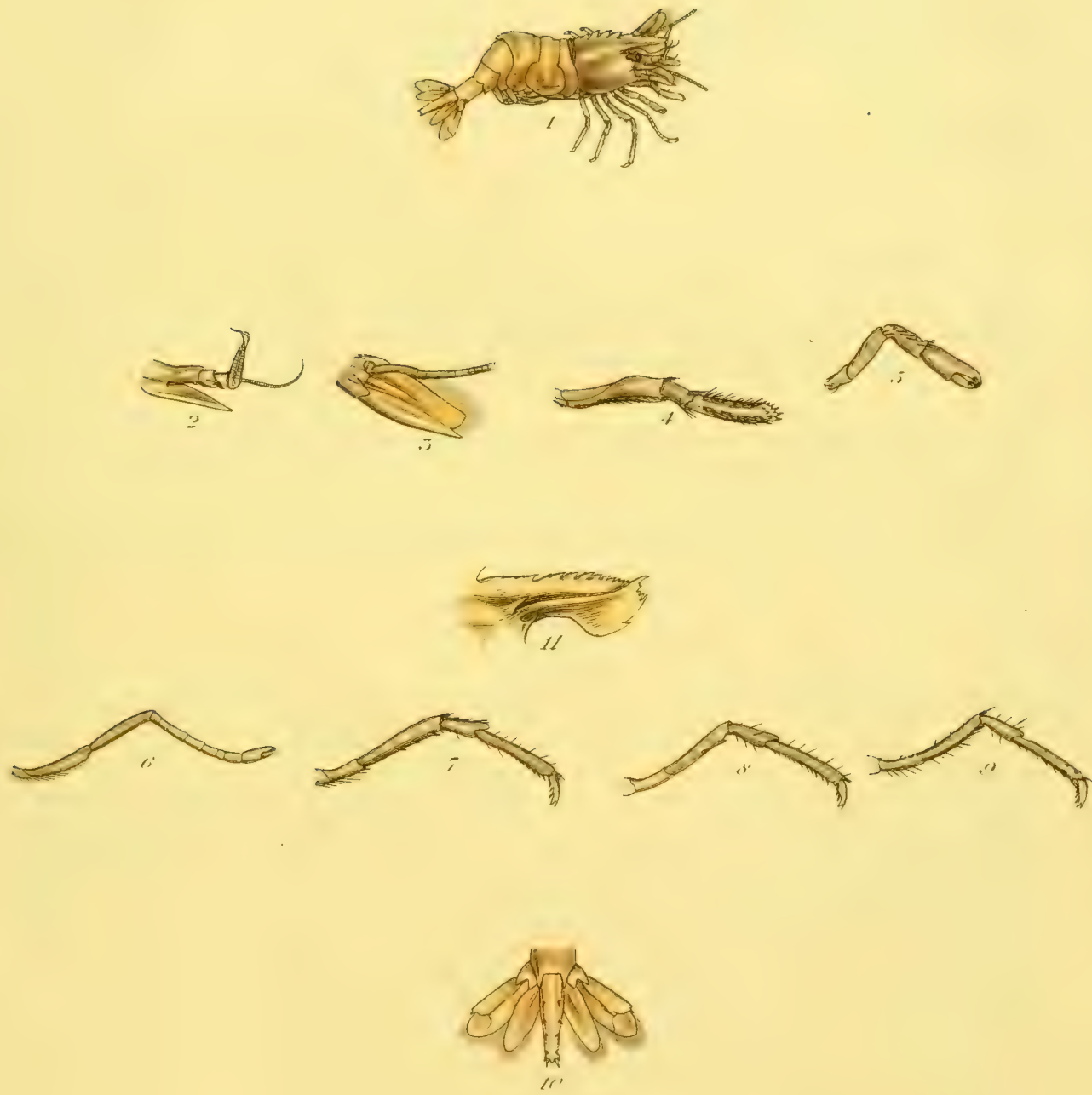



\section{PANDALUS.}

\section{PANDALUS. Leach.}

Antenne supcrioncs breviores setis duabus bifidis; pedunculus 3-articulatus, articulo primo majore ad oculorum receptionem excavato et sub oculis externe foliacco-producto; articulis secuurlo tertioque brevioribus aqualibus: seta superior brevior a basi usque ad medium incrassata et ad inferioris receptionem excavata :

Inforiores corpore longioces, seiacex, decrescentes, squama ad apicem externe unidentata pedunculo annexa.

Palpi pediformes articulis tribus cxsertis, articulis primo longiore a basi usque ad medium interne emarginato, secundo breviore, ultimo acuminato apice spinuloso.

Pides decem: par anticum adactylum, articulo extimo acuminato, simplici; par secundum didactylum inaquale, hôc lempissimo, tenuisimo carpo, cubito et brachiorum apice multiarticulatis; illô breviure, crassiore carpo cubitoque apice multi-articulatis; paria tertium, quartum et quintum simplicia (magnitudine subdecrescentia) unguibus interne spinulosis instructa.

Abdomen 6-articulatum, articulis secundo infra antice et postice ad latera producto, tertio postice gibboso-producto.

Cauda peutaphylla; processibus cxtemo externe bidentato; medio elongato apice basi duplo angustiore, spinis mobilibus instructo, dorsoque spinulis in lineas duas longitudinales digestis.

Superior antennæ with two seta ; the peduncle three-jointed, the first joint longest excarated above to receive the eyes and produced bencath the cyes into a leaf-like process, the second and third joints shorter and equal in length; the upper seta shortest, thickened from the base to the middle, excavated beneath for the reception of the inferior seta: superior antenna longer than the body, setaceous, and gradually decreasing towards their extremities, furnished at their base with a large scale, having its external point unidentate. Feet-like palpi with three exserted joints, the first of which is longest, cxcavated from the base to the middle; the second joint is shortest, the last acuminate with the apex spinose. Legs ten; first pair simple, adactyle; the second pair unequal, didactyle; one being very long and slender with the wrist, fore-arm and apex of the arm many-jointed, the other moderately long and thicker, having the wrist and apex of the fore-arm many-jointed; the three other pairs simple (slightly diminishing in size) furnished with nails which are spinulose within. Abromen six-jointed, the second joint with its lower sides behind and before produced; the third joint gibbous hehind. Tail composed of five plates, the external process externally bidentate, the middle process with the apex (only half the breadth of the base) armed with moveable spines, the upper part also with two rows of spines arranged longitudinally. 


\section{PANDALUS ANNULICORNIS.}

\section{TAR. XL.}

P. rostro multidentato ascendente apice emarginato; antennis inferis rubro amulatis, interne spinulosis.

Fig. 1, Pandalus annulicornis mag. nat. 2, antenna superior amplificata. 3, antenna infer. magnif. 4, Palpus pediformis amp. 5, Pes anticus adactylus. 6 et 7 , Pedum par secundum. 8, Pes tertii paris. 9, Pes quart. paris. 10, Pes quinti paris. 11, Unguis amplificatus. 12 et 13, Abdominis segmenti antici organa sexuum differeutias forte exhibentia? 14, Cauda amplificata.

This highly interesting species was discovered in Zetland, and in St. Andrew's Bay, Scotland, by the Rev. Dr. Fleming, who most kindly gave me the specimens $\mathbf{I}$ originally described in the Edinburgh Encyclopedia. It was observed also by Montagu, who found it on the coast of Devon; and by Mrs. D. Turner it was noticed at Yarmouth, and pointed out to Mr. J. D. C. Sowerby, as distinct from the common prawn.

It is used at Yarmouth as an article of food; and is at that place so much esteemed for the table, as to afford constant employment during the summer season to several fishermen, who take it in abundance at a considerable distance from the shore, and name it from that circumstance the sea-shrimp.

I have seen but one living specimen, which was taken at the junction of the rivers Tamer and Tavy in Devon: the whole animal was cinereous; antenna alternately amnulated with red and whitish; pediform palpi and four anterior legs spotted with deep red, the other legs with light red; thorax and abdomen speckled with red, the former on each side with two streaks, composed of red spots, placed on a testaceous ground, the latter also with several oblique streaks of a similar color.

The last joint of the pediform palpi is very bristly, and the spines at the apex are strong: the spines on the upper part of the middle process of the tail, in all the specimens that $I$ have seen, were ten in number: the denticulations on the upper part of the rostrum begin at the base, and are continued a little beyond the middle, and in some instances to within a third from the apex : the left of the second pair of legs, in those examined, was longest; between the eye and the squama of the inferior antenna, is a small spine. 


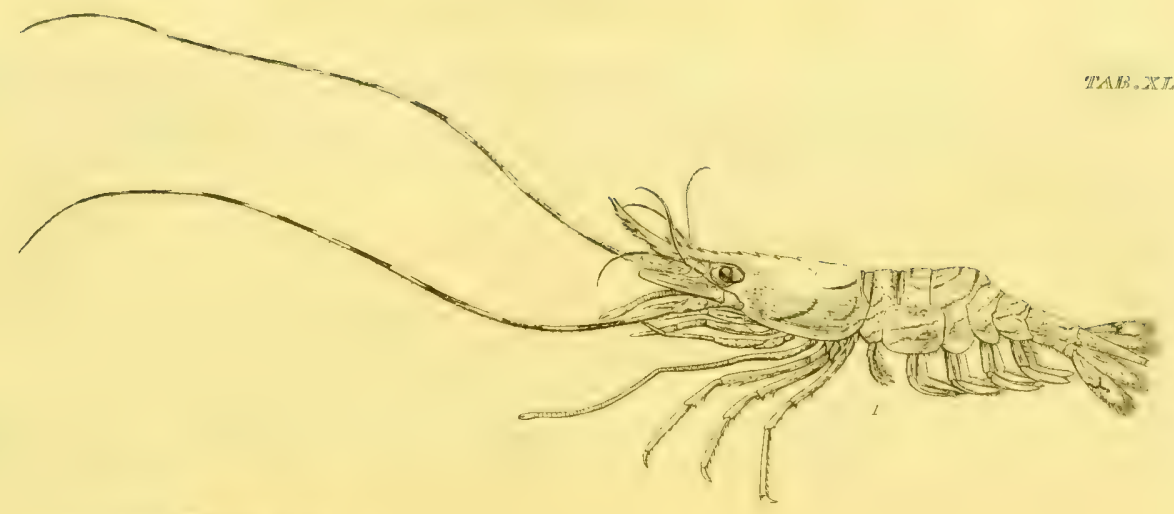

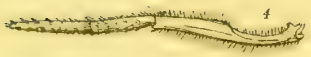
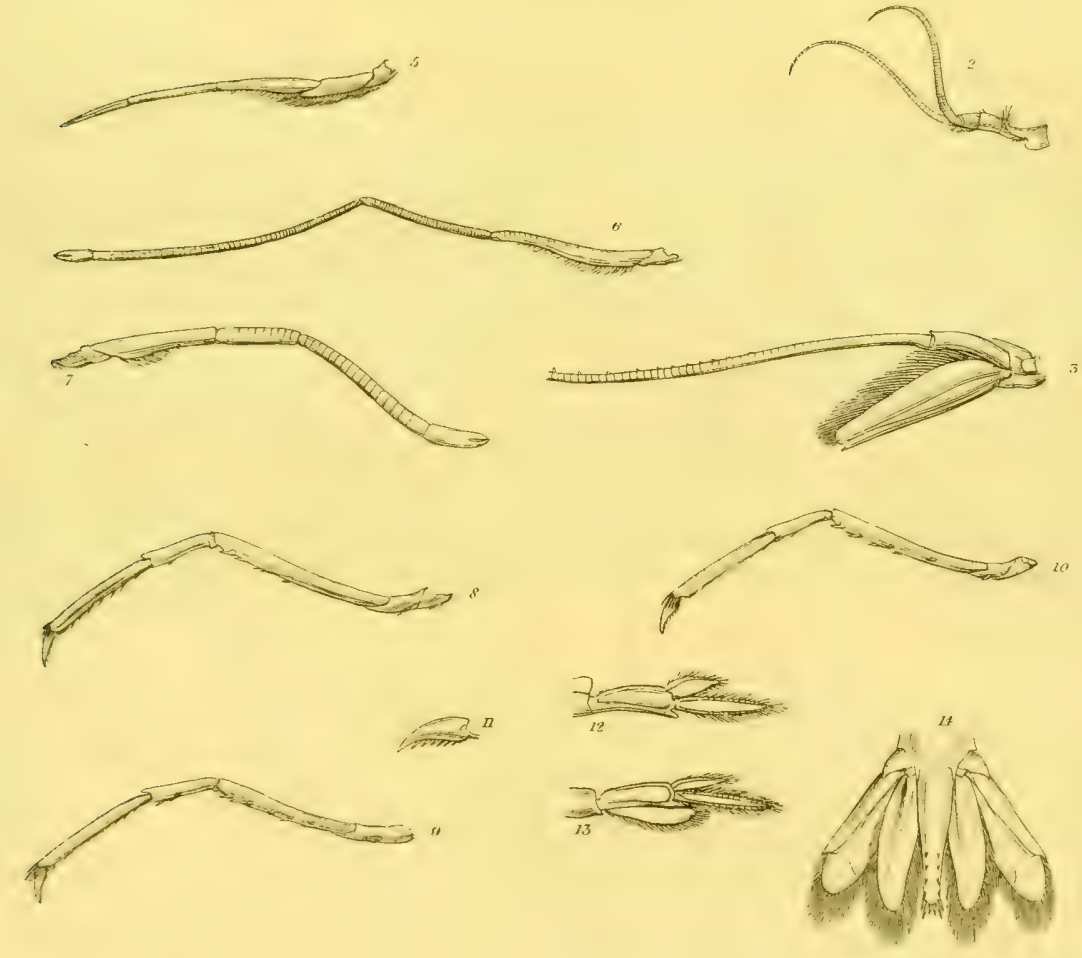



\section{PROCESSA.}

- Antenne superiores breviores setis duabas in eadem, fere linea horizontali insertis, seta interiore longiore: pedunculus 3-articulatus articulô primô longiore; ultimô breviore.

Infiriores corpore longiores, setacea decrescentes, squamâ ad apicem externe unidentatô pedunculo annex $\hat{a}$.

Palpi rediformes articulis quatuor exsertis, secundô longissimo ad basin interré subabrüte cmarginato.

Pctes decem; par anticum pede unô didactylô, alterô monodactylo; par secundum inequale, didactylum tenue, hôc longissimo carpố cubitôque multi-articulatis, illô hreviore carr $\hat{o}$ multi-articulatô: paria tertium, quartum et quintum unguibus acutis, simplicibus instructa. . 1bdomen 6-articulatum, segmento secundo infrá anticé et posticé producto.

Canda pentaphylla; processibus externis bipartitis parte exteriore mobili.

Superior antenna shortest, with two sete placed in nearly the same horizontal line; the interior seta largest: peduncle with three joints, the first of which is the largest, the third the shortest: inferior antenna setaceous and larger than the body, furnished at their base with a large scale, having its external point unidentate. Pediform palpi with four exserted joints; the second joint very long, somewhat abruptly emarginate at its base internally. Legs ten; anterior pair with one leg didactyle, the other monodactyle; second pair unequal, one being very long, having its wrist and fore-arm composed of many joints, the other having the wrist only jointed: third, fourth, and fifth pair furnished with sharp simple claws. Abdomen six-jointed, the second segment beneath anteriorly and posteriorly produced. Tail composed of five plates; the external plate composed of two parts, separated by a hinge-joint.

'The discovery of the species constituting this most curious and interesting genus, is the result of Montagu's indefatigable labors. The circumstance of the legs on different sides of the same animal being difierent in length is not an uncommon occurrence in several crustaceous gencra, but this is the first instance in which the legs of opposite sides have been found to differ in essential structure. 


\section{PROCESSA CANALICULATA.}

\section{TaB. XLI.}

P. rostro basi unidentato ; cauda lamella intermedia longitudinaliter canaliculata.

Fig. 1, animal mag. nat. 2, aritenna inferior amplificata. 3, antemna inferior aucta. 4, pedipalpus auctus. 5 et 6 , pedum par anticum ampl. 7 et 8 , pedum par secundum auctum. 9 , pes tertii paris auc. 10, pes quarti paris auct. 11, pes quinti paris auc. 12, Caudæ processus exterior auctus.

Montagu* discovered a single specimen of the above species at Torcross in the Southern coast of Devon, and with his usual liberality sent it to me for this work.

The thighs of the third and fourth pair of legs are spinulous beneath; at the base of the rostrum there is an elevation dividing it from the thorax or shell; the rostrum has evidently been broken, so that its exact direction is not known, although I suspect it to have been naturally bent abruptly downwards. The tip of the middle tail process is also broken.

* Since writing the abore, I have receiced intelligence of the death of this most zealous Zoologist, in whom science has lost an able supporter-the world an accomplished gentleman-and his friends a most valuable companion and correspondent. His Testacea Britannica and Ornithological Dictionary, not to mention his numerous papers published in the Transactions of the Linnean Society of London, leaze proofs of his industry and research that will cause his name ever to be remembercd and respected by British Zoologists. We still hope to see his observations on the British Mollusca and Vermes, which have long been prepared for publication. 


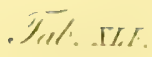
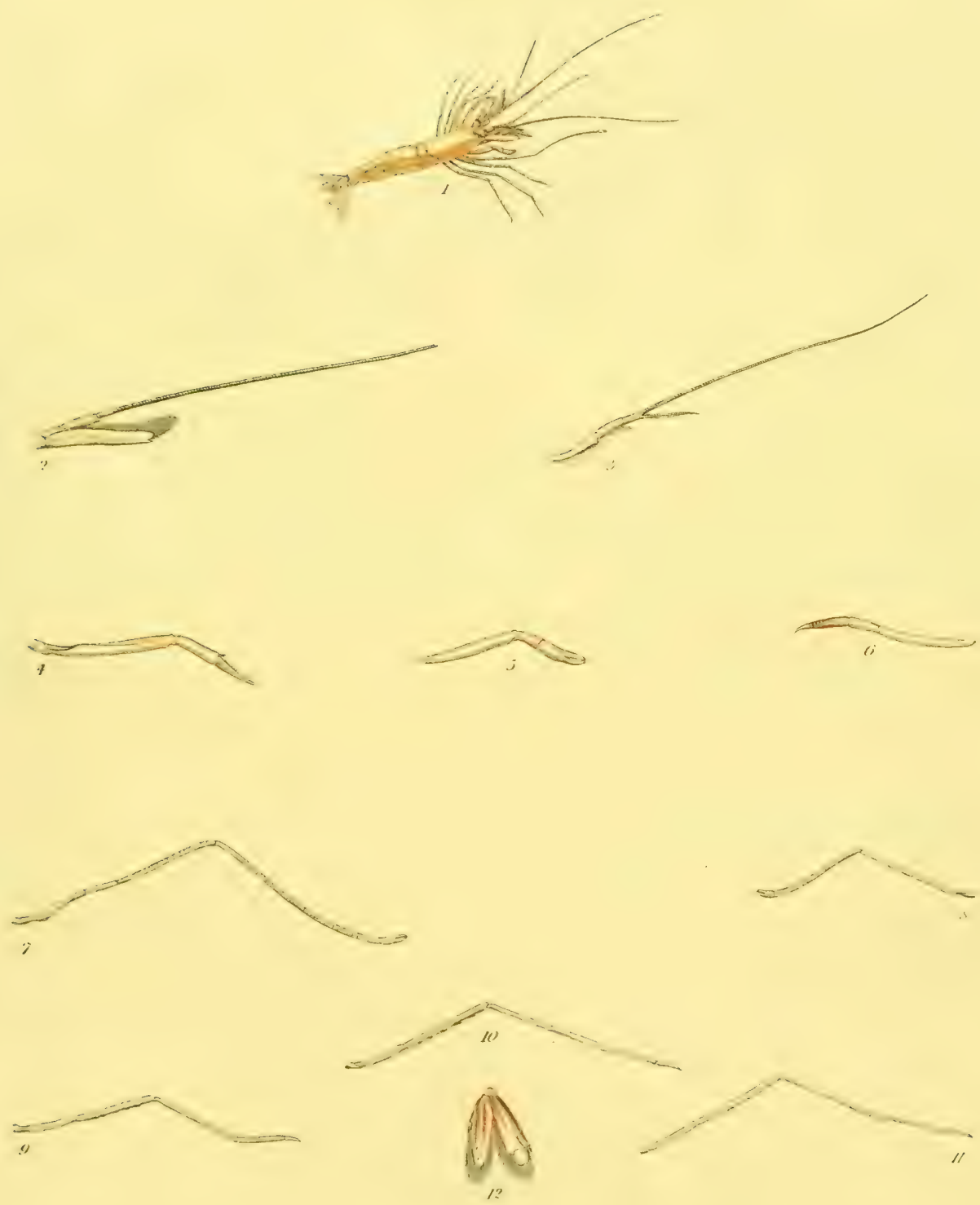

. 


\section{PENAUS.}

PENÆUS. Fabr., Latr., Bosc, Leach.

Antenne superiores breviores basi appendiculati : apice setis duabus acqualibus ; setâ superiore infernè excavatâ.

inferiores corporis longitudine, setacex, decrescentes ; squamâ magnâ ad illarum basin. Palpi pediformes articulis quinque exsertis; articulo ultimo obtusiusculo.

Pedes basi appendiculati: sex antici didactyli ; alii simplices; unguibus edentulis.

Abdomen sex articulatum.

Cauda pentaphylla ; lamellis duabus externis simplicibus ; lamellâ mediâ apicem versus utrinque spinulis mobilibus instructâ.

Upper antennæ shortest with an appendage at their base; apex with two equal setæ; upper seta excavated below. Under antennæ as long as the body, setaceous, decreasing towarcls their extremities, with a large broad squama at their base. Pediform palpi with five exserted joints, the last joint obtuse. Legs with a little appendage at their base: six anterior legs didactyle, the other legs simple, with toothless claws. Ahdomen six-jointed. Tail with five lamellæ; the two external lamella simple, the middle lamella towards its apex furnished with little moveable spines.

\section{PENAUS TRISULCATUS. \\ TAв. XLII.}

P. thorace postice trisulcato; rostro decendente supra multi-dentato.

Squilla Crangon. Rondel, xviii. 547. viii.

Penæus trisulcatus. Leach Trans. Linn. Soc. xi. 347.

Fig. 1. Penæus trisulcatus mag. nat. 2. Antenna superior. 3. Antenna inferior. 4. Pedipalpus. 5. Pes antici paris. 6. Pes secundi paris. 7. Tertii paris. 8. Quarti paris. 9. Quinti paris, 10. Cauda.

Pencus trisulcatus which is the only British species yet discovered, was sent to Mr. Sowerby by the Rev. H. Davies, who caught it on the shore of Anglesea. I have likewise received a specimen from the coast of Wales.

The fourth and fifth segments of the abdomen are notched on each side. 




\section{PALAEMON.}

PALFMON. Fabr, Latr, Lam., Bosc, Leach.

\section{ASTACUS. Pennant.}

Intenes superiores breviores setis tribus : duabus externis ad basin connatis ; int(rnâ breviore iuferiores corporıs longitudine, setacex, decrescentes; squamâ magnâ ad illarum basin. Palpi pediformes articulo ultimo penultimo breviore.

Pede's quatuor antici didactyli ; pari antico minuto ; paria alia simplicia ; unguibus edentulis Abdomen sex articulatum.

Cauda pentaphylla ; lamellis duabus extemis simplicibus, lamellâ intermediâ spinulis mobilibus instructê.

Upper antenna shortest with three seta, the two external seta joined at their bases, the interior one shortest. Under antenne as long as the body, setaceous, decreasing towarls their extremities; with a large squama at their base. Pediform palpi with the last joint shorter than the one before it. Four anterior legs didactyle; the first pair minute, the other legs simple, with simple claws. Abdomen six-jointed. Tail with five lamellar; the two exterior ones simple; the middle one furnished with little moveable spines.

The European Palcmones inhabit the shores of the sea during the summer months feeding on dead animal matter. The females seem to be much more abundant than the males, and are generally found with spawn.

\section{PALEMON SERRATUS. \\ TAB, XLIII.---Fig. 1---10.}

P. rostro ascendente supra 6,7 aut $S$-dlentato apice emarginato; infra 4, 5 vel 6-dentato.

Astacus serratus. Penn. Brit. Zool. iv. 19. Pl. 16. fig. 2S.

Palæmon squilla. Latr. Gen. Crust. et Insect. i. 54.

Leach Edinb. Encycl. vii. 401 .

Palæmon serratus. Leach Edinb. Encycl. vii, 432.

- Trans. Limn. Soc. xi. 348.

Fig. 1. Palamon scrratus mag. nat. 2 et 3 . Rostri varictates. 4. Antenua superior. 5. Antenna inferior. 6. Pedipalpus. 7. Pes antici paris. S. Pes secundi paris. 9. Pes tertii paris. 10. Unguis.

This is the common prawn of the London markets. It may always be distinguished from the other British species by the form of its rostrum, which, although subject to comsiderable variation in the number of teeth, yet always turns upwards, and has its point generally notched. ${ }^{*}$ It has been confounded with the following species by several writers. 


\section{PALAMON SQUILLA.}

Fig. 11---13.

P. rostro recto apice emarginato supra 7 aut 8 infra 2 vel 3-dentato.

Cancer squilla. Limn. Syst. Nat. i. 1051.

Palæmon squilla. Leach Edinb. Encycl. vii. 432.

Trans. Linn. Soc. xii. 448.

Fig. 11. Palæmon squilla mag. nat. 13 et 14. Rostri varietates.

The above specics which is found in abundance on the South-Western coast of Devonshire, is thus described by Linné in the second edition of Fauna Suecica: "Thorace lævi rostro supra serrato ; subtus 3-dentato, manuum digitis æqualibus." "Rostrum lanceolatum, perpendiculare, acutum, supra octo crenis, infra tribus serratum." Linné repeats in the last edition of his Systema nature the same character, and as it applies so exactly to the most common variety of this species, there cannot be the least doubt as to the correctness of the reference.

\section{PALAMON VARIANS.}

$$
\text { Fig. 14.---16. }
$$

$P$. rostro rectro supra 4,5 aut 6 -dentato apice integro ; infra bidentato.

Palæmon varians. Leach Edinb. Encycl. vii. 401,-431.

- Trans. Linn. Soc. xi. 349.

Fig. 14. Palæmon varians mag. nat. 15 et 16 . Rostri varietates.

Palcemon varians is very common on the Devonshire, Glamorgan, and Norfolk coasts, where it is taken as an article of food. It may be Astacus Squilla of Pennant? 

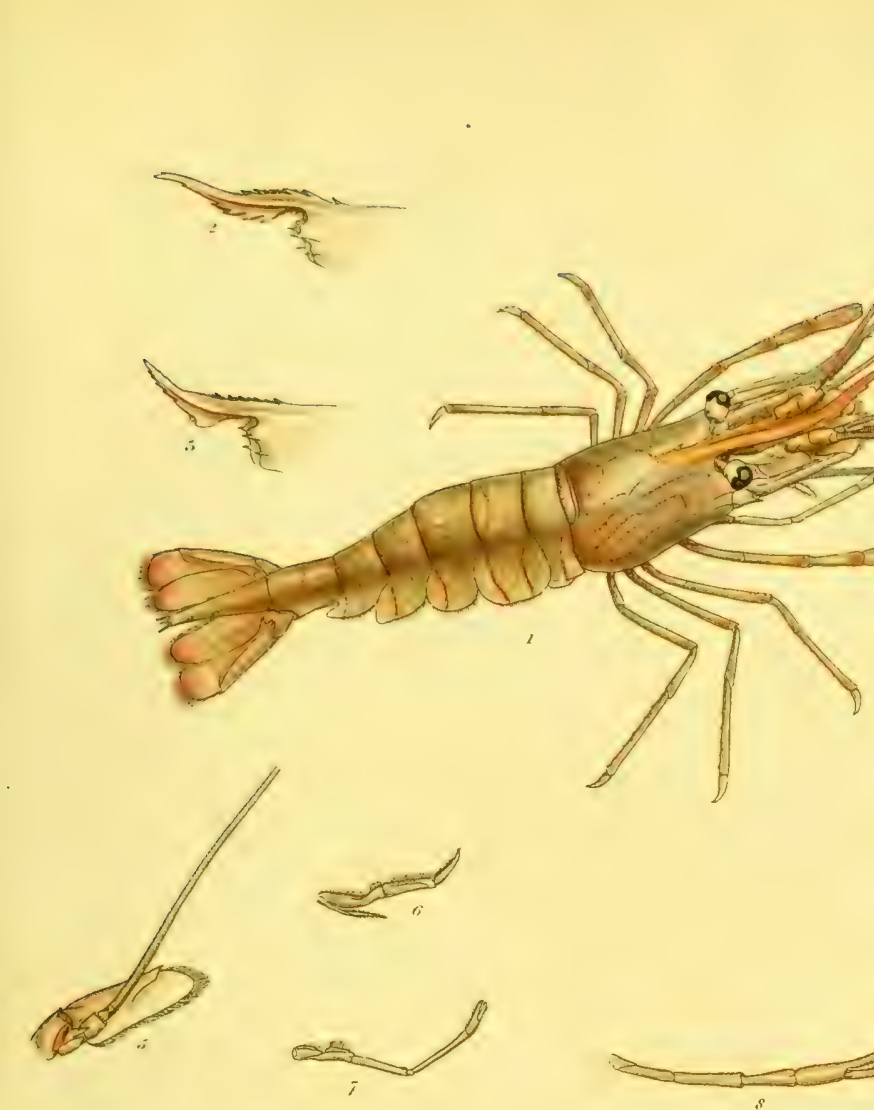

. Nit:IVIIII.
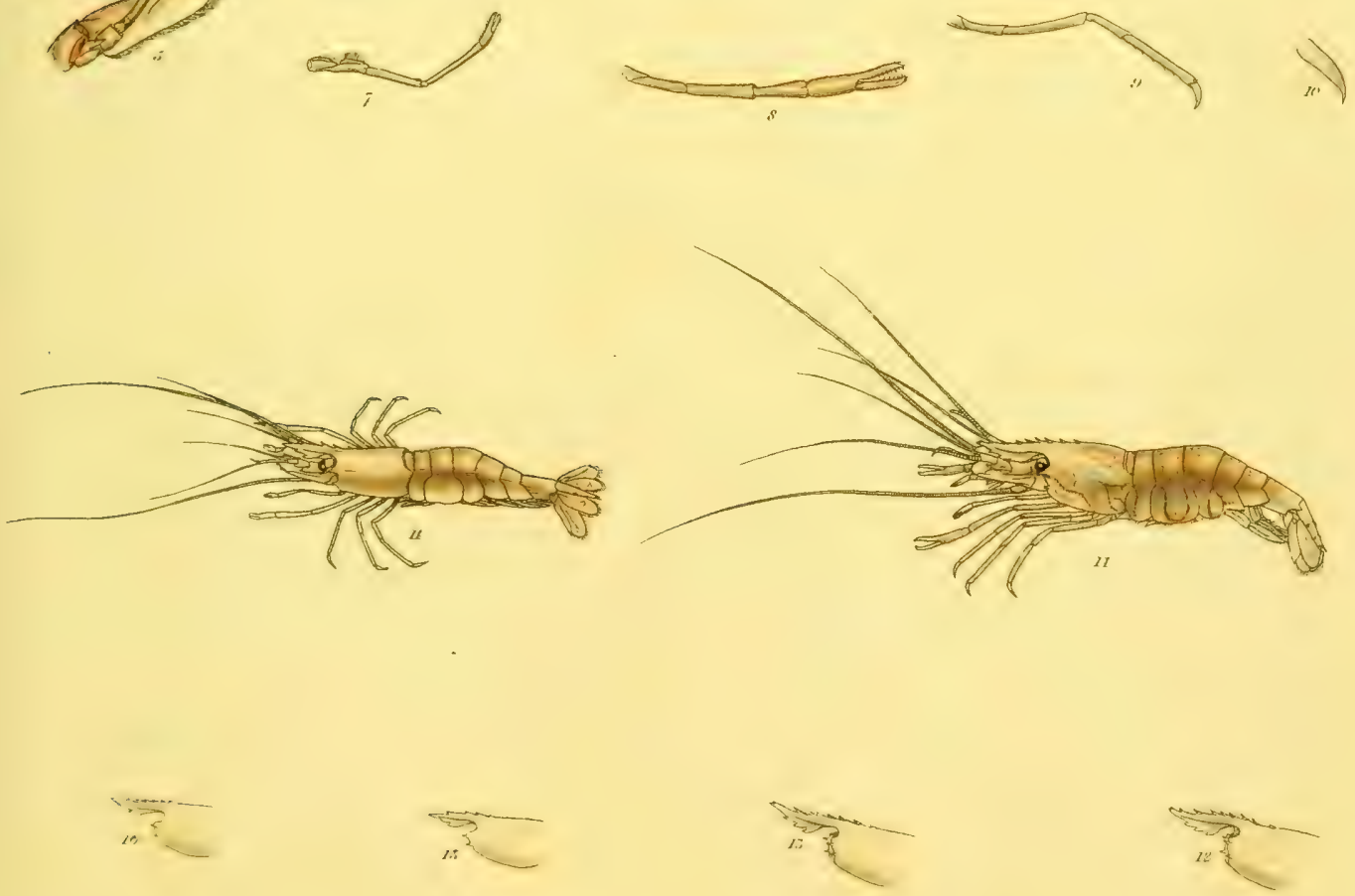
, 



\section{ATHANAS.}

ATHANAS, Leach.

Antennce superiores setis tribus instructæ:

inferiores corpore subbreviores setaceæ, basi squamâ magnâ apice externé unidentatâ instructæ.

Pedipalpi articulo ultimo penultimo longiore.

Pedes decem; par anticum majus didactylum; par secundum aliis gracilius didactylum, carpo multi-articulato: paria alia consimilia ungue simplici terminata.

Abdomen 6-articulatum apice pentaphyllum : lamellâ exteriore bipartitâ.

Test $a$ anticè rostro terminata.

Upper antennæ terminated by three setæ : under ones setaceous, rather shorter than the body, and furnished at their base with a large scale, having a tooth on its external apex. Pedipalpes with their last joint longer than the preceding joint. Legs ten ; anterior pair largest didactyle ; second more slender than the others, didactyle, the wrist many-jointed; other legs alike and terminated by a simple claw. Abdomen six-jointed; the apex with five plates; the exterior one composed of two parts. Shell anteriorly terminated by a rostrum.

\section{ATHANAS NITESCENS.}

\section{TAB. XLIV.}

A. rostro recto inermi.

Cancer (Astacus) nitescens. Montagu, MSS.

Palæmon nitescens. Leach Edinb. Encycl. vii. 401.

Athanas nitescens. Leach Edinb. Encycl. vii. 432.

- Trans. Limn. Soc. xi. 349.

Encycl. Britan. Suppl. i. 421.

Fig. 1. Athanas nitescens mag. nat. 2. A. nitescens auctus. 3. Antenna superior auct. 4. Antenna inferior auct. 5. Pedipalpus auctus. 6. Pes anticus auctus. 7. Pes secundus auctus. 8. Pes tertii paris auct. 9. Quarti paris ampl. 10. Quinti paris ampl.

Athanas nitescens is occasionally found in pools left by the tide amongst the rocks on the coasts of Devon and Cornwall.

It was discovered by Montagu, who sent it to me under the specific title ritescens; the reason for this name is unknown. 

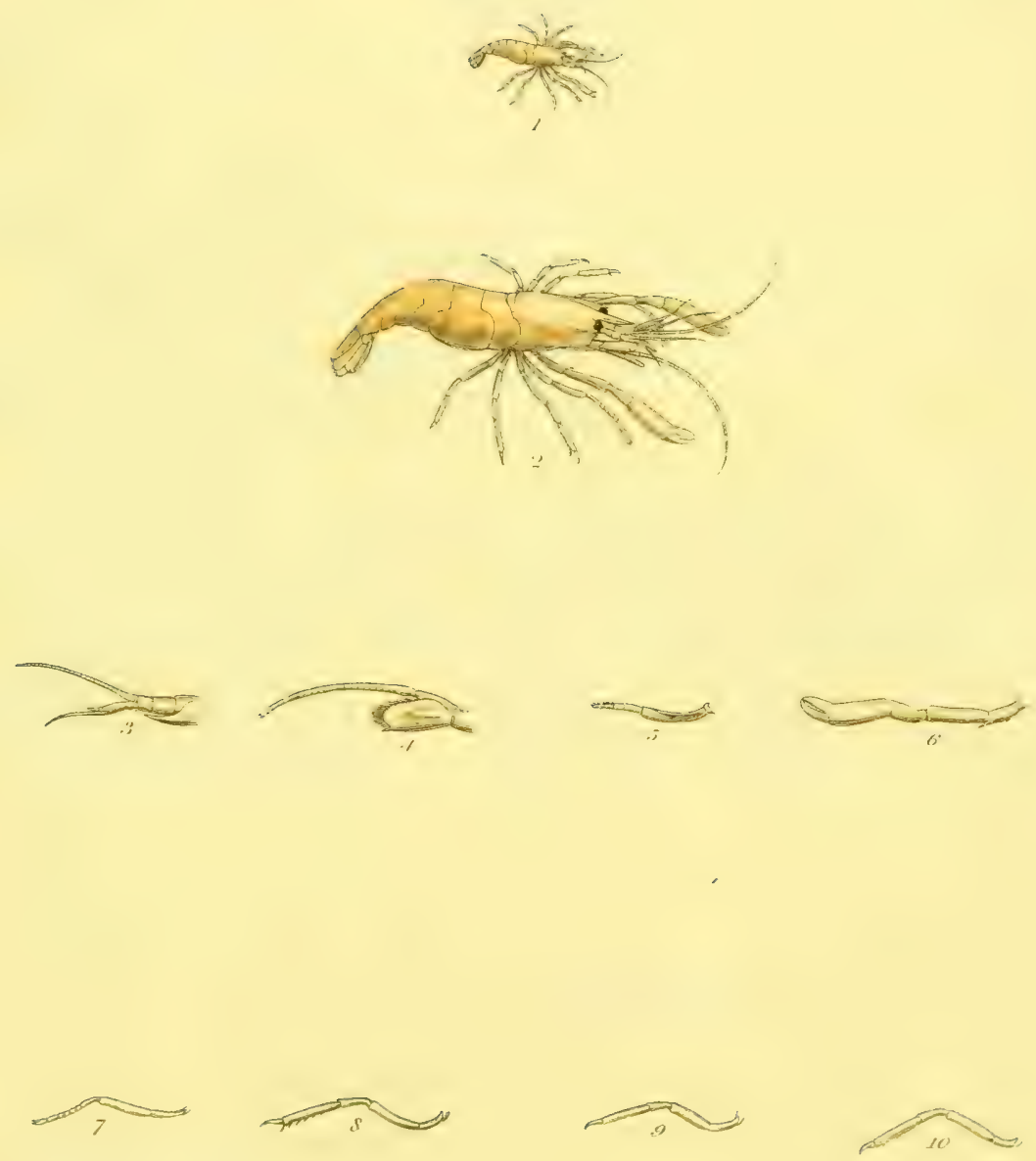



\section{SQUILLA.}

SQUILLA, Rondelet, Fabricius, Latreille, Leach.

CANCER, Herbst.

Segmentum antennarum mobile, fere quadrilaterale.

Antenne extorne ad latera segmenti, subtus testæ marginern anticum insertx.

Pedum thoracis par primum magnum, complanatum digito prehensili elongato, mobile, dentibus tenuibus armatis armato munitum; paria $2,3,4$, manu rotundo unidigitato ; paria 5, 6, 7, parvis, tenuibus articulo antepenultimo appendici styliformi munito.

Testa longior quam lata, sulcis duobus longitudinalibus divisa.

Abdomen arcuatum, elongatum, segmentis novem.

Cauda flabelliformi, segmenti mediano lato, dentato.

Antenual segment moveable, almost quadrilateral. External antennæ fixed at the sides of the segment, inserted under the anterior margin of the carapace; first and second joints of the peduncle short, the second with an elongated ciliated plate. First pair of thoracic feet large and Ilat, provided with a long, moveable, prehensile finger armed with thin curved teeth. Second, third, and fourth pairs with a round, flattened single-fingered hand; fifth, sixth pairs thin, small, antepenultimate joint provided with a styliform appendage. Carapace oblong, divided by two longitudinal grooves. Abdomen arched, elongated, with nine segments. Tail fan-shaped, with the middle segment broad, toothed.

\section{SQUILLA MANTIS.}

TAB. XLV. FIG. 1-3.

S. abdomine longitudinaliter octo-cristata; cristis centralibus approximatis. Pedum pari primi digiti prehensili sex-dentata.

Cancer (Mantis) digitalis, Herbst, II. t. xxxiii. f. 1, p. 9, e. Squilla mantis, Rondelet, Poissons II. t. xxxiii. p. 397, Latreille, Hist. Crust. VI. t. 55, f. 3. Fig. 1, Squilla mantis. 2, Pes secundus. 3, Manus. 
The prehensile claw of this crustacean is rery curious. It is capable of being bent back, with its elegrantly curred teeth into a groove in the long flattened hand. The groove has a little noteh to receive the point of each tooth. There are also three moveable teeth at the extremity of the hand. The scizing and retaining power of this apparatus must be very considerable. The Squilli mantis, tolerably common in the Mediterrancan, oceurs but rarely on the south-western consts of Great Britain.

\section{SQUILLA DESMARESTII.}

FIG. 4.

S. abromine al latcra longitudinnliter cristatum medio lievigato, segुmenti penultimo octocristato; digito prehensili quinque-dentato.

Squilla Desmarestii, Risso, Crust. Nice, t. 11, f. 8, p. 114, Couch, Corn. Faun. p. 81. Fig. 4, Squilla Desmarestii.

Like the preceding, this species is common in its Mediterranean home, while it occurs but rarely on the British const. It differs from S. mantis in the central arch of the abdominal segments being uncrested, and in haring five instead of six long teeth on the prehensile finmon 
Jüb.xLv.
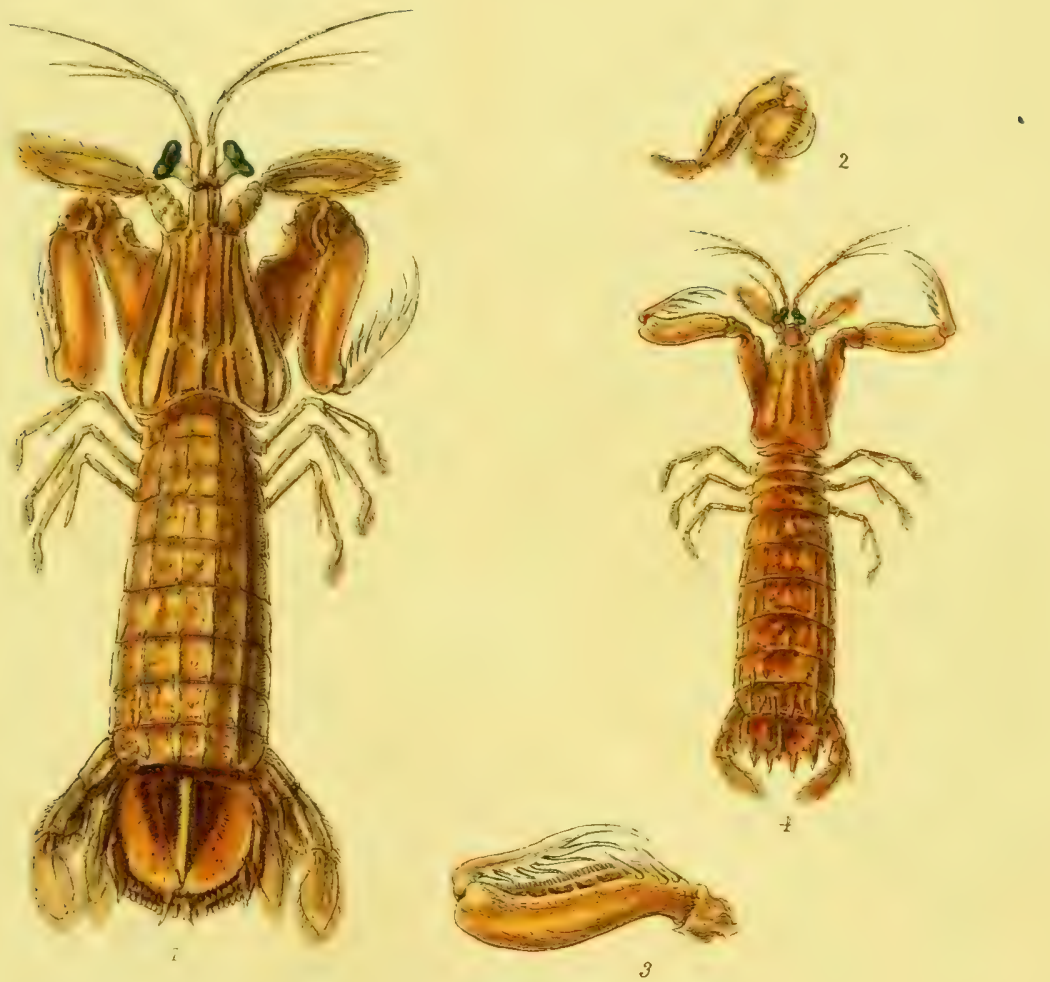



\title{
No. XII.
}

(Price Seven Shillings and Sixpence colored, and Six Shillings plain)

\section{MALACOSTRACA PODOPHTHALMA}

\section{BRITANNIAE;}

ore

DESCRIPTIONS OF THE BRITISII SPECIES OF

\section{Crabs, 石obsters, Jaratung,}

\author{
AND OF OTHER: \\ MALACOSTRACA WITII PEDUNCULATED EYES,
}

BY

WILLIAM ELFORD LEACH; M.D. F.L.S. \& W.S.

Fillos of the Royal College of Physicians of Edinburgh, and of the Royal College of Surgeons, and of the AFedicen chinurgical Society of London, \&c.

ILLUSTRATED

WITH COLORED TIGURES OF ALL THE SPECIES,

IIS

JAMES SOWERBY, F.L.S. G.S.W.S. \&c.

Monorary Member of the Physical Socicty of Götinger; Author of English Fungi, British MTineralogy, Exoluc Mincralogy, Mineral Conchology, a Botrinical Dr.wing.Book, a New Elucidation of Colors;

Proprietor of Englist Botiny, sc.

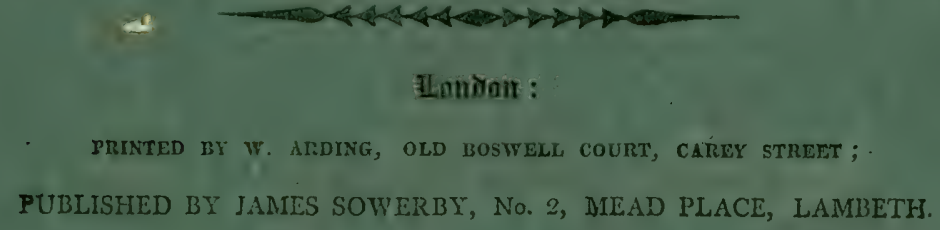

Novi 1,1816 



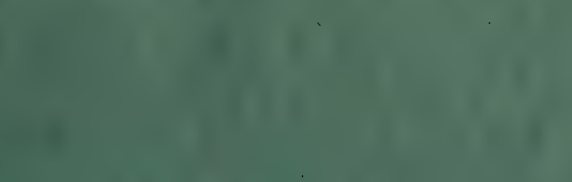

.

.

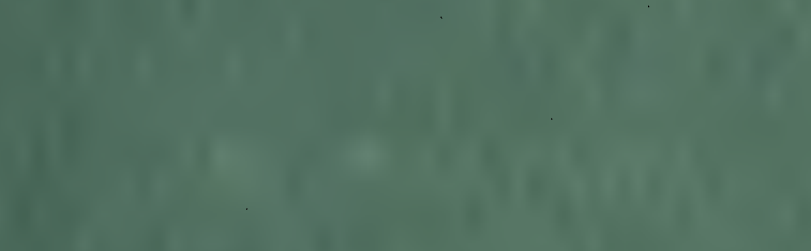

.

.

.

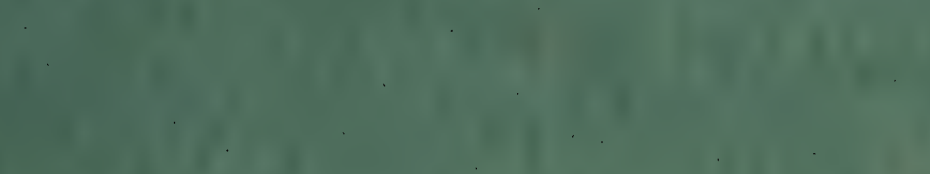

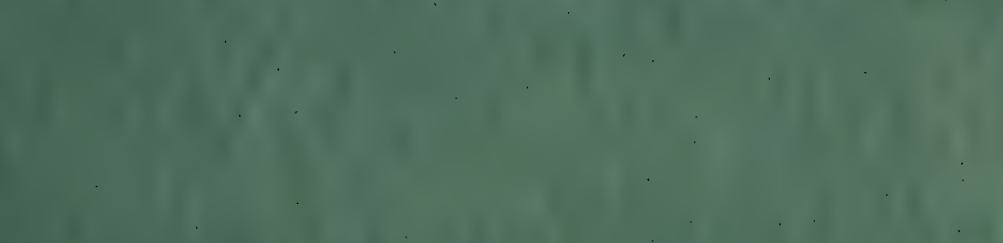

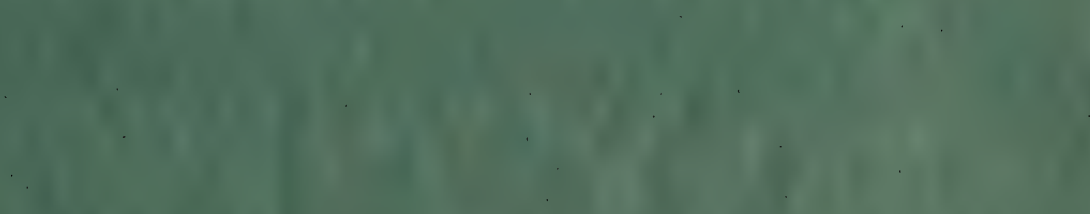

.

. $\quad . \quad 0$.

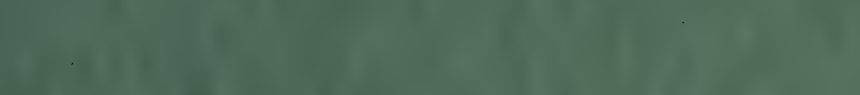




\section{ADVERTISEMENT.}

Tars Work will consist of twelve or fourteen Numbers (one Number to be published every two Months), which will form, when complete, one moderately-thick Volume.

Although this Work is to be published miscellaneously, yet the Plates are numbered, to enable the Purchaser to arrange it systematically, when complete.

The following species, viz. Astacus Arctus, and Mrntis of Pennant, seem to have been introduced into the British Fauna on slender authority, and fragments of a species of the genus Squilla which were found by the late Mr. Boys in a Torbay trawl-boat, are preserved in the cabinet of Montagu : information therefore on these or on other species is very desirable, and we shall feel obliged to any Naturalist who shall vender us any ascistence in making this publication as complete as possible.

The mode of obtaining Crustacea is ensy; Crab and Prawn-Pits, also the rubbish taken from the bottom of the sea by dredgers, should be carefully examined, as either ne: $w$ or rars species often occur, and are rejected by the Fishermen as useless; when obtained they should be immersed in fresh water, for the purpose of extracting the salt, after which they should be dried in the shade, and if possible, in a draft of air. 


\title{
No. XVIL:
}

(Price Seven Shillings and Sixpence colored, and Six Shillings plain)

\section{MALACOSTRACA PODOPHTHALMA \\ BRITANNIE;}

oR

DESCRIPTIONS OF THE BIITISII SPECIES OF

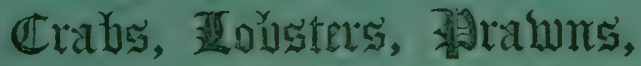

\author{
AND OF OTHCE
}

MALACOSTRACA WITH PEDUNCULATED EYES,

BY

WILLIAM ELFORD LEACH, M.D. F.R.S. F. L.S. \& W.S.

Teliow of the Royal College of Physicinns of Edinbursh, and of the Royal Colleze of Surgeons of London; correspondent

Viember of the Museum, an: Philomutic Sucie'y of Paris; of the Berlin Sociecy of Naturalists, and of the Academy of Naiural Sciences of Philadelplini, \&c.

ILLESTRATEO

WITH COLORED FIGURES OF ALL THE SPECIES,

a

JAMES SOWERBY, F.L.S. G.S. W.S. \&c.

IImorary Member of the Physical Society of Göttingen; Author of Enylish Fung2, British MInineralogy, Exotic

ATineralogy, Mineral Conchology, a Botanical Drinuing-Book, a New Elucidation of Colors;

Proprictor of English Botany, \&;.

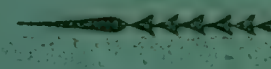

\section{FlonDon :}

PRINTED BY W. ARDING, OLD BOSWELL COURT, CAREY STREET.

PUBLISHED BY JAMES SOWERBY, No. 2, NIEAD PLACE, IAMIBETS.

$\therefore \quad$ Mareh 1,1820 



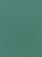
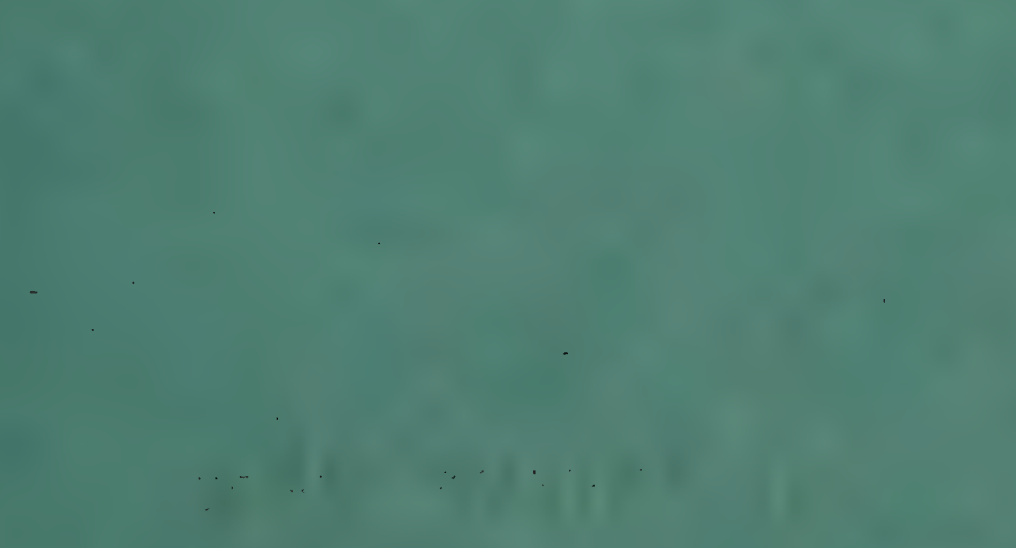

$x^{2}+x^{2}$

$+\quad . \quad+\quad . \quad+$

.

$\therefore$

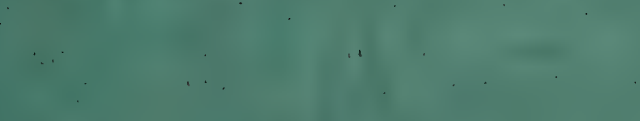

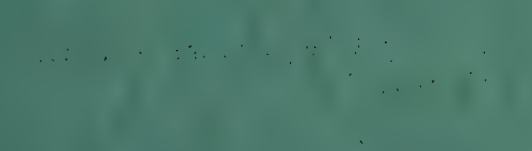
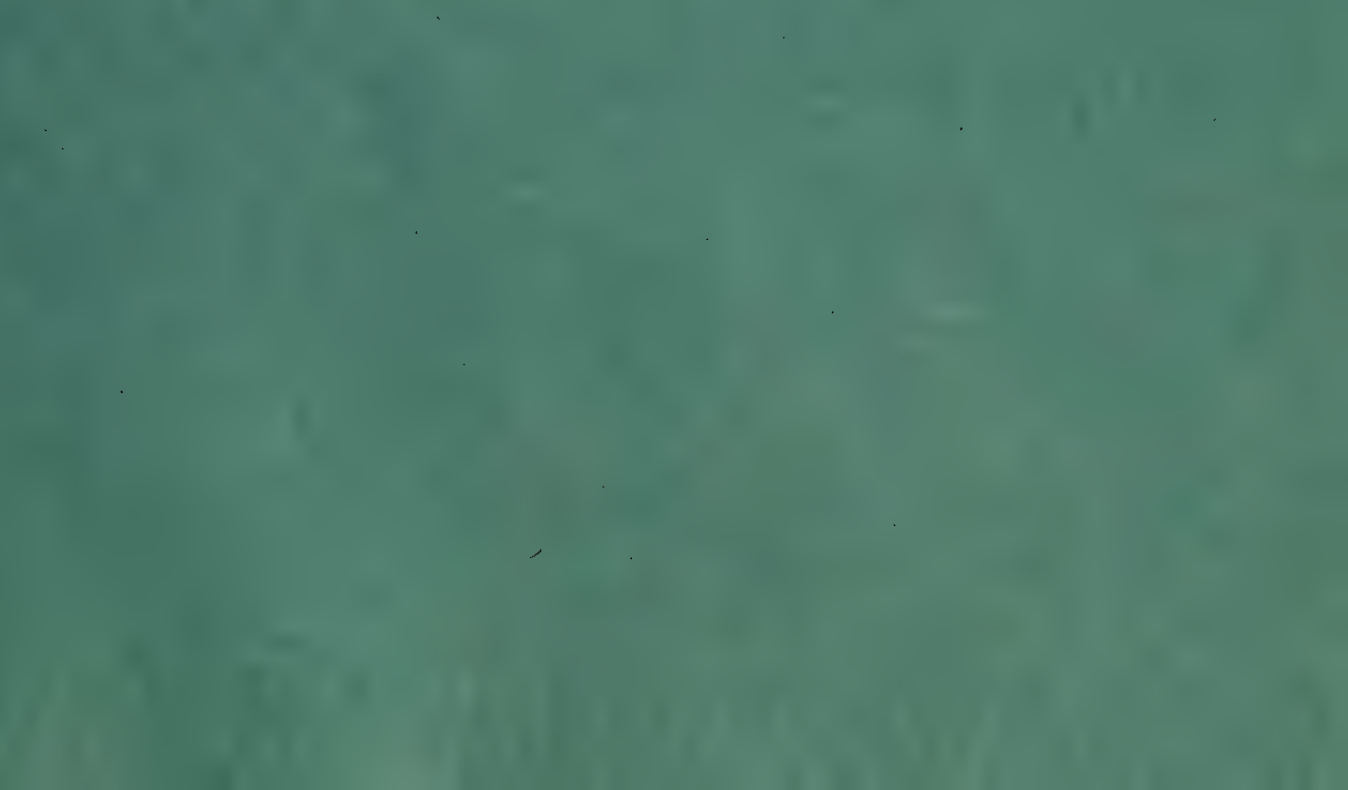

4it

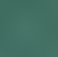




\section{ADVERTISEMENT.}

WHEN this Work commenced, it was the intention of the Author to have completed it in twelve or fourteen numbers, but the discovery of several new species has rendered this impossible, and he will, consequently, be under the necessity of extending it to nineteen numbers, one of which will be published as usual, on the first day of every second month, and the new matter will be introduced in such a manner as not to disturb the systematic arrangement of the work, which, when completed, will form one volume; to which some general remarks on the British Crustacea, and an Index of Synonyms will be added.

Although the Work is to be published miscellaneously, yet the plates are so numbered, as to enable the purchaser to arrange it systematically, when complete. 


\title{
Nos. XVIII. \& XIX.
}

Prico two guineas.

\section{MA I ACOSTRACA PODOPHTHALMA BRITANNIE;}

olr

DFSTHPTONS OE THE BRTTSH SPECIES OF

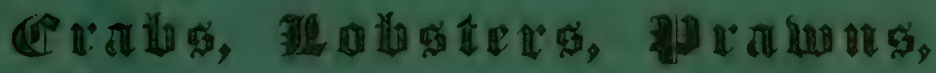

\author{
AND OF CORER
}

MALACOSTRACA WITH PEDUNCULATED EYES,

BY

WILLIAN EIFORD LEACH, M.D. F.R.S. F. L.S. W.S., \&c. IL.LUSTRATEก

WITH COLORED FIGURES OF ALL THE SPECIES,

BY

JAIES SOWERBY, F.L.S. G.S. IV.S. \&c.

Author of Einglish Fungi, Eritish Ifineralogy, Exotic Mineralogy, Ifineral Conchology, S.c.

CONTINUED AND COMPLETED, WITH $\Lambda \mathrm{NEW}$

GENERIC AND SPECIFIC INDEX TO THE WHOLE, AND SEVEN NEW PLATES,

$\mathrm{BZ}$

GEORGE BRETIINGHAM SOWERB Y, F.L.S.

\section{五)}

PUBILISHED BY BERNARD QUARITCH, IS PICCADILIY, 


\section{$\overline{X X I V}^{a}, \overline{X X V I I}, \overline{X X X I V}, \overline{X X X V}, \overline{X X X V I I,}$ $\bar{X} \overline{\mathrm{V}}$. yrich, Index}

还ibrary of the e ctluscum

$\mathrm{OH}$

\section{COMPARATIVE ZOÖLOGY,}

IT IIARYARD COLLEGB, CAMBRIDGE, HASS.

Jounder by pribate subscription, fin 1861.

Deposited by ALEX. AGASSIZ.

No. 64054

No. 640 



\section{ADVERTISEMENT.}

The Author of this work amounced in 1S!C, on part XVII, that it was his intention to complete it in nineteen parts; howerer, lie stoplyed short then. Upon the stock beconing my property, I alopted the sugrestion of Mr. George Brettingham Sowerby, the eminent Naturalist, that the work should be continued, by the addition of such species as formed part of the author's original plin: that gentleman has now drawn for the work fifteen new

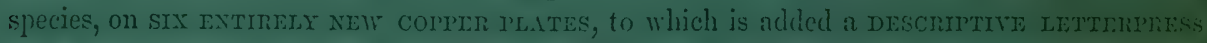

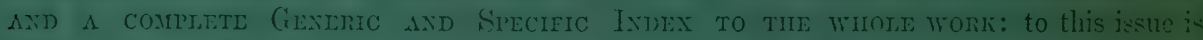

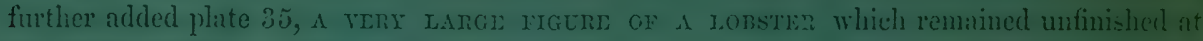
the alurupt cessation of the work.

The new matter is arranged in such a manner, that while the gaps in the numbering of the plates are filled up, the systematic arramgement is not disturbed; and by means of these additions the unfinished work of Lench and the elder Sowerlyy is arranged and completed.

Possessors of imperfect copies should arail themselves of the present opportunity of completing them, as only a small number of parts 18 and 19 were printed in excess.

$\Lambda$ few copies of parts 18 ant 19 were printed on LARge PAren, super royal quarto.

LiONDon, 15 Picciditir, W.

Bengari) (Qughtiteit.

November 1,1875 . 


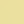







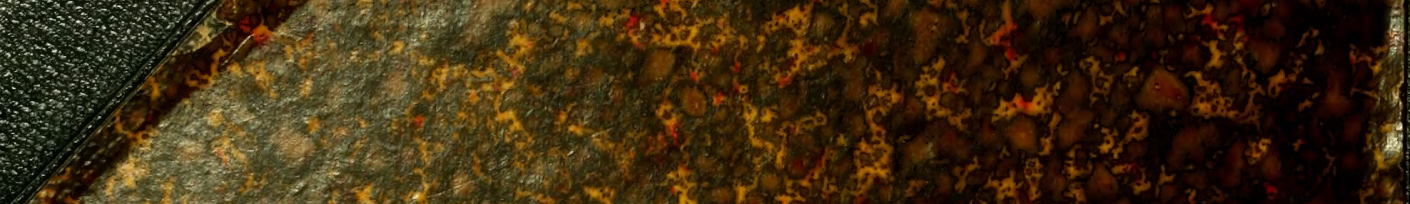

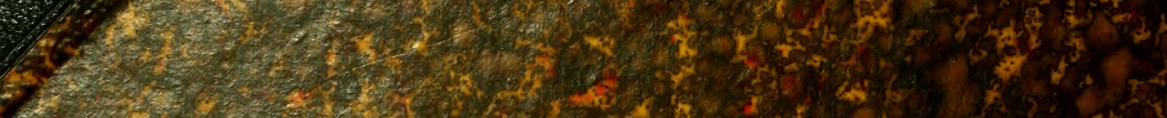

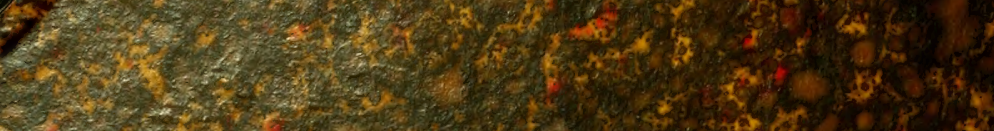

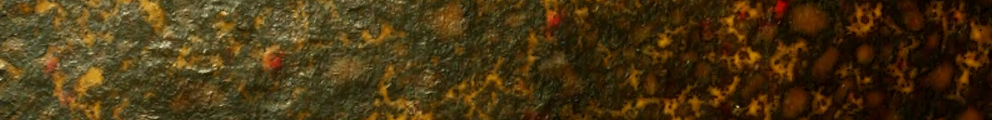

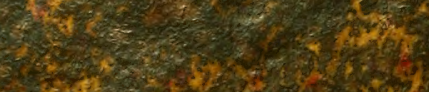

(2)

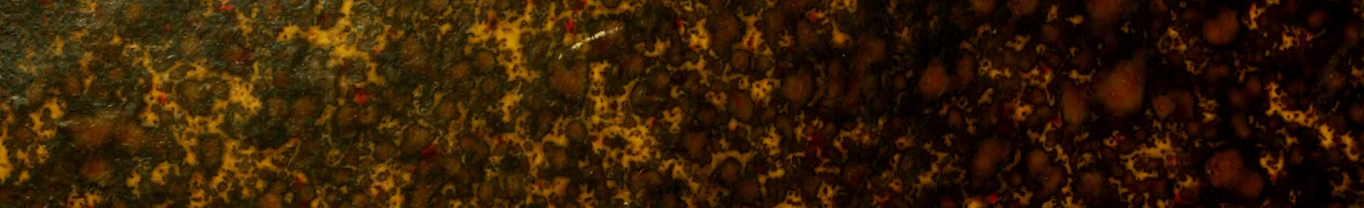

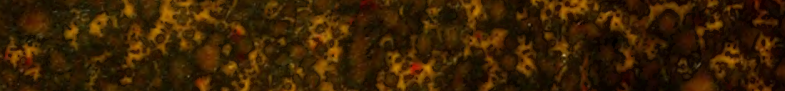

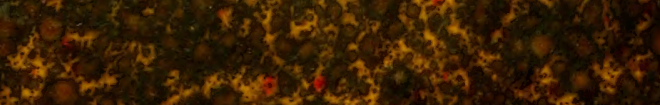

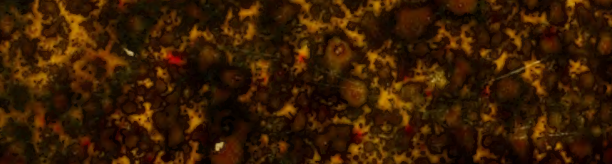

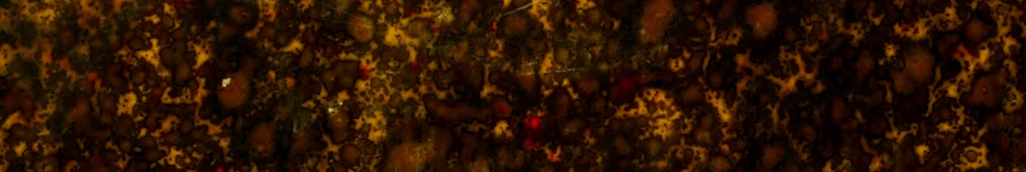

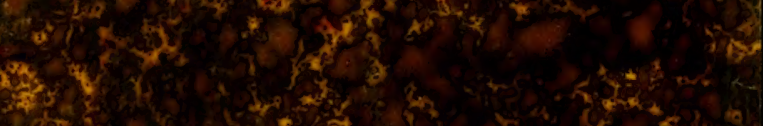

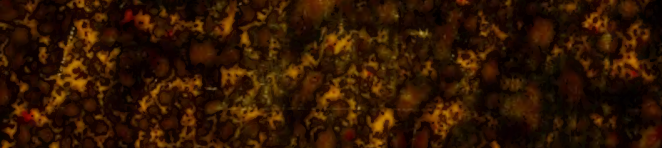

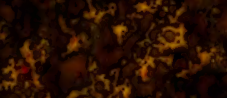

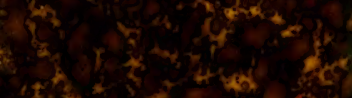

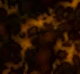

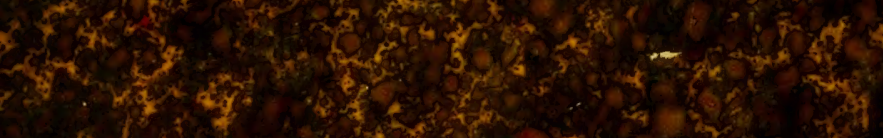

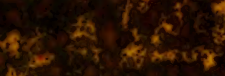

510

(5) 3 is 3

G.

Y.t. $x^{2}+y^{2}+2$

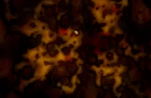

.

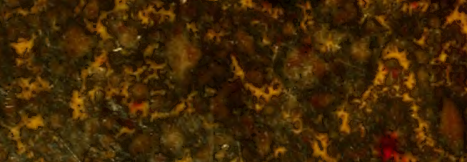

$x^{2}+x^{2}+x^{2}$

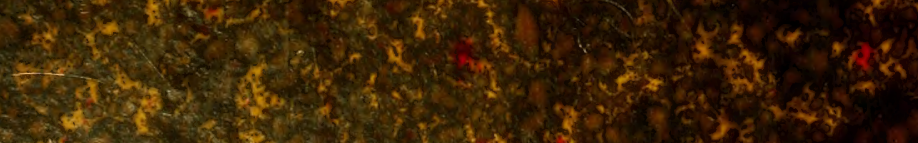
$2+2+3 x^{3}$

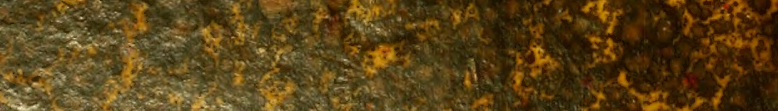

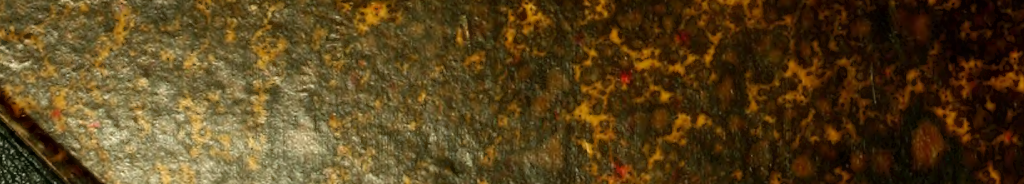

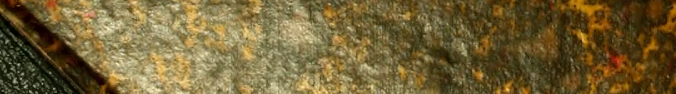

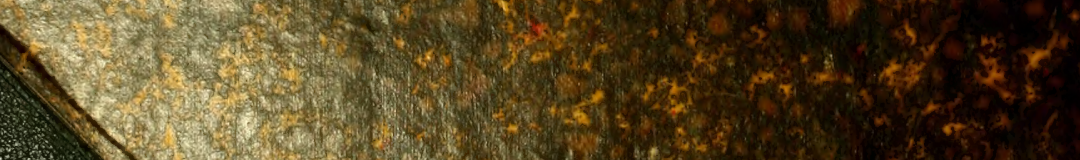

1.

tes 